




\section{EDUCATION AND THE HEREDITY SPECTRE}


"The bubble of heredity has been pricked." 


\section{EDUCATION AND THE}

\section{HEREDITY SPECTRE}

BY

F. H. HAYWARD,

D.Lit., M.A., B.Sc.

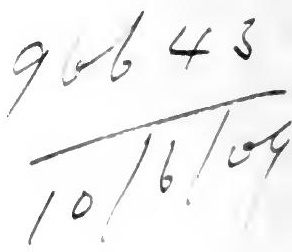

LoNDON :

WATTS \& CO.,

17, JOHNSON'S COURT, FLEET STREET, E.C.

1908 



\section{CONTENTS}

PAGE

Preface

CHAPTER

I.-The Plant Metapior and the Biometricians - I

II.-Soul-Plasticity and the Power of Ineas - - 13

III.-The Vinication of Herbart - - - . - - 27

IV.-Some Spechal Problems - - - - - 38

V.-Professor Adams's " Herbartian Psychology" - 50

VI.-Enter the Doctrine of Formal Training - - 70

VII.-Moral Instruction: Methods and Difficulties - 76

VIII.-Exit the Doctrine of Formal Training - - 106

IX.-Prejudices and Predictions - - - - - 116 APPBNDIX

I.-Some Notes on Heredity - - - - - $\quad$ - 133

(1) Terminology ; (2) "Nature" v. "Nurture" ;

(3) Mendelism; (4) What is truly inherited in man? (5) Myths and misunderstandings ; (6) The alleged transmission of parental acquirements

II.-Mr. Keatinge's Herbartianism - - - - 142 
Digitized by the Internet Archive in 2007 with funding from Microsoft Corporation 


\section{PREFACE}

THE argument of the following essay is identical with that of a series of lectures delivered at Scarborough during the summer of 1907. In the course of the following autumn and winter an outline of the same was given before several London audiences; and on one occasion the Chairman, a well-known educationist and county councillor, expressed the wish that it should be published. This, accordingly, has been done.

The least necessary, and probably the least satisfactory, of the following chapters is the fourth. No great stress need be laid upon it; the questions with which it deals are not likely to be solved for many years to come.

Chapters VI. and VIII. are important as dealing with the great educational superstition which passes in secondary schools as philosophy. Those people of " practical" tendencies who regard "theory" as incapable of influencing school work are invited to contemplate the influence of this dogma.

Chapters I., II., and III. will serve to indicate the important bearing of biological and sociological research upon education.

In Chapter IX. some general considerations are adduced.

Chapter VII. is obviously tentative, as, indeed, until schools and training-collegres have given a century of work to the present problem, all chapters dealing with actual methods of moral instruction must necessarily remain. At present there is hardly a place in Britain where public criticism lessons on literature or history-still less on "morals," in the narrower sense-are given; and where, in consequence, the teacher who has left 
college days behind him can judge of what is possible or desirable. We are all in the fog, and most of the affirmations commonly heard-and doubtless some of those confidently set forth in the present book-are simply instances of darkening counsel by words without knowledge.

Indeed, to show that the present essay, whatever else it may not be, is impartial, mention may be made of the fact that portions of it stand in absolute opposition to a luckless statement of five words to be found on page 6r of The Secret of Herbart.

On the controversial question of the relative merits of "direct" and "indirect" moral instruction the verdict of this chapter is unmistakable. If by "indirect moral instruction" is meant genuine instruction-or genuine "suggestion," to use $\mathrm{Mr}$. Keatinge's word-springing naturally out of an excellent and comprehensive curriculum, it is undoubtedly far better than anything more "specific" or "direct." The writer of these pages has never held any other opinion. As far back as 1902, in The Student's Herbart, the abstract objection to fenced-off lessons and the weakness of a purely negative morality were pointed out. The Secret of Herbart, too, is nothing but a plea for indirect moral instruction, called there by the name of "manysided interest." Herbart's own words could further be adduced: "The individuality must first be changed through widened interest...... before teachers can venture to think they will find it amenable to the general obligatory moral law "-a statement which means that "direct moral instruction" is ineffective apart from the possession of apperceptive resources by the child; that the "subjective " character needs a broad basis in the "objective."

The trouble is that, so long as the dogma of "formal training" and sundry other baseless delusions are all-powerful in England, indirect moral instruction will never get the opportunity it needs. "Diet, not doses," says Mr. Paton, cleverly and truly. But suppose "diet" is lacking, suppose the curriculum is deficient in the humanistic factor, the proposal of "doses" is not only 
inevitable but commendable. A man who is starving is grateful even for a cake of concentrated essence.

It is highly probable that ultimately nine-tenths of our moral instruction will be given indirectly-i.e., in the course of the ordinary curriculum; and, possibly, even the refractory tenth may be given in the same way. What is to be done in the meanwhile is a difficult question. It will neither be solved by prescribing "direct moral instruction," and then letting teachers muddle the subject unaided ; nor by prescribing " indirect moral instruction," and interpreting this in the sense of leaving things just as they are. The danger that direct moral instruction may become a dull, pedantic, inconsequent affirmation of moral saws is exactly balanced by the opposite danger, that indirect moral instruction may be identified with meaningless training.

The main contentions of the present essay are: (1) that the normal conscience is not a ready-made and unalterable "faculty," born good or born bad, as biometricians and others would almost imply, but that (2) moral instruction is necessary for its development, this instruction, whether "direct" or "indirect," being genuine and significant. If these two last terms could be constantly employed, the almost valueless antithesis of "direct" and "indirect" could be dropped.

The fifth chapter is the most important in the book. If critics of the present essay are able to undermine the standpoint of the distinguished educationist whose teaching is there summarised, most of the other chapters will fall to ruin at once. It is important that the public should recognise the fact that our most authoritative educational thinkers are divided into two parties upon the vital question of the possibility of characterforming. Neither the public nor the thinkers always realise the sharpness of the cleavage, perhaps because pedagogical formula are rarely taken more seriously than the distinctions drawn by the mediæval scholastics, or because mutual courtesy forbids the rival thinkers to make the embarrassing confession of their rivalry; what is thus unexpressed remains in a measure 
unrealised. But the fact remains that nine educationists out of ten affirm as error what the minority affirms to be educational truth. It is time that the antinomy should be at least recognised. The lightning of controversy is better than the murky stagnation of fog.

The present essay backs the minority, on the ground that the view they represent is more likely to help education onward than any rival view.

The Herbartians, who in England consist of some three or four harmless individuals of the male sex, but in the writings of their opponents loom forth as an army of seductive sirens, wooing the educational Ulysses to his ruin, have no esoteric opinions of their own at variance with the results of childstudy and brain physiology. They do not believe for a moment that ideas are self-existent entities, or that feeling and will are not implicit from the first in the soul, or that heredity and instinct are impotent. They do but believe that the best startingpoint for the educational thinker is the idea ; the most illuminative psychological formula, "apperception"; the best aim to be set immediately before the teacher, "many-sided interest"; the best ultimate aim, "character-forming." Voilà tout!

Indeed, such Herbartians as exist in England often feel profoundly sceptical when in the act of employing their own characteristic categories. Often and often they question whether perhaps, after all, the standpoint of Mr. Galton and Professor Pearson may not be essentially right; whether physical and biological forces may not rule the world; and whether even the best instruction is not impotent against the mighty atom or the wily chromosome. ${ }^{x}$ It is true, they cannot discover a weak link in the chain which joins ideas to character. ${ }^{2}$ It is true that the presentational mechanism, though working with different degrees of smoothness and energy owing to the various disturbing factors vaguely called by the name of "heredity," nevertheless

× See Appendix I.

${ }^{2}$ Ideas-apperception masses-apperceptive interest-volition. 
seems to work, after a fashion, with all normal men. Despite this, the Herbartians, feeling that their categories are too plausible to be true, struggle to get free from the verbal wrappings of their system, and to see the real educational world from which they have been withheld. And then, just at the moment when they have got a leg, or an arm, or a finger free, they discover - a curious thing !

This system will not leave men alone. Every friend and every critic who approaches too closely becomes immeshed in its palpitating fabric, the only difference being that the former is conscious of his immeshment and the latter is not. The controversialist narrates his objections to Herhartianism ; perhaps wins applause or preferment as a sane and sensible thinker; and then, sitting down to produce his magnum opus, finds himself unable to escape from the toils of the very system he is engaged in denouncing. What, then, is the use of the Herbartian seeking release from the fallacies that obsess him, when his only lucid opponents talk, think, and panegyrise Herbartianism? That they do it unconsciously is the very highest compliment that the system can receive.

How essentially right Herbartianism must be-right not necessarily in every detail, but in outline and outlook-if, whenever a really helpful and stimulating book comes from another camp, the factors it stresses are Herbartian factors, and the formula it uses are similar or identical with Herbartian formulæ! Such is the case with Mr. Keatinge's Suggestion in Education.

A preface is not the place to prove how akin to Herbartianism is Mr. Keatinge's doctrine of "suggestion." " Only one point need be mentioned, as bearing upon the controversy regarding moral education. The place of the dogma of "formal training" (a dogma absent from Mr. Keatinge's book, as it will, sooner or later, be absent from every serious book on education) is taken by a 
doctrine infinitely more helpful ; "stress," he says, " must be laid on the meaning of every idea that the school provides." " If this doctrine of meaning, significance, insight, apperception, or whatever we choose to call it, were once installed in place of the decaying fetish of "formal training," there would be no further controversy as to the respective merits of direct or indirect moral instruction. Indirect instruction would be the long-continued provision of materials that would ultimately enable meaning to be perceived or apperceived, and direct instruction would be the final summation, formulation, and extension of that meaning.

It is from no lack of courtesy or esteem that the opinions of several educationists are traversed in this book. Compliments to a genius like Mr. Bernard Shaw would be as grotesque as was Lord Frederick Verisopht's patronage of Shakespeare's "clayverness"; and in one of his flashes Mr. Shaw has uttered what may well be the motto of the present book-" The bubble of heredity has been pricked." But; seeing that in another epigram he has summed up the view that character is unalterable, this second epigram has been selected for criticism in these pages, for the reason that it appears representative of a more or less definite school of thought.

If this were a place for confessions, a personal debt owed to the helpful works of Professors Welton and Findlay might be adduced in proof of the fact that, though certain of their opinions-or their formulæ-are criticised in these pages, their services to educational thought are not forgotten. Mr. Skrine and $\mathrm{Mr}$. Paton represent the public school tradition at its besta tradition which, if supplemented by another factor, could not be much further improved upon for years to come. The writer has deliberately chosen men who were worth choosing, convinced that to choose lesser men would have been to spoil the argument of the essay. No doubt, if a reply were vouchsafed, it would be that one or more of these four educationists, and perhaps Mr. Shaw 
also, did not mean what is here imputed to them. That is the distressing fact about educational philosophy, in England more particularly. Expressions like "drawing out " and "training" are employed without any defined meaning. They do mischief; they bar the way to reform; they darken counsel; but when criticised they are said to mean something very different from what the critic asserts. The present essay will do good if it stimulates educationists to define what they mean by "drawing out," what they mean by "training," and what they mean by the "plant" metaphor, and sundry other items in their terminological armoury.

No apology seems needed from an educationist to the venerable author of Hereditary Genius for traversing his opinions. If Mr. Galton is essentially right, educational philosophy may at once admit its own pretensions to be fraudulent-Othello's occupation's gone. Though possibly the biometricians may in the end prove their case, any society in which their principles of human improvement are acted upon is so remote, not only in time, but in moral standpoint, from the present, that only to a man of Mr. Wells's genius is it even conceivable. Meanwhile let us exhaust the possibilities of education.

It is in the modest confidence that those possibilities have not yet been exhausted, or even adequately realised, that the present essay has been written. And a bold prediction is hazardedthat in years to come few people will be able to believe that there was need of the present argument at all, or that intelligent men could ever have imagined that phrases like "drawing out" or dogmas like "formal training" were adequate for educational guidance. Maybe, even those secondary masters who are to-day condemning moral instruction as something ludicrous or impossible will affirm, before many years have gone, that they never condemned real moral instruction, but only_-something else. What is it they condemn?

Meanwhile, "the Herbartians" feel their position acutely. Possessing-some of them, at any rate-" more zeal than 
philosophical knowledge" (in the opinion of Professor Darroch), " more enthusiasm than critical power" (in the opinion of Mr. Keatinge), they recognise that they are somehow wildly astray. But no one offers to help them to stagger safely into the true path of orthodoxy. They peruse the pages of the former writer -and remain stupidly unenlightened; they peruse the pages of the latter-and agree with almost everything he says. If Mr. Keatinge's standpoint is right, they, too, are right ; for they have been saying the same things as he, and in almost the same words.

It must be, as their critics assert, sheer lack of knowledge and critical power that prevents them from discovering where their categories are wrong. Subtle distinctions must lie beyond their mental grasp, and even their humble "zeal" and "enthusiasm" cannot compensate for such a lack.

Perhaps the present work may serve a useful purpose in attracting to the conflict some prince of educators who, feeling that "the Herbartians" have only hitherto been chastised mildly with whips, may resolve-though more in sorrow than in anger - to chastise them with scorpions. Indeed, he can do nothing better for education than to expose the blunders presumably lying latent in Chapter V. of this book. They seem to have deluded the writer of these pages, and they are doubtless deluding countless others. Such heresies are most tolerable, and not to be endured. When they have been exposed-and when the chair of education in London University has thereupon been declared vacant-education will gladly sit at the feet of the new Gamaliel. But just at the present moment it seems a remote incongruity to a mere Herbartian mind-lacking in critical power and philosophical knowledge-that young teachers should be set to learn a series of "Herbartian" doctrines which sane and sensible educationists unite in declaring to be somehow wrong. ${ }^{\mathrm{x}}$ A nation whose children are alleged to

I Professor Adams's Herbartian Psychology is prescribed for the Teachers' Certificate Examination of 1908. 
be capable of "drawing morals" for themselves with precision and vigour should be able to draw some embarrassing "morals" from that fact.

And the first moral is that if Professor Adams is broadly wrong in his teaching - if he is playing with false or dangerous categories-his book was the last that should have been prescribed for young teachers to study. Some other book-sounder, safer, duller-should have been chosen.

And the second moral is-But everyone can draw it for himself. And the third also. And one or two others that loom up in the distance.

F. H. H.

April, 1908 .

P.S.-The sincere thanks of the writer are due to his wife and also to Mr. W. J. Saunders for help in the correction of proofs and in other ways.

Still more does he wish to thank Dr. Kimmins, Chief Inspector of Schools, London County Council, for suggestions and advice. Perfect agreement on the questions raised is not here assumed; but if any elements of moderation and reasonableness are discoverable in the book, their existence is partly or mainly traceable to the influence of Dr. Kimmins. 



\section{EDUCATION AND THE HEREDITY SPECTRE:}

OR, THE PROBLEM OF MORAL INSTRUCTION.

\section{Chapter I.}

\section{THE PLANT METAPHOR \& THE BIOMETRICIANS}

No clear views are possible on the present subject so long as instruction in general is proclaimed to be the least important part of education. Three typical passages which seem to disparage it will be selected for criticism in these pages.

The first is a maxim of Mr. Bernard Shaw. Not the cleverest and falsest of them, "He who can, does; he who cannot, teaches," but another:-

"The vilest abortionist is he zoho attempts to mould a child's character." Character, presumably, cannot be "moulded." Man is what he is, and even Superman cannot be more.

Professor J. Welton holds that it is an "error" to think that "human life can be built up from without, and its form and tendency determined by an artificial arrangement by another of the ideas it is to assimilate." The present essay claims that it is no "error" at all.

An eminent representative of secondary education, Mr. J. H. Skrine, assures us that "imparting knowledge is not the teacher's business....... The educator has not to put something into his pupil, but to draw out from him what is in him." This essay attempts to show, on the other hand, that, if we must deal in metaphors, that of "putting in " is a better metaphor by far than that of "drawing out." 
The problem may be stated in yet another form.

In the year I804 Herbart faced the question whether the analogy which now passes current as sound, helpful, and stimulating was not, in truth, erroneous or misleading. Is man, educationally considered, like a "plant"? I For years the metaphor had flitted seductively before men's minds. Years were yet to pass before Froebel, in the crowning moment of his life, was to seize upon it with triumph and delight; the school should be a "kindergarten "-a "garden" of children. Strange that in all that time only one thinker seems to have deliberately searched into the recesses of the metaphor!

On any theory of existence, monkeys are more "human" than plants; and yet the suggestion of man's kinship with the ape awakened furious opposition half a century ago. Kinship with the plant is far more extraordinary; of all living creatures, this seems farthest removed from man. An intellect like Herbart's was not likely to let such a metaphor as this of the "plant" pass unchallenged. For mischief may lurk in metaphors.

What was-what is-the point at issue? The future form of a plant is admittedly determined in advance. True, there are "variations" and "mutations," the laws of which we are likely, sooner or later, to know; true, also, even plants are plastic, in a measure, to environmental influences. ${ }^{2}$ Broadly, however, we may say that the fate of a plant is fixed by the nature of the germ from which it springs. "Do men gather grapes of thorns, or figs of thistles?"

If the same law holds equally good of human beings as of plants, then, indeed, all attempts to "form character"

I "We talk of forming a character...... as though the teacher had...... control over a......plastic material. The metaphor of the......flower is more apt...... The educator must deal with his human seeds as he finds them." - The President of Magdalen, quoted by Mr. Keatinge.

= See Appendix I. 
will be the deeds of a "vile abortionist." We shall have to admit that human life cannot have its "form and tendency determined by an artificial arrangement of ideas"; and that the teacher must think mainly or solely of doing obsequious homage to the predetermined characteristics of the child, "drawing" these out, rather than conferring knowledge or imposing ideals of his own. Reverently, albeit somewhat impotently, the teacher will follow the self-determined unfolding of the organism committed to his care. His work will be "passive, observant, protective." Buddhist teaching will be unable to make Buddhists, Catholic teaching to make Catholics, atheistical teaching to make Atheists, socialistic teaching to make Socialists ; for pedagogy says so. Above all, moral teaching, direct or indirect, will be ineffective. Plants are singularly unresponsive to it.

If, indeed, the plant metaphor is even approximately true, the giving of information, knowledge, or ideas to the child must be recognised as a subsidiary, incidental, and perhaps pernicious, process. Such things may rankly inflate or subtly narcotise, but they cannot shape the intractable organism. Hence the supposed significance of Thring's exhortation, "Smash up the knowledge idol"; of Mr. Skrine's dictum, "Imparting knowledge is not the teacher's business"; and of scores of other maxims circulating in the educational world, and producing bewilderment and scepticism.

But, asked Herbart, "Does a human being bring with him into the rvorld his future shape, or does he not? In respect to his body he doublless does; but that is not our question. We speak of the mind, the character, the interest, the entire disposition. ${ }^{\mathrm{x}}$ Here we meet...... a host of opinions. A man's temperament is bestowed by nature, say some. Naturally, man is good, say others. But, by original sin, 
' born evil' is added by a third group. It is education that makes everything of him, is the opinion of a fourth judge. He makes, posits, and determines himself, exclaim the latest systems."

Herbart will be led astray by no analogy whatever. That the bodily shape is substantially determined in advance is no proof that the mental and moral shape is similarly determined. The mind, compared with the body, may be immeasurably plastic, and thus the whole philosophy of "drawing out" may be educationally false, or at any rate misleading. The old-fashioned metaphor of the tabula rasa, the old-fashioned philosophy of the impressionability of man, may be more true than the newfashioned metaphor of the plant, the new-fashioned philosophy of the unchangeableness of character. Environment and education may be well-nigh omnipotent, in shape-giving power, when compared with heredity. Such is Herbart's first thought. If he was right, we may bid farewell to views of education which depress and paralyse and mystify.

Among the preachers of barren educational creeds are those who form the last-named class in Herbart's list of theorists. Man, they tell us, "makes, posits, and determines himself"; the teacher, therefore, cannot touch the child's inner soul, cannot, by any efficiency of leverage, move his will. Iago, to be sure, despite all mystic "selfdetermination" on Othello's part, could immesh and ruin the noblest of men, playing upon his will as upon an instrument. Fagin, too, could train and instruct an academy of youthful thieves. ${ }^{x}$ But such things are impossible in the sacred cause of Virtue. The Devil alone has the educational secret in his possession. He can reach the will, but education cannot.

Readers may think it gratuitous that at the outset of his

${ }^{x}$ Examples borrowed from Professor Adams. 
work Herbart should have assailed this view. Why not call the will a "mystery," and pass on? Why not confess, with an able theologian of the present day, that "when we have traced an occurrence to the intervention of the human will, we are at once content. It is fully accounted for. We know not merely how it began, but why, and have therefore reached its absolute beginning." I Why not, with Kant, place the will in a region inaccessible, whence it may issue when it chooses, but whither we, with all our educational devices, can never penetrate? For a very good reason. Though the door be closed to the teacher, it will be kept open for other agents who will still claim to reach and influence the inaccessible. ${ }^{2}$ Herbart was the first man in history to see that the peril for education lay in a mystic and slippery theory of the will; he saw this when a young man of twenty-eight, and he still urged it when bordering on three-score. Unless the rvill is accessible to the teacher's hands and plastic to his touch, the teacher's work is relatively unimportant.

Herbart, then, rejects the view that the will is a miracle which only other miracles can meet on equal terms. Such a view is a "mere dream, which psychology is bound to declare a delusion, ethics a misunderstanding, and metaphysics an absolute impossibility." And yet, if man "brings with him into the world his future shape," education remains as powerless as ever. We may have got rid of an inaccessible will, but we are faced by an unalterable individuality. Does the mind follow the law of the body? Are a man's "character, interest, and entire disposition" born with him? "Does the principle of a man's education lie in himself in the sense in which the whole shape of a plant lies prepared in its germ, or does the construction of

Rev. J. R. Illingworth-Divine Immanence.

2 "I do not attach much (comparative) importance to the teaching of arithmetic, geography, or other (secular) subjects."-The Bishop of Clifton, 1902. 
his individuality originate in the courte of his life only?" Is a man's character the result of heredity or of environment? Or if of both, which factor is the predominant one?

To this a number of "biometrical" thinkers, led by $\mathrm{Mr}$. Francis Galton and Professor Karl Pearson, answer "Heredity"; and much educational thought, as we have seen, is dyed or tinged with the same belief. The soul, from birth or from before birth, has its pre-destined form, its fixed potentialities ; education can do little to shape the form, and nothing to increase the potentialities. The "vilest abortionist" (because the most hopelessly ineffective of abortionists) will be he who attempts to "mould a child's character." It will be an "error" to think that "human life can be built up from without," etc. ; "the educator" will not have to "put something into the pupil," etc.

Doubtless the authors of these words could so qualify and explain them as apparently to render them innocuous and plausible. It is questionable, indeed, whether panegyrists of "drawing out" always realise or approve the implications of their doctrine. But Professor Karl Pearson is under no delusion. He rends the veil of academic decency which hides the grisly spectre of heredity :-

"The relative gain from education depends to a surprising degree on the raw material.......Ability may be fostered by home environment and by provision of good schools and well-equipped institutions for research; but ......its origin, like health and muscle, is deeper down than these things......It is bred, not created. It is the stock itself that makes its home environment...... Intelligence can be aided and trained, but no training or education can create it. It must be bred."

The reader should learn, too, that not only his ability, but his morals-his "geniality and probity"-depend on his "stock." "We inherit our parents' tempers, conscientiousness, shyness......even as we inherit their stature, 
forearm, and span." Moreover, the "regression line" . is the same for "vivacity, assertiveness, introspection, and temper," as for "handwriting and general ability," for "head-measurements and body-lengths." "If man's physical characters are inherited even as those of the horse, the greyhound, or the water-flea, zohat reason is there for demanding a special evolution for man's mental and moral side $\mathrm{P}^{2}$ If the relation of the psychical characters to the physical is established, what is its lesson?"

The lesson is that the only way in which our race can maintain itself in mental and moral prosperity is by a process of selective breeding. "The mentally better stock of the nation is not reproducing itself at the same rate as of old; the less able and the less energetic are more fertile than the better stocks..... The only remedy, if one is possible at all, is to alter the relative fertility of the good and bad stocks in the community......The intellectual classes...... have ceased to give us in due proportion the men wanted to carry on the ever-growing work of our Empire, to battle in the fore rank of the ever-intensified struggle of nations. The remedy lies first in getting the intellectual section of our nation to realise that intelligence can be aided and be trained, but that no training or education can create it. It must be bred." 3

And now, between this depressing passage and another equally depressing from Mr. Galton's earliest work, may be intercalated one from Herbart's speech at Bremen-a ray of sunlight between two belts of dungeon gloom :-

"We find in animals instincts. They must fulfil the work of their nature...... Much more consistent is the internal action of a plant. But much more inconsistent is the action of man......He is impelled by the mechanism

3 An important statistical relation worked out by Professor Pearson to show the influence of heredity.

2 Italics ours.

3 Pearson, Huxley Memorial Lecture. 
produced by the presentations or ideas ${ }^{x}$ that he has apperceived. These presentations themselves are forces which check and aid each other. They constitute powers which elevate and throw down, oppress and liberate one another, and which, by this very conflict, get into all those conditions which we call by a name far too general, far too indefinite-will...... Do not let us forget for a moment that this machine is exclusively built of presentations or ideas. ......Man wills only presentations, and knows only presentations......Education will, therefore, endeavour to nourish man by presentations......It by no means consists merely in supervising and tending, like our gardening art, that makes plants its care...... In the case of plants the one essential point is to bring about favourable and keep off unfavourable circumstances, and to have rain and warmth, soil and atmosphere well suited to each kind of plant. Man, on the contrary, requiring no determinate climate, but making his way in any one, capable of becoming-_"

"Becoming nothing but what is pre-destined by his origin and 'stock'?" "Becoming nothing but what is already latent within him in form, and ready to be 'drawn out'?" Use such expressions if you will, but note their ultimate implications in the paralysing doctrines of Karl Pearson and Francis Galton. Herbart's words are more encouraging :-

"Man, capable of becoming, as you will, a wild animal or personified reason, and formed incessantly by circumstances, needs an art which shall build him up and construct him in order that he may receive the form that is right." 2

I "Presentation" and "idea" will be used interchangeably for "Vorstellung."

2 Herbart's Minor Pedagogical Works (Appleton). Italics ours. Compare this passage with Professor Adams's :- "Given the same first-class mind, we may turn out an Artful Dodger or a James Watt ; given the same third-rate mind, and we may develop it into a Bill Sikes or a more than respectable artisan." Morals appear here to 
And now back into the gloom. For a brief moment we have dreamt that the educator may reach his pupil's will through the mechanism of ideas with which that will is somehow linked. We have fondly thought that the pupil may " receive the form that is right," not develop to a form already pre-destined in the structure of the germ. Our desire has been that he become a cultured gentleman, fearless, truth-seeking, and intelligent. Alas, Mr. Galton will tell us that culture, gentleness, fearlessness, truth-seeking, and intelligence have been, in large measure, weeded out from the human stock, partly by the rule of celibacy, partly by persecution, for both of which the Church of the Middle Ages was responsible. Attend, reader, to the story of your ancestry; and if you should chance to possess any rudiments of culture, gentleness, fearlessness, truth-seeking, and intelligence, think on what you might have been had not your ancestry been "brutalised and demoralised" :-

The long period of the dark ages under which Europe has lain is due, I believe, in a very considerable degree, to the celibacy enjoined by religious orders on their votaries. Whenever a man or woman was possessed of a gentle nature that fitted him or her to deeds of charity, to meditation, to literature, or to art, the social condition of the time was such that they had no refuge elsewhere than in the bosom of the Church. But the Church chose to preach and exact celibacy. The consequence was that these gentle natures had no continuance; and thus, by a policy so singularly unwise and suicidal that I am hardly able to speak of it without impatience, the Church brutalised the breed of our forefathers. She acted precisely as if she had aimed at selecting the rudest portion of the community to be alone the parents of future generations. She practised the arts which breeders would use who aimed at creating ferocious, currish, and stupid natures. No wonder that club law prevailed for centuries over Europe; the wonder rather is that

be almost entirely a matter of environment. We shall presently learn that they are. 
enough good remained in the veins of Europeans to enable their race to rise to its present very moderate level of natural morality.......

The policy of the religious world in Europe was exerted in another direction, with hardly less cruel effect on the nature of future generations, by means of persecutions which brought thousands of the foremost thinkers and men of political aptitudes to the scaffold, or imprisoned them during a large part of their manhood, or drove them as emigrants into other lands. In every one of these cases the check upon their leaving issue was very considerable. Hence the Church, having first captured all the gentle natures and condemned them to celibacy, made another sweep of her huge nets, this time fishing in stirring waters, to catch those who were the most fearless, truth-seeking, and intelligent in their modes of thought, and therefore the most suitable parents of a high civilisation, and put a strong check, if not a direct stop, to their progeny. Those she reserved on these occasions to breed the generations of the future were the servile, the indifferent, and, again, the stupid. Thus, as she-to repeat my expression-brutalised human nature by her system of celibacy applied to the gentle, she demoralised it by her system of persecution of the intelligent, the sincere, and the free. It is enough to make the blood boil to think of the blind folly that has caused the foremost nations of struggling humanity to be the heirs of such hateful ancestry, and that has so bred our instincts as to keep them in an unnecessarily long-continued antagonism with the essential requirements of a steadily-advancing civilisation. In consequence of this inbred imperfection of our natures, in respect to the conditions under which we have to live, we are, even now, almost as much harassed by the sense of moral incapacity and sin as were the early converts from barbarism; and we steep ourselves in half-unconscious self-deception and hypocrisy as a partial refuge from its insistence. Our avowed creeds remain at variance with our real rules of conduct, and we lead a dual life of barren religious sentimentalism and gross materialistic habitudes. ${ }^{1}$ 
The view is depressing. The virtues of life seem to be but accidental "variations," like the colour of an animal's coat. If, as among the bears of northern regions, the colour should vary in the direction of whiteness, thus enabling the animal to be comparatively unseen by its prey amid the Polar snows, increasing whiteness will mark the Polar race, for cubs born with darker coats will have but small chance of survival, and therefore of propagating offspring. So, too, if an accidental variation in the direction of virtuous qualities should fail of permanence by the establishment of celibacy or persecution, these qualities will tend to extinction. The bear race will be gradually deprived of its whiteness, the human race of its virtue, until the time, presumably, when other variations in the black or the virtuous directions occur.

But doubts arise. These virtuous variations towards culture, gentleness, ${ }^{\mathrm{I}}$ fearlessness, and so forth, how did they arise in the first instance? By what means, too, did the Church maintain its power over the minds of men, power so great that celibacy and persecution were accepted institutions? Was it that the priesthood consisted of men who, by some extraordinary force of character (handed on from father to son) succeeded in maintaining the ill-starred supremacy of their Church? The question needs only to be asked to be answered; priestly qualities were not handed down by heredity, for priests were celibates. Indeed, the remarkable uniformity in type of Catholic clergy throughout the ages and races of mankinduniformity at least in moral standpoints and ideals-has

"As to "gentleness" (humanity), expressly referred to by Mr. Galton, Darwin says cautiously : "I doubt whether humanity is a natural or innate quality."-Life and Letters. Moreover, teachers who have worked for thirty or forty years in London are convinced that there is far more "humanity" among the populace now than when they began to teach. Does anyone claim for a moment that this result is due to any process of selection? Has the "stock" substantially changed (for the better) in thirty years? 
been adduced to prove that there is a kind of heredity of which Mr. Galton takes too small account, "social heredity." $x$

Our main question is, whether "variations" in the direction of virtue are the chief or only cause of the moral progress of the world; in other words, whether the laws of moral evolution are the same as the laws of biological evolution exemplified by the Polar bear or the plant.

I Ritchie-Darwinism and Politics. Possibly, however, $\mathrm{Mr}$. Galton would reply that the clergy were already a "selected" class; that men of independent minds would avoid becoming priests. 


\section{Chapter II.}

\section{SOUL-PLASTICITY AND THE POWER OF IDEAS}

That in very remote ages of human development some process of moral selection took place may be true enough. $A$ race that possessed the elements of social solidarity would survive at the expense of a race devoid of those elements. A race whose mothers possessed motherliness would survive at the expense of a race whose mothers were careless of their offspring. Without the existence of social virtues in their parents, the young would perish, carrying with them to their graves the strain of the anti-social.

But to maintain that this principle still regulates the supply of human virtue seems the extreme of error. Once man had attained some measure of solidarity ; once he had accumulated a social tradition; once a moral ideal had definitely entered the world, there was little or no further need for preservation of social and destruction of anti-social varieties. "Stock" and "heredity" came to count less and less ; "environment" and "education" came to count more and more. Even children born of non-social and selfish parents might grow up social and virtuous by the impress of ideals. Professor Pearson asks "what reason" there is for demanding "a special evolution for man's mental and moral side." No reason, so long as we imagine that plant metaphors are significant for human education, or Mendelian studies in plant reproduction ${ }^{x}$ significant for human heredity. No reason, so long as we seek to study human evolution through the medium of "the horse, the greyhound, and the water-flea." But if 
our concern is with the evolution of man as man, we shall have to admit a "special evolution" of his mental, and especially his moral, side. Exactly what Professor Pearson doubts or denies is exactly what evolutionary philosophy demands. For suppose that, after all, man-even physically -is one of the least variable of all animal forms. ${ }^{\mathrm{I}}$ Suppose that man has fewer or, at any rate, less definite hereditary instincts than any other highly developed creature under the sun. Suppose that his evolution has taken the final and unique form of increased plasticity, suggestibility, educability. Where, then, would be the significance of Mr. Bernard Shaw's protest against "moulding character"; Professor Welton's denial of a "building up" process in mental life; Mr. Skrine's advocacy of "drawing out;" Professor Pearson's appeal to sub-human analogies; and Mr. Galton's theory of variational virtues? They would at once lose nine-tenths of their significance.

To assert that such eminent men as the last two have wholly misinterpreted the facts of moral evolution is a bold step. Nevertheless, Rome did not, to all appearances, "brutalise and demoralise" European life in the way that Mr. Galton thinks. She robbed Europe not so much of stock as of ideas. Her persecutions debased not by preventing heretics from begetting children of heretical heredity, but (mainly at least) by stopping the mouths of heretical men, and thus preventing the circulation of stimulating knowledge. If Spain is at this day "superstitious and unintelligent," as Mr. Galton asserts, the reason is not that, having been "drained of Freethinkers at the rate of I, 000 persons annually for the three centuries between I47I and I78I,", she is now paying "a heavy penalty in the deterioration of her breed." The reason is that those 340,000 burnt and imprisoned Spaniards were

I The first of these suppositions is more doubtful than the second and the second than the third. Authorities are divided. 
prevented from contributing to the national traditions; prevented from adding their ideas to the mental and moral atmosphere of Spain. For "fearlessness, truth-seeking, and intelligence" are probably handed down not so much by physical as by social heredity, and the same is true of "servility, indifference, and stupidity." Rome's warfare against books was more effective than her warfare against their writers.

If by some miracle the intellectual atmosphere of Spain could be changed, there is every likelihood that the real or supposed debasement of the Spanish stock would be found to count for little ; or that, if an interchange of newly-born children were effected between England and Spain, the new generation would grow up with the "fearlessness, truthseeking, and intelligence," or with the "servility, indifference, and stupidity" of their new parents.

For let us follow Mr. Galton's instances a little further. France, too, has had her persecutions. "In the seventeenth century three or four hundred thousand Protestants perished in prison, at the galleys, in their attempts to escape, or on the scaffold, and an equal number emigrated. Mr. Smiles......has traced the influence of these and of the Flemish emigrants upon England, and shows clearly that she owes to them almost all her industrial arts and very much of the most valuable life-blood of her modern race." s France, then, was depleted of her most intellectual and energetic members. Nevertheless, of all nations of Europe the French are at this day, and have been for over a century, the most sceptical race on earth. How is this to be explained?

Solely by the power of ideas. The Huguenots were expelled, but a school of free-thinking writers arose, so influential, so European, that they established a sceptical tradition in France, more powerful than the Catholic 
tradition which it opposed. The grandchildren of the men who expelled the Huguenots were murdering or expelling Catholic priests at the time of the Revolution. Observers tell us that this sceptical tradition is so omnipotent in France that the possibility of any form of theism, of any intelligent reverence for the Bible, even a literary reverence, never crosses the mind of the average Frenchman.

How comes it, indeed, that in England there exists a certain reverence for the Bible? Is it traceable to anything in the heredity of the race, or is it not rather a part of our social traditions, our stock of ideas? If some practical scientist with the imagination of $\mathrm{Mr}$. Wells could invent an invisible vapour which, diffused through the atmosphere, would destroy all memories of Biblical phrases stored in the minds of Englishmen; if, at the same time, all Bibles were burnt and all Biblical references in books were obliterated, the English race thereupon would become a different race from what it is-different in standards, in prejudices, in perception of meanings ; it would be deaf to a thousand appeals that now move it, blind to a thousand problems that now face it. The English reverence for the Bible is all too unintelligent, but no English educationist who compares England with France from the standpoint of ideals will have any feeling but one of patriotic gratitude that his is the land where this reverence prevails. Without a stock of ennobling ideas-Homeric ideas in Greece, Bushido ideas in Japan, or Biblical ideas in England-a nation is poor indeed. It is such things as these that count, and, compared with them, the slow and dubious influences of heredity are but as the influences upon morals of the spots in the sun. ${ }^{x}$

It is only in the light of the doctrines of apperception ${ }^{2}$

I Such an influence as this last was worked out plausibly by the late Professor Jevons.

${ }^{2}$ Apperception-the process of interpreting a new fact or expericnce in the light of past acquirements or experience. The term is 
and interest that the full significance of the words italicised in the passage about to be quoted can be seen. It is only, indeed, in the light of those doctrines that the reverent scepticism of men like Matthew Arnold, their solicitude that the Bible should be known and loved even by unbelievers, are intelligible at all. Such things are not only impossible, but inconceivable, in France. In that country, as Mr. Brereton points out, ${ }^{2}$ the word "reason" is the one to conjure with, possessing, as it does, a richness of suggestion-a power of apperceptive appeal-unintelligible to us.

"Only one literature there is, one great literature, for which the people have had a preparation-the literature of the Bible. However far they may be from having a complete preparation for it, they have some ; and it is the only great literature for which they have any. Their bringing up, what they have heard and talked of since they were born, have given them no sort of conversance with the forms, fashions, notions, wordings, allusions of literature having its source in Greece and Rome ; but they have given them a good deal of conversance with the forms, fashions, notions, roordings, allusions of the Bible. Zion and Babylon are their Athens and Rome, their Ida and Olympus are Tabor and Hermon, Sharon is their Tempe : these and the like Bible names can reach their imagination, kindle trains of thought and remembrance in them." 3

Such things as these are largely negligible in "biometrical" philosophy. That old Biblical names and narratives still arouse apperceptive echoes in the minds of

a wide one, and covers all grades of perception and comprehension ; interest is connected with apperception. See the writer's Secret of Herbart.

- Literature and Dogma, A Bible Reading for Schools, etc.

a Journal of Education, Feb. 1908.

3 A Bible Reading for Schools, The Great Prophecy of Israel's Restoration. 
Englishmen, that such interest has incalculable moral, cultural, and spiritual significance, are facts that stand outside the new science of eugenics. Yet far more important than the supposed heredity of a nation is the circle of thought, the atmosphere of ideas, the culture-inheritance into which the individuals of that nation are born. Even virtues like "prudence," in which the factor of temperament may play some part, seem mainly the result of these.

Mr. Galton, however, dissents. Prudence and imprudence are innate.

"I trust the reader will realise the heavy doom which figures pronounce against all sub-sections of prolific races in which it is the custom to put off marriage until middle age. It is a maxim of Malthus that the period of marriage ought to be delayed......If this doctrine influenced all classes alike, I should have nothing to say about it here......but as it is put forward as a rule of conduct for the prudent part of mankind to follow, whilst the imprudent are necessarily left free to disregard it, I have no hesitation in saying that it is a most pernicious rule of conduct in its bearing on the race. Its effect would be such as to cause the race of the prudent to fall, after a few centuries, into an almost incredible inferiority of numbers to that of the imprudent ; and it is, therefore, calculated to bring utter ruin upon the breed of any country where the doctrine prevailed." I

It is somewhat significant that "doctrines" can "prevail," even on our writer's confession. But if "doctrines" can "prevail" at all-as is implied in the fact that Professor Pearson and Mr. Galton, instead of assassinating men of inferior "stock," are attempting to influence public opinion on these weighty matters-then it is possible that, by means of educational agencies, doctrines can be made to influence men still more powerfully in the future than in the past. Indeed, there are reasons for believing 
that this very virtue of "prudence" is an example of such influence.

For we are told that in travelling through Ireland or Switzerland the Catholic or Protestant creed of the inhabitants is at once revealed by the appearance of the towns and villages passed, industry and prudence marking in unmistakable characters the sway of Protestantism. Supposing the facts to be as stated, an explanation by racial heredity seems far less convincing than one by social heredity. "Prudence" seems based on ideas and ideals of conduct. It happens to be a virtue of secondary importance to Catholics.

"What is heinous in the world is often regarded patiently by the Church, and what is horrible and ruinous in the judgment of the Church may fail to exclude a man from the best society of the world. The world......cannot avoid thinking very contemptuously of fruits which are different from those which it makes the standard and token of moral excellence in its own code of right and wrong...... The Church fulfils a number of secondary ends, and is the means of numberless temporal blessings to any nation which receives her. (But)......she is not to be estimated and measured by such effects......Judge of her fruit by her principles and her object......not by those of her enemies. ...... She goes forth on the one errand of healing the diseases of the soul...... She regards this world and all that is in it as a mere shadow, as dust and ashes, compared with the value of one single soul...... The Church aims at three special virtues......faith, purity, and charity, for two of which the world cares little or nothing. The world, on the other hand, puts in the foremost place, in some states of society, certain heroic qualities; in others, certain virtues of a political or mercantile character." 1

Prudence and imprudence, then, are, in some measure at

'Newman-The Social State of Catholic Countries No Prejudice to the Sanctity of the Church. 
least, the results of education. They spring mainly from men's views of the meaning of life. If the saving of the soul through the virtues of faith, purity, and charity is the supreme concern of our earthly pilgrimage, "prudence" may well take a back place, and the more or less thriftless Catholic who, in Newman's belief, is "immeasurably more tender and gentle and angelic" than the Protestant, is to be praised rather than blamed. The children of this world may prudentially be "wiser" than the Catholic "children of light." But if, on the other hand, the sturdy and straightforward performance of life's civic and mercantile duties, perhaps entirely apart from "faith," ought to be a prominent element in man's ideals of duty, then the Protestant Philistine, though unpicturesque and far from "angelic," is nevertheless treading not unworthily the stage of existence.

This notion that definite virtues are innate, not acquiredproducts of heredity instead of environment and education -is fatal to every dream of progress. Until refuted, it must work havoc with our hopes and methods. "Virtue," indeed, "cannot be taught" if virtues, like vices, are born with us. Fortunately, however, some recent evidence, together with a mass of biological opinion, seems decisive to the contrary.

The evidence is supplied by Dr. Barnardo's institution. If imprudence is ingrained in any human beings, surely the "stock" of the children who have been rescued from the streets of London must carry a double dose of the hereditary taint. These castaways - themselves the living fruit and witness of their parents' glaring "imprudence"-have to the extent of ninety-eight per cent. become respectable citizens, and a similar result (ninety-seven per cent.) has been obtained in the city of Glasgow. Heredity, in the sense of hereditary "imprudence," seems beaten all along the line.

At this point something should be said upon the 
readiness of men to explain by heredity what is otherwise caused. Whenever a human being shows a bias or proclivity which we, poor dabblers in the laws of psychology, cannot yet account for by influence from without, we attribute it to heredity. If one nation is "fickle and frivolous," another "brave and enterprising," a third "phlegmatic and philosophic," we explain the difference by race. If one sex has a greater love of dress than the other, we at once assume that the difference is inborn and not acquired. In nine cases out of ten we are probably wrong. We are being deceived by the undoubted facts of animal and physical heredity-facts like the inheritance of hair colour and eye colour. We think that what is true of such inheritance is true of all inheritance, and that even moral qualities are handed down through the medium of germ-cells. We forget, or perhaps we have never learned, that as man's mind is the most plastic organ in the world, the most imitative and receptive, the very qualities which seem the most obviously inherited may be the most certainly acquired. In a sense, heredity is even here supreme, for we inherit a plastic brain ; in another sense, heredity is almost negligible, for inherited plasticity is the very opposite of an inherited character-type

Dogmatically stated, the following seems the lesson of evolutionary philosophy:-As soon as man's brain began to be the decisive factor in his development, heredity and natural selection ceased to operate in their old ways. Not the being who was possessed of fixed and perfected instincts, but the being with few instincts and much power of acquirement-from his own experiences and the instruction of others-was now the favourite of nature. How the first variation in this direction came to occur-whether, through increased use of the hand, itself the result of the new posture, there was a general or specific development of the brain, and more especially of the speech centre in the brain, or whether, as Mr. Wallace would suggest, 
some mysterious "influx" occurred-this we can hardly determine. But it is clear that a time came when man's best legacy to his offspring was a plastic rather than a rigid brain, one that was capable of learning much rather than one whose faculties and instincts were determined from the first. The invention and establishment of language kept pace with this change, and did much to hasten it, for language may take the place of heredity and render it increasingly insignificant. Other factors doubtless co-operated in this process; above all, the lengthening of the period during which the child remained immature, and, therefore, impressionable.

The higher evolution of the race, then, has stripped man of definite instincts, leaving instincts which, with scarcely any exceptions, are so indefinite, so dirigible, as to differ almost in kind from those of the animal world. It has largely stripped him, too, of psychical variations, or, rather, has endowed him with a plasticity so great that these variations seem almost negligible in comparison with the possibilities of acquisition. Man has received at Nature's hands her last and strangest gift-a mind preeminently vacuous, receptive, and capacious. Endowed with such a mind as this, empty and hungry, he is now an "Animal Run to Brain "- "Nature's Insurgent Son." All analogies, therefore, based on the belief that what is distinctive of plant or animal is necessarily distinctive of him are analogies which, unless relative to his merely physical organism, are likely or certain to deceive. Yet such analogies are regarded at this moment as the latest word of pedagogical wisdom.

Some biologists go so far as to assert that not only suggestion but even genuine imitation is absent from the animal world. Certain it is that the animal's instincts carry it forward to its fate ; while in the case of man a new system of structures, based on experience and teaching, and 
rendered possible by his enormous power of memory, may profoundly modify his hereditary equipment.

Quotations seem the only way in which can be shown the conflict between academic concepts of education and the concepts of biology and sociology.

"The power of building up appropriate cerebral mechanism in response to individual experience, or what may be called educability, is the quality which distinguishes the larger cerebrum, and is that which has led to its selection, survival, and further increase in volume...... Educability can be transmitted-it is a congenital character; but the results of education cannot be transmitted......To the educable animal the less there is of specialised mechanism transmitted by heredity the better. The loss of instinct is what permits and necessitates the education of the receptive brain." I

"The theory of epigenesis has practically been established...... The majority of naturalists hold that growth of the higher life is not directly due to the latent qualities of ancestors, but is the result of new acquirements conditioned by extended experiences...... The progress which mankind is making still in its onward march......is due to the lessons of life, and not to the mysterious potencies of primordial germs...... If the doctrine of epigenesis be true, we must insist that those features which constitute the manhood of man are not contained in a latent form in his brute ancestors, but they are a new acquisition, which comes from without, not from within." 2

"Civilisation," says a third writer on sociology, "is the sum of those contrivances which enable human beings to advance independently of (biological) heredity." 3

"The plain, simple rules which govern the descent of animals cannot apply to that of man.......Moral training is

- Ray Lankester, The Kingdom of Man.

2 Paul Carus, The Rise of Man.

3 Ritchie, Darwinism and Politics. 
no more an essential part of (these) germinal cells than good manners; nor is a cultured taste more certain to be passed on to the next generation than a fine knowledge of the flavour of tea...... What is usually meant by heredity is something quite different, is what should be included under the head of effects of nutrition......As a matter of essential construction men are all very much alike..... for they must have had the same evolution..... The child is so easily influenced......that, unless there is a fixed and constant plan of action which is designed to fashion him in a certain manner, his final condition will be settled by a ragged combination of chance influences." $x$

Darwin himself - the very prophet of natural selectiondoubted gravely whether "selection" had much significance in moral matters. "Moral qualities are advanced, either directly or indirectly, much more through the effects of habit, the reasoning powers, instruction, religion, etc., than through natural selection, though to the latter agency may be safely attributed the social instincts which afforded the basis for the development of the moral sense." 2 In other words, though selection had something to do with the first beginnings of moral and social life, just as it had something to do with the whiteness of the Polar bear, new elements, distinctive of man, subsequently came on the scene, and became mainly responsible for his fuller growth.

And the co-discoverer of natural selection holds the same view. "The higher mental or spiritual nature of man is not the mere animal nature advanced through survival of the fittest." 3

"Even if we admit," says Dr. Stanley Hall, "that the rudiments of all the chief characteristics possessed by the species lie dormant in the egg, this does not compel us to infer that there is no inherited congenital indefiniteness, to

I Oppenheim, The Development of the Child.

2 Descent of Man.

3 A. R. Wallace, Fortnightly, Jan., 1908. 
say that all is pre-determined, that there are no latent energies to be not only set off, but guided by stimulation. ......All we need to assume is that there are neo-atavistic factors, and that the later part of each individual life is more characterised by the evolution of acquired qualities." $\mathrm{s}$ "Conscience," says the same great educationist, "is the most complex and, perhaps, the most educable of all our so-called faculties." Consequently, though "moulding a child's character" may seem an act of "abortion" to $\mathrm{Mr}$. Bernard Shaw, "conscience-building" through "carefully arranged (school) talks, with copious illustrations from history and literature," ${ }^{2}$ seems an obvious need of the age to Dr. Stanley Hall.

In sum, what Professor Pearson, armed with Occam's razor, challenges as improbable or absurd-that there has been a "special evolution" of man's mental and moral side-is precisely what biology asserts. A nameless revolution occurred long ago in the realm of human life. Heredity, after exalting plasticity to premier place in the state, found itself ousted by its own deputy.

By the acceptance of this view, much that would otherwise appear hopelessly hostile to the concepts of science is seen to be harmonious with them. Wallace's claim of a semi- or pseudo-supernatural origin for musical and mathematical 3 talent in the evolution of the race; Herbart's illuminating view that "mankind continuously educates itself through the circle of thought which it begets"; Wundt's contention that mental and moral energy, unlike physical, obeys no law of "conservation," but may go on increasing and complicating indefinitely; the stubbornly-

Adolescence.

2 Youth.

3 The savage is supposed to be unable to count beyond five, or thereabouts; but the truth is he lacks the traditional knowledge and terminology of mathematics, not mathematical faculty. Place him in a mathematical atmosphere, and he can count and calculate with the rest. Heredity has little to do with it - "social heredity" everything. 


\section{SOUL-PLASTICITY AND POWER OF IDEAS}

maintained doctrine of the Church that man is different, not only quantitatively, but almost qualitatively, from the rest of the animal world, and that a purpose or ideal is for him more important than any fixed instinct or any vis a tergo-such things seem more intelligible now. Fixed instincts, indeed, "drawn out" inevitably by the appeal of circumstances, would have been fatal to mankind. The history of the planet is strewn with the wrecks of species so equipped. 
Chapter III.

\section{THE VINDICATION OF HERBART}

IF this broad statement of the course of human evolution in its later stages is substantially correct, the folly of the "drawing out" idoctrine, as commonly interpreted or misinterpreted, and of all academic depreciations of "knowledge," becomes obvious. It seems absurd to apply such a metaphor as "drawing out" to an organism pre-eminently modifiable, and pre-eminently hungry for guidance and structure. Michael Angelo, it is true, could see an angel in the roughest block of marble, but a devil could be seen there with equal certainty. Herbart saw a "wild animal" or "personified reason" in the new-born child, though biometrical science can see only one of the alternatives. Formative influences from without have to give outline to the marble and character to the child. The human being "brings with him into the world his future shape" scarcely more than the angel, prophetically seen by the sculptor, was marked out in the marble before the chisel was applied. The fate of the child, so far, at least, as the main interests and motives of his mind are concerned, depends not on heredity, but on environment and education. Thus no system of educational psychology is likely to be a helpful and living system if it does not begin where Herbart begins-with the study of the essential elements in education and environment. Those elements are ideas.

If it be possible-and few men would deny it-so to act on a child as to endow him with pernicious standards of action, "good" being "evil" for him, and "evil" 
"good" ; if it is equally possible so to act on another child that he calls "good" what other men call "good," and in most of the normal actions of his life follows this standard; then the whole philosophy of "drawing out" appears as a false or meaningless philosophy when applied to moral education. For did the corruptor of youth "draw out" from the child what was already latent in him, or was this the task of his nobler colleague? Is moral evil or is moral good innate in man? If moral good is innate, the first of the two educators was a builder-up, not a drawer forth; if moral evil is innate, the second of the educators was a builder-up, not a drawer forth ; if neither is innate, or both are innate in some elusive and indefinite sense, the notion of "drawing out" is again false or infelicitous.

So, at least, it seemed to one writer who, after being puzzled for a time by Herbart's comparative ${ }^{\mathrm{I}}$ neglect of the factor of heredity, and by the hyper-intellectualism-the stress on ideas-that distinguishes his system, saw that the question at issue resolved itself into that of the plasticity or the non-plasticity of the human mind. If the mind were non-plastic, with rigid outlines pre-determined at birth, then, indeed, all talk of a "presentational mechanism" out of which sprang interests and will, would be folly. To attempt to "form a child's character" would be the task of a "vile abortionist." We should be in "error" if we thought that "human life could be built up from without and its form and tendency determined by an artificial arrangement by another of the ideas it was to assimilate." "Drawing out" would be the "teacher's business." True, cases could be suggested-Catholic and other-which seemed to prove the power of an "arrangement of ideas," perhaps of an "artificial" and even false arrangement. And there was the cautious and arresting question of

I The qualification is of importance. He fully recognised factors like temperament, and, on the whole, did more than justice to heredity. 
Herbart: "Does a human being bring with him into the world his future shape, or cloes he not?" Yet it was hard to believe that the vulgar view of education was nearer to the truth than the authoritative and academic view. It was hard to believe that Locke's tabula rasa, though an unsound metaphor, was sounder in some of its elements than Froebel's plant. At last the question was propounded to representatives of the science of sociology: "Is man, relatively to other animals, plastic or non-plastic?" and the answer came that man was not only plastic, but actually the most plastic of all animals.

There should never have been need of the question. Yet the fact was that, apart from Herbartian and neoHerbartian books, from books previous to Rousseau, and from books on religious instruction, scarcely any stress had been laid by educationists on the plasticity of man's mind. The stress was all the other way ; the communicating of knowledge, information, ideas, ideals, was the least part of the teacher's work; the "drawing out" of the child's powers, the cultivation of the child's "faculties," was his all-important concern. In the light of the apperception doctrine, it is now possible to see a meaning in these last dogmas; but without that light they remained as mysteries, which left teachers puzzled and unbelieving, and starved the youth of our land of inspiring knowledge.

And yet worthy motives-though a false psychologylay historically behind the philosophy of "drawing out." Goaded into protest by dry and formal methods of teaching, Rousseau, Pestalozzi, and Froebel summoned mankind to preserve inviolate the "nature" of the child. But of that "nature" they, or at least their followers, ignored the most significant element; the plasticity of the child-his imitativeness and suggestibility-came to be depreciated or denied, and education found itself committed to a doctrine of faculties that needed drawing forth, rather than to a doctrine of capacity that needed direction. The "nature" 
of man was tacitly assumed to be identical with his equipment of faculties or instincts, and thus ultimately to be dependent on his heredity and his past. Herbart was wiser. "What is the "nature' of man?" he asked the facile advocates of the "drawing out" doctrine, and his answer, in substance, was that the "nature" of man revealed itself only in what men have become or may conceivably become-Buddhists or Mahomedans, saints or hooligans, More's Utopians or Swift's Yahoos, the Eloi or the Morlocks of Mr. Wells's Time Machine romance. The plasticity of man contained alike the promise of his glory and the possibility of his infamy. His "nature," indeed, was an unsounded sea.

There was another motive, besides that of protest against formalism in education, which actuated the advocates of the "drawing out" doctrine.

The man, be he priest or sceptic, who imposes ruthlessly on any child a dogma, positive or negative, in which he does not wholly believe-nay, about which he has even a doubt-is not distant in kinship from him who puts a stumbling-block before the little ones. Here is the child, trustful, suggestible, helpless; and here is the man, with all the resources of language and experience and all the mechanism of authority at his command. If, without deliberate, dispassionate, and oft-repeated investigation, he insists to the child on this dogma or that, and, instead of confining himself to the countless matters of the moral and spiritual life about which few serious men in all history have ever disputed, uses his position to warp for ever the plastic soul before him,-such a man would be described, not altogether unjustly, as a "vile abortionist," or, in simpler phrase, as a "cad." In reaction and loathing, educationists have claimed that no one has a right to mould a soul. But they forget that the denial of the right is not the denial of the possibility. The soul has to be moulded, and will be; and the moulding of an earnest 
and intelligent "abortionist" may be better than the moulding of accidental and pernicious circumstances.

Thus Herbart, from the first, was substantially right. The duty of education is that of "building up the child's mind, of constructing in it a definite experience; not acting as if the child had already an experience, but taking care that he gets one." Does the young child resemble a plant, with a form fixed in advance? No. Of all the stages of human development-childhood, youth, early manhood, maturity, age-the stage of childhood is the one least suitably described by the plant metaphor. It is only after the formative action of ideas upon the child has long been at work that the plant metaphor or the "drawing out" doctrine is intelligible or applicable. "In a child's mind a definite interest may be implanted ; the interest of a youth can only be fostered. A child believes what it is told, thinks what it has heard, does what it has seen; we build a world for it......In a youth, on the contrary, we can only widen or narrow the world in which he lives. But one half of his plasticity is still open to influence. In this intermediate state the human being has obviously approached the plant. Already something exists which, if unhindered, developes in a definite way, and which, in an equally definite way, helps or resists any new accession. ${ }^{x}$...... The art of continuing an education, already begun, grows, therefore, more and more similar to the art of gardening."

The present essay is a protest against an entire series of academic ideas that are distracting and deceiving thousands of teachers and depriving their work of much of its value. The statements that commence this essay are false or dangerous statements, if the main task of education is to reveal the glories of nature and to hand on the intellectual treasures of the past. In declarations that the teacher should "never tell a child anything," or that "it doesn't

"Here comes in Mr. Keatinge's doctrine of "contrariance"-and the explanation of it is obvious from Herbart's words. 
matter what he teaches, the chief thing is 'how,' " there is doubtless a thin and fugitive meaning; but there is mischief in them, too. Genuine knowledge education dare not depreciate.

Included in knowledge is moral knowledge. Though legitimate doubts may be raised whether "direct" and "systematic" methods of teaching morals are the only or the best, moral instruction must somehow be given. And by moral instruction is not meant "moral training"training in moral habits. Man's success in the latest stage of the evolutionary process is the result not of habits - which die with each individual, and are not transmitted by heredity - but of ideas and ideals which are transmitted mainly by word of mouth or by the printed page, and give initiative and meaning to habits themselves.

Thus to Mr. Bernard Shaw it may be replied that the task of "forming a child's character" is precisely the task thrown upon modern education by the process of evolution, which has largely stripped the mind of instinct-apparatus, and left it permanently plastic to educational work. To Professor Welton it may be replied that, by means of a skilful but artificial and even fantastic "arrangement of ideas," the "form and tendency of mental life" may be powerfully and perhaps finally determined. To Mr. Skrine it may be replied that the teacher's chief business is the imparting of knowledge (genuine, not verbal) to the child, the introduction of the child to the accumulated experience of the race and to the facts of nature. To Professor Findlay, to Mr. Paton, and to other opponents of moral instruction, replies to the same effect will presently be made.

Herbart had "no conception of education apart from instruction." And, in truth, there is no valid conception of education in a modern state unless education means primarily and mainly the bringing of knowledge and experience to the child. Whatever else it may mean, 
it must mean this. Call the process "drawing out" if you will; but realise that the child is the most plastic of all living creatures, with instincts few or weak or educable, and with no pre-determined form, good or bad. "Drawing out" may then still remain your shibboleth, but the power of ideas will have to be your creed.

Now it was precisely Herbart who emphasised the power of ideas. It was he who showed that "apperception " was the essential process of the mental life, and "apperceptive interest" the central concept of education, linking the instruction of the teacher on the one side with the pupil's will and character on the other. Goodness and badness, looked at in Herbart's way, seemed rooted in ideas, while heredity seemed to retreat into an unattainable background. The argument is plausible, if not convincing. Confidence and conviction will come on opening the pages of Dr. Archdall Reid's Principles of Heredity. An eminent medical man, predisposed (one would expect) in favour of the power of heredity, is here emphatic in urging that the moral life of mankind draws its form and nourishment from ideas. ${ }^{x}$ Subtle factors of heredity and temperament may aid or cross the character-forming process, but Robert Owen was broadly and normally right in urging that, human nature being " the most ductile of all materials," "the character of man is always, without exception, made for him"; at any rate a structure of motives may be superimposed upon the basal instincts. ${ }^{2}$ The paragraphs that immediately follow will keep somewhat close to Dr. Reid's argument.

Parental responsibility and love-is this innate? All evidence goes to show that, as an instinct in the male parent, it is weak in the extreme, and that the father who

I Dr. Reid's famous theory of alcoholism seems quite opposed to the rest of his views, and has been vigorously denied.

= Ultimately education will have to learn how to employ the instincts to the best advantage. 
loves his child loves largely or mainly as a result of the moral demands and expectations of society playing upon the intimate experiences of family life. "Maternity was at a feeble level in the lower reaches of nature ; paternity was non-existent ;" and the same would probably be true of humanity to-day except for the "social traditions" that have gathered around and exalted the family institution. The man knows that love, or at any rate a measure of sympathetic oversight, is expected of him ; the suggestion of it is overwhelming, and becomes a part of himself.

Parental love, or what passes for it and may develop into it, is an element in the spiritual system of social ideals into which he is born. If through some phase of economic pressure the social ideals change and infanticide come to be approved once again, he will sacrifice his child, perhaps without a murmur. Something little short of infanticide prevails at this moment in those "homes" where the child is the chief bread-winner; indeed, the allegation is daily being made that parental responsibility and love are dying out among the poor. Or religious motives, as among the ancient Phœnicians, may call for the sacrifice of offspring, and the sacrifice will be made. If this last example is less pertinent than that of infanticide in proving that parental love is largely an acquirement, it will at least demonstrate to the objector the power of a set of acquired religious ideas over the alleged parental instincts handed down by heredity.

Is there no parental instinct, then? Are the moving tales of novelists all wrong - tales of fathers who, through long years, have never known their children, and yet, at the sight of them, feel some unaccountable affection? Is there no "call of the blood"? There may be. Nevertheless, "heredity" seems at present mainly a theme for novelists and playwrights, a deus (or diabolus) ex machinâ

'Drummond's Ascent of Man. 
of sociological and pedagogical thinking, called in whenever men are too ignorant or too indifferent to push their inquiries far. The notion of heredity tickles the modern imagination in much the same way as the notion of the devil tickled the imaginations of mediaval men. There is something fearsome and fascinating about it. Exactly what amount of potency it possesses can at the present moment hardly be stated with confidence; but inasmuch as influences have, in scores of cases, been credited to it that are demonstrably the results of environment, it behoves us to look with suspicion upon explanations that are very likely to be false. ${ }^{3}$ Entia non sunt multiplicanda praeter necessitatem. Until we are certain that environment, an intelligible and undoubted force, is not responsible in any particular case, we should avoid appealing to an agency whose potency is neither intelligible nor undoubted. ${ }^{2}$

Even maternal instinct has been credited with more than is its due; good mothers are, in considerable measure at least, made, not born. "The mortality of first-born children should indicate that a modern woman carries no instinctive system of baby-management about with her in her brain, even if her savage ancestors had anything of the sort." ${ }_{3}$ That Jewish mothers are more assiduous and successful than Gentile probably springs from the same cause that makes German housewives more successful than English; the cause is difference of training, knowledge, and ideals. Heredity may have counted for much in savage times, as Mr. Wells speculatively suggests; but from the time when man's brain began to grow so plastic that

2 "It may be questioned how far the popular view (of heredity)nay, even the view of many who have been trained in science-is not, in reality, the survival of a very ancient superstition."-Ritchie, Darainism and Politics.

See Appendix I.

3 H. G. Wells-Mankind in the Making. Even here, however, "social heredity" may have been responsible for far more than physical heredity. 
thought and memory could largely take the place of instinct, the power of heredity began to wane. Indeed, in the sense of powerful and definite instincts, heredity became a positive drawback to mankind.

Sexual love, as Dr. Archdall Reid shows, is also probably an acquirement. The animal craving shared by man with the brute is not here intended, but the romantic feeling of admiration and devotion which is the theme of the modern novelist. Such love is a thing of ideas, of ideals, of social atmosphere, of culture-inheritance. Many nations, ancient and modern, have never known of it, marriage in such nations following other lines. In modern Europe romantic love was largely the creation of the troubadours. It was they who threw a halo around love, as powerful as the stigma which, centuries before, was thrown upon it by the monks. What was odious and detestable at one epoch became ideal and fascinating at another. In these days, we are told, still other ideas of marriage are growing up. And it is notorious that in ancient Greece forms of love that are not only condemned by Christians as detestable, but by the State as criminal, were regarded as romantic and ideal. In all such cases the quality and status of a feeling depended, not on heredity, but on social atmosphere and tradition.

Sexual jealousy, too, is a matter of ideas. It had no existence in many systems of society where one man could have several or many wives, or one wife several or many husbands. It arose, and heredity had nothing to do with its origin.

Modesty, too, is obviously an acquirement, resting on ideas. It is non-existent in the untaught child, and nonexistent or fantastic in many races of men.

Love of country is almost wholly an acquired love; the patriot dies for an idea. Possibly some faint tribal instinct may still remain at the base of it; some faint "specific plasticity" may render the child peculiarly susceptible to 
an education in "patriotism." There is no means of disproving this assertion, but there is no clear evidence in its favour. Nations that teach patriotism, directly or indirectly, produce "patriotic" citizens. A government wishful of calling forth national pride in army and navy can do so by means of marchings-past, military bands, naval reviews, empire days, and multitudinous devices of a similar kind, including school lessons on patriotism. The sentiment depends almost wholly on ideas, not on heredity, and its only foe is a system of contrary ideas.

The love of property, like the love of country, may have an hereditary basis. Child-study assigns it a place of importance, one of its forms being called "collecting instinct." Yet, like so many other human tendencies wrongly attributed to heredity, this love of property may quite possibly be entirely a matter of imitation in the child, and of social ideals in the man. Would a child have a "property instinct" or a "collecting instinct" if "all things were common" around him? The answer is at least doubtful. Many tribes, indeed, have had all things common ; and if Socialism were ever to become predominant in modern society, men, presumably, would have to regard the idea of private possession of the means of production as abhorrent. Again, the love of property, whether instinctive or not, is readily overcome at the call of religion, and the devotee will surrender all that he has when he thinks that he is summoned to the sacrifice.

Of religion itself much might be said. It is obviously an acquirement, otherwise the churches would not struggle as they do for the power of educating the young. Whether in the unsophisticated mind, untouched by any process of religious teaching, there is any instinctive turning towards a higher power, can scarcely be determined with certainty. But religion, in its full, modern sense, is certainly a result of education and environment. 


\section{Chapter IV.}

\section{SOME SPECIAL PROBLEMS}

"But," it is said, "there are considerable natural differences between man and woman, and here, surely, we have clear proof of the power of heredity. Woman is more tender, modest, and pure than man; but less veracious, independent, and courageous. Education cannot unsex, changing a man's nature to a woman's, or the converse-this, at least, is beyond its power. Sex is not 'plastic.'”

The question of sex is peculiar. For a woman to be more tender or less veracious than her own father is no tribute to the force of "heredity" in the usual sense. That sexual differences are greater and deeper than any of the other alleged inborn differences is probably true, but they scarcely come into our present discussion. Sex remains a fact, and there is no quarrel in the present essay but with fictions. Perhaps the formula of "drawing out" begins to rise to the level of intelligibility when applied to sex, and Mendelian discoveries begin to have some bearing. We hear much, nevertheless, about the "unsexing of woman," and the power of democratic ideas seems, in certain occurrences outside St. Stephen's, to be asserting itself even here over the most deeply-rooted "heredity." Woman has caught the infection of man's ideas. Even here the power of ideals, of national standards, of cultureinheritance, is enormous. Much that we attribute to differences of sex is actually due to differences of education and environment.

Of the superior natural "tenderness" of woman there is little proof. In the Coliseum, the hunting-field, and the 
milliner's establishment she has shown herself capable of cruelty, wherever cruelty to man, or beast, or bird happened to be conventional. Kindness, like other virtues, seems to depend on ideas or imagination. More modest and pure than man woman certainly is, but here the difference seems largely explicable by social suggestions or demands. In the abstract, equal sexual purity should be expected of man and of woman; yet, as Sidgwick points out ${ }^{\mathbf{x}}$ sexual laxity in man is less destructive of family life, and therefore of society, than similar laxity in woman; thus a moral difference of view would come to be recognised, and tradition would impress this on each generation. An explanation by heredity is far-fetched or absurd. If woman is less "veracious" than man in small matters, more prone to "fibs" and finesse, the explanation may very probably be that the ethical tradition handed down from mother to daughter, or from the girls' school of one generation to the girls' school of the next, differs from the tradition handed down in the case of boys. The explanation is at least as likely as the one by means of "heredity"-that the savage woman's only weapon against savage man was equivocation. We are told, too, that girls brought up in boys' schools adopt the boys' standard of truthfulness. That woman is less "courageous" than man is unproven. She has been trained to timidity in certain directions; in other directions she apparently surpasses man in courage. ${ }^{2}$ Such differences are clearly due mainly to differences of particular ideals. Each sex receives, from an early age, its own social tradition of conduct.

Methods of Ethics.

$=$ One remembers Medea's great protest :-

"Forsooth, 'tis they that face the call

Of war, while we sit sheltered, hid from all

Peril!-False mocking! Sooner would I stand

Three times to face their battles, shield in hand,

Than bear one child."

Again, in the "votes for women" crusade, women are showing immense courage. 
That she is less "independent" and more "conservative" than man, more attracted by authority, ecclesiastical or political, seems, at first sight, true. And yet, on more careful investigation, the fact takes on another aspect. Women who have been brought up as unbelievers, republicans, and the like, have often manifested a high degree of fidelity, if not a fierce enthusiasm, in defence of their revolutionary causes. Perhaps (and very doubtfully) we may say that there is less readjustment among the average woman's ideas than among those of men; first impressions are more powerful with her. This, to some extent, is true even of women who are "converted" to some form of sacerdotal or revivalist religion, such as Romanism or Christian Science; probably there is still the predominance of certain early acquired ideas, verging on the authoritative or mystic, and it is the developed power of these that carries the "convert" into the new fold. That she is more impressionable is doubtless true; that she is more religious than man does not harmonise with the extreme fewness of her contributions to theological and biblical study. The main point is clear: so long as a woman is born into a somewhat different tradition from man-a tradition handed down through girls' schools and through mothers-it is quite doubtful whether the differences between man and woman are as great as commonly supposed.

There is a kindred question. It is sometimes claimed that an hereditary element plays an important part in a man's politics. "We are born Conservatives and born Liberals!" But the course of modern politics is not easily understood on this hypothesis; the political world, like other worlds, seems dominated, not by the forces of heredity, but by the forces linked to ideas. It has already been pointed out that the nation which expelled the Huguenots expelled the Royalists a century later, the ideas of the American revolutionists blending with the ideas of the 
French rationalists to produce the most significant upheaval in history. At the present moment we see new political parties emerging in England and old ones changing their form-a process that can be brought under no other category than that of the struggle of ideas. The heredity of a nation does not change in ten years.

Why insist on the point? Because, if the government of this country is a matter of any significance, knowledge, information, facts bearing on government, are also necessarily of significance; and the school, by means direct or indirect, may rightly be called upon to diffuse true ideas of civic duty. The Herbartian doctrine-that by means of ideas every sane child can be educated into a moral and capable citizen-is the only possible educational doctrine conformable with the existence of a democracy. The alternative doctrine - that character and capacity depend on "stock" and heredity-conforms only with the existence of an autocratic or an oligarchic state ruled by supermen. It is important, therefore, to know whether the one view or the other is correct.

While admitting that hereditary elements may, in a few cases, mould the political views of this man or that, it may well be urged that the same enthusiasm which leads one man to advocate a free library would have led him, if a different series of ideas had been persistently impressed upon his mind, to advocate a rifle corps. The man's politics would then have been different. The apperception masses of the one man respond to one ideal, the apperception masses of the other man to another. The chasm of misunderstanding which separates one party (like one religion) from another is thus mainly a chasm between one towering pyramid of ideas and another. Consequently, an educational doctrine that insists on the ineffectiveness and unimportance of ideas is a doctrine singularly inappropriate to modern conditions.

Do churches and religion accept such a doctrine? They 
do not, and they are psychologically right. They know that, by an early and persistent organisation of a child's ideas, they can mould the child's mind and character. Do political parties accept such a doctrine? They do not, and they, too, are right. The school being largely beyond their power, they employ and manipulate the Press, the influence of which is intelligible only on the hypothesis of the power of ideas. A Press that, since the days of the historical ears of Jenkins, can lash nations and parties into fear or fury,-an educational philosophy is needed which, instead of dwelling in academic remoteness from life, is able to explain the influence of such a Press as this. To say that moral ideas or civic knowledge are essentially and fundamentally impotent, apart from certain subtler and deeper functions of the soul, may be true when uttered with a hundred qualifications and reservations in the philosopher's study, but it is educationally false and pernicious. So long as immoral ideas, civic ignorance, and, indeed, ignorance and error in all their forms, are dangerous to the well-being of the State, the counterparts of these are correspondingly important. Thus, when educational writers urge that the teacher's task is that of "drawing out" something from the child's mind, the reader should seek to know the bearing of this doctrine upon the living problems of the day. Othello's fall was the result of an idea insinuated with infinite skill and pains by one who knew the power of ideas. Britain, too, may fall by her "tonguesters," I while educational science may stand by, protesting nervously that ideas are relatively impotent, and that schemes of civic instruction are psychologically bad.

But one forgets ; there is a remedy. Boys and girls must be "trained to think"; they will then be no longer the obsequious puppets of the Press or the platform orator.

$x$ "Step by step we rose to greatness; through the tonguesters we may fall."-Locksley Hall Sixty Years After. 
Nevertheless, when, in a City omnibus, clerk or artisan or school teacher is observed consuming his morning meal of "office-boy journalism," there seems some flaw in the suggested remedy. Has he not been "trained to think"? Has he not worked assiduously at parsing and analysis, arithmetic and algebra, perhaps even at Latin and Greek-instruments that "sharpen the wits " and "develop the power of thought"? Why, then, this confidence in journals whose smallest vice is silliness? Surely because, as the Herbartian tells us, power over parsing and analysis confers on no man the power to judge of political matters. Such power comes from acquaintance with these matters, from ideas, information, knowledge. The man who is ignorant of football cannot judge of it, however vigorous his "mental training" ; and the man who is ignorant of constitutional history cannot judge of modern politics. It is easy to persuade him that this party or that has brought glory to the British flag; that this party or that has favoured or enfranchised the working man. With one half of the skill and energy employed by journalists in appealing to the prejudices-the "apperception masses "-of their readers, the modern youth could be educated to civic responsibility. This question of "formal training" as a means of "teaching to think" will come up again in the present work, and may here be left.

That national characteristics are the results more of hereditary than of environmental forces has been far too readily assumed. Apart from the "biometricians," in some of whom the confusion between germinal and social heredity seems inveterate, the verdict of sociology is increasingly in favour of environment. Have the brutality and the intemperance ${ }^{x}$ of the eighteenth century largely

'See Spencer's Principles of Ethics. "My good young friend, I want to talk to you about your wine. You don't drink enough. Now take my advice-make your head while you are young." This was the standpoint of a century ago. Nowadays everyone claims to 
passed away from English life? Has the civilisation of Japan largely changed in a generation? Have the Maoris become "orderly and intellectual" in the same brief period? Are Bengalis suddenly discovered (like English women) to possess physical courage as soon as revolutionary enthusiasm touches them? Above all, have nations changed their religion within a few years, with momentous effects on character? If so, the Herbartian doctrine-at any rate in a broad and practical sense-is demonstrated as significant for national life. Ideas are potent, and before their proven potencies the shadowy claims of national and individual heredity begin to appear feeble, if not fictitious.

The protagonists of heredity will lastly assert that genius at least cannot be produced by any process of communicating ideas.

But here, again, though dogmatism on a subject so elusive would be the extreme of folly, the power of ideas in the calling forth, if not the building up, of genius is demonstrated by history. Lombroso's theory, which links genius with insanity, cannot here be discussed. But there is the significant fact that an outburst of genius seems often the direct product of a stimulating environment. When new worlds and routes were discovered West and East, when old literatures were unburied and made accessible through printing, the genius of the Elizabethan age burst forth. The fifteenth-century ancestors of Elizabethan men showed little genius, and yet, if the element of heredity is all-important, in the germ-plasm of these ancestors were contained the mysterious determinants of their descendants' ability. The genius of the age of Pericles was likewise occluded in the loins of the early and undistinguished Greeks. Nay, all the genius of the world was once latent in lowly ancestry.

be "almost" a teetotaler. In the eighteenth century fashionable ladies visited Bedlam in order to amuse themselves with the lunatics. 
One notices, too, that in genius, or at any rate in the great achievements of genius, there is often a duplication. The same discovery, the same invention, is made contemporaneously by two men. No theory of heredity can explain this. And no theory of heredity can explain a myriad of facts easily explicable in the light of the present doctrine; for example, why the Roman Empire produced no biologists.

Though heredity and variation play some part in the production of high talent and genius, rendering the brain and mind specifically or generically plastic to stimuli, and (more important than this) providing a large supply of dirigible and convertible "energy," a larger part is played by environment. Gray saw genius running to waste at Stoke Poges; the missing factor was a stimulating education that might have revealed to the peasantry the pageant of the universe.

Knowledge to their eyes her ample page,

Rich with the spoils of time, did ne'er unroll.

If the middle classes relatively to the lower have proved more prolific of genius, the explanation from environment is infinitely more probable than that from heredity. The name of Darwin would never have found a place on the roll of fame if Darwin had been a poor man; economic conditions would have excluded every possibility of a life of research. "It is a stupid superstition that 'genius will out' in spite of all discouragement. The fact that great men have risen against crushing disadvantages in the past proves nothing of the sort; this roll-call of survivors does no more than give the measure of the enormous waste of human possibility human stupidity has achieved. Men of exceptional gifts have the same broad needs as common men-food, clothing, honour, attention, and the help of their fellows in self-respect ; they may not need them as ends, but they need them by the way." $x$

H. G. Wells, Mankind in the Making. 
Even posts at our most modern universities and in all Governmental departments are practically closed by an unwritten law against men who have had no "public school" education; and even if this law were silently or avowedly abrogated to-morrow, the men devoid of such an education would, through their tricks of habit, or speech, or sentiment, create a hostile atmosphere around themselves, and be almost inevitably consigned in future works on Hereditary Genius to mediocrity or oblivion. ${ }^{x}$

If this is true at the present day, and even in comparatively new departments of achievement, and if, all along the line, poverty and its sequelæ are the gravest hindrances to the development and recognition of ability, the stress laid by Mr. Galton and Professor Pearson on its hereditary nature loses plausibility. "The upper middle class," we are told by the latter, "is the backbone of a nation; it depends on it for its thinkers, readers, and organisers...... It is not the want of education, it is the want of stock," that is the cause of the mediocrity of the poor. Until better evidence is forthcoming than any hitherto produced, we may well prefer to believe with Dr. Archdall Reid that "the environments in which the infancy and childhood of the middle and lower classes are passed are so different that it is not possible to form a safe opinion by comparing adults, or even lads...... While it is certain that the two classes differ much in their acquirements, it is probable that they differ little, if at all, in their germinal peculiarities. At any rate, if they differ, yet, so greatly do man's acquirements outweigh his inborn traits, and so completely are the two intermingled, that we have no means of ascertaining it." 3

I Mr. Galton's early work, Hereditary Genius, is in some respects a painful book. There are plenty of "geniuses" travelling in workmen's trains every morning.

${ }^{2}$ Grammar of Science.

3 Principles of Heredity. 
"But incapacity, at least, is inherited. Many children are born ' mentally deficient,' or even criminally disposed. However 'stimulating' the environment, such children can never become normal."

Again, there is no need in the present essay to quarrel with facts, but only with fictions. Idiocy and insanity ranging upwards into various degrees of mental deficiency are facts, and need not be disputed. But even here modern research since the time of Séguin is showing that education can vastly narrow the gap that is supposed to separate the normal from the abnormal. The scientific study of education is only at its commencement, and yet we know already that the hereditary "dullness" of many children springs solely from adenoids, illness, or lack of air, food, or sleep. The brain is sound, but it is not given a chance. With facts like these before us, and with innumerable other instances of the attribution to heredity of defects not truly hereditary at all, we must hesitate again and again before depreciating the power of education.

But a doubt may still remain in the reader's mind. Every instance of the apparent power of education may, after all, derive some of its strength from the unseen working of heredity. May there not be an inherited bias, a "specific plasticity," which, unobserved but yet potent, reinforces the educational process? It is difficult to prove that there is none, though the laws of evidence direct us to argue from the known rather than the unknown, from the undoubted influence of environment rather than from the dubious and elusive influence of heredity. We have no right to appeal to the uncertain or the unreliable until the resources of the certain and the reliable have been exhausted. Still, is there no crucial proof of the power of education? Can we anywhere find cases in which some deliberate attempt has been made to do what has been declared to be impossible-namely, to "determine the 
form and tendency" of a mind by means of an "artificial arrangement of ideas"?

To isolate a Chinese child from its parents, and test whether, by an English training, it can become English; to isolate an English child, and test whether, by a Chinese training, it can become Chinese-such crucial cases are surrounded by difficulty. Nevertheless, cases similar to these are not far to seek.

It would be quite possible to insert in the present essay a lengthy discussion of Roman Catholic education, for the purpose of proving, up to the hilt, that an "arrangement of ideas"-an arrangement that many people would probably regard, not only as "artificial," but as actually false-is able to influence every side of human character. Such a discussion is omitted for obvious reasons, and it is referred to here only in order to indicate what is the coping-stone to the present argument. Supposing that Roman Catholic doctrines were true, the educational argument based on them would be powerful enough; but inasmuch as every opponent of moral instruction, every depreciator of the power of ideas, is ipso facto a non-Catholic and a believer that Catholic doctrines are largely or mainly false, the argument adduced seems irresistible. If a system of ideas, alleged to be heavily weighted with error, can be so imposed on the child's mind as to influence for ever the three sides of his character, a system of true ideas, moral and civic, should not prove hopelessly ineffective. The only requisites are skill and persistence. In Japan-and, indeed, in many nations during the course of history - the thing has actually been done. If it is possible to make a "good Catholic," it should be possible to make a "good citizen." We may not know the way, but a way there must be.

The Roman Catholic Church, in fact, can teach much sound educational philosophy to modern educators, with 
their pseudo-scientific concepts and their timidity. She knows that the human mind is plastic. She knows the use of colour, ritual, and symbolism. She would deny many of the allegations commonly made with regard to children, such as their resentment of adult influence and their aversion to moral problems. Above all, she knows that an "arrangement of ideas," made with sufficient skill, presents an almost impassable obstacle to change of character. And when she is faced by the fact that sincere and thoughtful men reject her authority, she finds the explanation in their lack of ideas, in intellectual defects, cheerfully regarding her enemies as the victims of "invincible ignorance."

"But," the objector may ask, "if the category of ideas is so fundamental as you assert, if ideas are formative and not merely auxiliary, how comes it that on almost every platform we find scientists and scholars uniting with merchants and aldermen to stress the counter-doctrine of 'drawing out'? Who among educationists holds your view?"

The answer is that this view seems maintained in its essence by the author of the most readable and suggestive book on education that has yet come from an English press. 
Chapter V.

\section{ADAMS'S “HERBARTIAN PSYCHOLOGY "}

Though it is a disaster to education that Professor Adams's Herbartian Psychology is not even better known than it is, no attempt will here be made to pluck the soul out of the mystery of the charm of the book, in order to illumine the sombre, if sulphureous, gloom of these pages. But to show that the doctrines here set forth are neither the novelties of one man nor a mere re-statement of crude popular opinion, through love of paradox or controversy, against more academic opinion, something will be indicated, with sundry digressions, of the drift of Professor Adams's book. The lightness of the author's touch has deceived many of his readers. The same issues of life and death emphasised in the present essay are set forth for the observant in the pages of Herbartian Psychology.

"One main object of this book is to induce the cavedwellers (elsewhere described as " arrogant and intolerant empirics ') to move their heads." And this is done in the only way likely to produce any effect-the book is made to deal with living concepts rather than dead; with concepts like "knowledge," which teachers can understand, rather than with concepts like "drawing out," which few or none have ever understood. This, too, is exactly where Herbartianism has the advantage over every other system of educational thought. A system which starts from the "idea" or "presentation" starts from something that has at least a certain intelligibility; while a system which revels in metaphors like "plant," or starts from "soul," or "will," or "faculty," is handicapped with mystery from the first. The foundations of modern geology were laid 
when, instead of speculating about the remote and inaccessible, men began to observe the physical forces at work around them, and applied what they had learnt to the explanation of the past. The foundations of modern pedagogical psychology were laid when Herbart, brushing aside all metaphors that were not inevitable to the subject, set forth the laws of the interaction of ideas; and, with a guiding thread now in his hand, penetrated further than any of his predecessors into the regions of triple mystery. The soul of a man, like the "soul of a people," consists, in a broad sense, of a mass of resident and predominant ideas; and out of that soul are the issues of life.

This "plant" metaphor, "the greatest metaphor of all, the truest and the best, but still a metaphor," which "holds a vast majority of our profession in its relentless grip"why is it rejected? Because it is almost fruitless. "The kindergarten cannot be evolved from the Education of Man. Between the two there is a great gulf fixed, a gulf that Froebel has not bridged.......To call (a boy) a plant does not advance matters much, and manifestly does not account for the use of cubes, spheres, cylinders, and bricks in the very precise way of kindergarten demands." Froebel, in short, has been unable to attain to a lucid and helpful view of education. His practical suggestions are entirely good, but, "as a psychology, Froebelianism is non-existent." No plant metaphor can explain why one child grows up a Catholic and another a Protestant, or why one man feels an interest in the stars and another is dead to them. The significant things of human life and character escape the meshes of the plant metaphor. "What practical teachers want is a psychology that will work," a system which places all the known mental facts in such a way as to render them available in education.

"The soul" of the Burmese people is Buddhism, according to Mr. Fielding Hall's charming book; the "soul of Japan" is Bushido. 
Other metaphors for the mind seem at first sight equally unsatisfactory; for, after all, a plant is a living thing, while Locke's tabula rasa, mirror, or sheet of white paper, is not. Out of dead impressions falling on a dead surface it is hardly possible to explain human will and character. And yet Locke's view seems full of plausibility. "It coincides so completely with that of the ordinary intelligent man in the street that his following in all English-speaking countries is infinitely greater than any other philosophical writer can command." Now, a plausible and popular view is not to be heedlessly rejected in educational matters; is there no way of lifting Locke's doctrine to a place where it will appear at least as respectable as " plant" metaphors and "drawing out" doctrines?

Our author's passing glance at Guyau's hint in Education and Heredity is here significant. If ideas and impressions are indeed "dead" things, there is a difficulty in explaining will and character by means of them. But hypnotism is a proof that they are not wholly "dead." To say that an idea impressed on the mind of a hypnotised person becomes a living force leading to action, is to assert what the psychologist may carp at and qualify, but what is, nevertheless, substantially true. Force may not actually reside in the "idea," and no Herbartian is so psychologically impossible as to imagine that it does ; nevertheless, force seems to be liberated by it. Synthesise Locke with Guyau, and we have Herbart. "Hypnotic suggestion may act without the formality of the trance, and what Guyau wants us to do is to apply this principle in dealing with our pupils. If he is to be believed,

They'll take suggestion as a cat laps milk;

They'll tell the clock to any business that

We say befits the hour.

"In all probability every teacher to-day does make use of hypnotism. What is the meaning of that power that every good teacher exerts over his pupils? There is 
certainly more in everyday work at school than is dreamt of in the philosophical introductions to our school management books," for philosophical introductions are generally introductions of the "drawing out " do ctrine.

Professor Adams's reference to Guyau may well be amplified by further quotations pertinent to the preceding discussion on heredity and environment. If the "plant" analogy and the "drawing out" doctrine are the last words of educational science; if heredity is omnipotent and ideas are powerless; then, indeed, Guyau is a blind leader of the blind. Though, even then, to be blind with Herbart and Guyau and Adams is more comforting, and even more efficacious, than to gaze into blackness of darkness with Karl Pearson.

"Must it be maintained," says Guyau, "that education is useless, or even powerless, because human evolution is necessary, and that evolution always depends on heredity; ......that a criminal, as well as a poet, nascitur non fit; that the child's whole moral destiny is contained in it while yet unborn, and in later life developes itself relentlessly? Modern discoveries in suggestion seem to be of capital importance in education, because they give us the power of ascertaining de facto the possibility of always creating in a mind, at every stage of its evolution, an artificial instinct capable of producing an equilibrium of long or short persistence in pre-existing tendencies. If this introduction of new sentiments is possible by entirely physiological means, it should be equally possible by moral and psychological means. Suggestion, which creates artificial instincts capable of keeping in equilibrium the hereditary instincts, or even of stifling them, constitutes a new power comparable to heredity itself." Similar thoughts are called forth by the alleged conquests of Christian Science over pain and disease.

To speak of "creating artificial instincts" would be scouted as educational heterodoxy in England. Every- 
thing must be "drawn out" of the child, presumably even the activity of his ear-muscles and toe-muscles and mammary glands. Education cannot "create" or "stifle"-above all, it must not "give." One turns from this weary and dreary educational philosophy to that of Herbart and Guyau: learning from the former that " education must regard its office in very essence as consisting of giving and withdrawing......by no means of merely supervising and tending, like our gardening art, that makes only plants its care"; from the latter that every suggestion is, in fact, a nascent instinct. "As the idea constitutes the life of the intellect, it also constitutes the life of the will."

With a feeling, then, that a system of education which recognises the power of ideas is likely to be of more practical help than systems that deny or discount this power, we turn to Chapter III., noting, as we do so, the confession of the writer: "I am a Herbartian only to the extent that I cannot help it.......It seems to me the best system for application to education.......It fits most readily into my own experience, and seems to me best suited to explain educational facts to others."

Chapter III. is named "The Herbartian Psychology." Now, Herbartians are sometimes regarded as dead to all the facts of modern child study, and Herbart himself is supposed to have "deduced" his educational ideas from a false psychological system. It could be very easily shown that this view is mistaken, that his psychological system was a late, timid, and tentative thing, and that a man may be an Herbartian in educational matters without accepting any of Herbart's psychology except one or two very broad and quite indisputable doctrines. But there is no need to be apologetic, for, though Herbart's psychology may not be technically true in any detail, it is educationally significant in every detail.

$\checkmark$ Herbart starts fearlessly with ideas: "We have failed 
to explain ideas by the mind. How about explaining the mind by ideas?" The critic rejoins that this is impossible ; there must be a "soul" from the first. But a soul without ideas is a soul unknown to us. "A naked possibility," as Leibnitz said, "is nothing." Discussion of it is as frivolous as the speculation of Alice in Wonderland concerning the appearance of a candle flame after it is blown out. "The simple nature of the soul is totally unknown, and for ever remains so"; it is educationally useless to argue about a myth; and a soul without ideas is as great a myth as a faculty without ideas. Herbartianism is one long, solemn, systematic protest against the pursuit of educational myths; against attempting to "draw out " from the soul what is not in it; against cultivating a "faculty" of observation, a "faculty" of memory, a "faculty" of reasoning, a "faculty" of abstraction, a "faculty" of will, a "faculty" of imagination, apart from the presentations which alone give any significance to these faculties. Soul, as soul, is a myth ; faculties, as faculties, are myths; the presentation or idea alone stands out as less mythical, more concrete, nearer to life and meaning than these. And to Herbart a metaphor was every whit as dangerous as a myth.

"Ideas have a vitality all their own-indeed, apart from them there is no vitality in the soul at all." "The soul sinks into insignificance when compared with the ideas." The ideas really make up the mind. The soul is regarded as little else than the battle-ground of contending ideas. "Ideas that form substantial groups or apperceptionmasses have a better chance of a frequent place above the threshold of consciousness than isolated ideas. Our whole intellectual life is spent in forming apperceptionmasses and in expanding old ones." "An idea that necessarily enters into our daily life must form the nucleus of a very powerful apperception-mass," from which it follows that the teacher's instruction will be most 
permanent and effective if its roots reach down to the child's familiar experiences ; an education divorced from life may lack permanence, on strictly Herbartian principles. For, indeed, by these principles the "faculty" of memory is in a measure explained; we remember a thing if we can "apperceive" it, embody it in an "apperception-mass." A poor memory for isolated dates may spring, not from weakness of the memory "faculty," but from absence of apperception-masses, and consequent absence of interest.

Herbart's classification of ideas into similar, contrary, and disparate next comes under consideration. When two similar ideas occur together-the sight of a friend's face and the memory of the same face seen yesterday; the taste of tomatoes to-day and the memory of the same taste yesterday-they fuse with each other. When two contrary ideas occur together - the sight of a friend's face and the memory of another's face; the taste of tomatoes and the remembered taste of oranges-they arrest each other. When disparate ideas occur togetherthe sight of a friend's face and the sight of surrounding objects-there will be a tendency for these to complicate-to form a complex or whole, one part of which may subsequently revive the other. The relation of the first and the third processes to "association by similarity" and "association by contiguity" is obvious.

Very formal and technical all this, doubtless. Very capable of improvement by the psychologists of the future ! And yet by means of these terms we can explain the processes that have made our fellow-men what they are. Take yonder slum child who has never seen the Thames, or the Abbey, or St. Paul's ; never a lake, or a woodland, or a hill; never touched literature, or heard an oratorio, or seen a picture ; how is his mind built up? To prate about the child's "soul" or "faculties" helps us not at all. Application of the "plant" metaphor or the "drawing out" 
doctrine is equally futile. Galtonian statistics on "heredity" merely depress. But when we focus our attention on the process of ceaseless fusion of ideas in the child's mind-ideas of tavern brawl and racing event, gutters and garbage-ze know what the slum child must become. His apperception masses will be so few and narrow that he will grow up blind and deaf and unresponsive to the glories of time and space, for these his experience has never touched. Yet his apperception masses, such as they are, will possess a clear-cut intensity. Year after year the same examples and ideas have impressed themselves on him-fusionfusion-nothing but fusion. He is now a hooligan. "It is no good to appeal to him," we are told by one despairing reformer. "Boys are not influenced by moral instruction," we are told by another. Both men are right-and wrong. If, from his earliest school days, a wholesome, rich, and stimulating mass of story and poem and history had been the youth's repast (the study of nature is a harder thing to arrange, and, though precious indeed, is not entirely indispensable), it is doubtful whether his soul would ever have become entirely impenetrable to appeal or to instruction. The apperception harvest that we reap is the result of the ideas we sow. There is doubt whether any hint of praise or blame, however incidental, any scrap of instruction (unless wholly unintelligible), is ever entirely ineffective; later it may help the apperception process, and prevent in some slight measure that absolute impermeability to appeal and stimulus that is the despair of the enthusiast. "Every idea that has once risen above the threshold has some presentative activity" ; and "its presentative activity is increased every time it rises above the threshold."

Think, now, of another child, acquainted from his earliest years with nature and books and men. With him, fusion is not the only or the main process ; indeed, it is often so inadequate that there is a lack of sharply defined elements in the furniture of his mind; with a thousand 
books to read, and a thousand sights to see, few stand out. His mind grows mainly by complication; the ideas that feed him are, in large measure, disparate. He grows up sensitive to everything - a cultured man.

And what of contrary ideas that arrest each other? The slum boy may reject your moral appeal not only because it is unmeaning-because he has no apperception masses to make it intelligible; he may reject it because of the presentative activity of some opposing idea. A man's lack of moral sensitiveness may prove not the weakness but the istrength of ideas-those that he already possesses. It is partly the power of immoral ideas that has deceived some educationists into the fatal belief in the impotence of moral instruction. The moral obliquity of Fagin's pupils sprang not merely from the absence of good ideas, but from the actual presence of bad ; indeed, as already hinted, teachers of vice and crime do not share the academic view that vices and virtues "cannot be taught."

A recent writer ${ }^{\mathrm{I}}$ has enunciated a doctrine of "contrariant ideas" curiously similar to the one just mentioned.

Not that Mr. Keatinge is satisfied with "the Herbartians." "They leave out of consideration all the stubborn elements of inherited instinct," and "fail to convince us that feeling and will are not forms of the mind as ultimate as intellect." To which an adequate reply has already been made : the introduction of ideas is the teacher's most significant task-"feeling" and "will" and "inherited instinct" being, indeed, beyond his direct influence; consequently, the practical value of an educational philosophy is directly proportional to the stress it lays on ideas. To commence with other factors-c'est magnifique, mais ce n'est pas -pratique; and, in point of fact, whatever is luminous and helpful in Mr. Keatinge's own discussion is found in the many passages that speak of the "energy" or "virility"

x Mr. Keatinge, Suggestion in Education. 
of ideas ; of "idea systems"; of ideas "overflowing into action"; and of the necessity that teaching should "furnish the mind with living ideas." Nay, he holds that education, by adding meaning to meaning-by building up an apperception-organ-is bound by no law of "conservation," but is able to act "creatively" in moral and other matters ; a confession of faith essentially and even verbally identical with the "Herbartian."

Mr. Keatinge adduces illustrations of how moral instruction can be given incidentally through books like Cæsar's Gallic War, or poems like Tennyson's Ode on the Death of the Duke of Wellington. Men who have sung the praises of many-sided interest scarcely need to emphasise their sympathy with such methods as these. Nor need fault be found with his criticism of more direct methods, if, indeed, the masters of our secondary schools are so incompetent, and the traditions of the schools so pagan and bad, that the direct mention of serious topics almost inevitably produces the effect which he describes. That effect is "contrariance." The attempt to give moral advice or enlightenment is liable to awaken revulsion and produce the opposite effect to the one intended.

But the question which Mr. Keatinge scarcely attempts to answer is that of the origin of "contrariant ideas." Whence come these mysterious visitants?" The time has passed-Locke's Essay was published in 1690-when psychology could allege ideas that had no history, no origin, no antecedents. "Association by contrast," too, has been abandoned by modern psychology. If the facts are as Mr. Keatinge states, either the secondary teachers with whom he seems to be dealing are so incorrigibly incompetent that a serious word from them is rendered odious by association with their personality; or there exists in secondary schools a tradition that condemns all reference to moral matters as "bad form." In a later portion of this essay the second explanation will be 
supported by evidence, though the terms used by $\mathrm{Mr}$. Keatinge to describe moral instruction would suggest that there is ground for the former one also. Such instruction consists in "assaults upon a boy's moral standards," "attacks upon his code of morals"-exactly what moral instruction should ordinarily not be.

- The three processes of fusion, complication, and contrariance (or arrest), explain the making of the Catholic and the Protestant, the Chinaman and the Englishman, the Conservative and the Liberal. Think of a Catholic education; the constant strengthening, by fusion, of the same impressions derived from the voice of teacher or priest, and from the mystic ceremonial of worship. Think of the precautions against the entry of contrary ideas, and the ensuring that, if they enter, their presentative activity will be negligible in comparison with that of the rival Catholic ideas, the result being an inevitable arrest. Think of how this last process is effected; how the Catholic ideas are made the centre of a rich complex of suggestions, a series of apperception masses that fill almost the entire volume of the soul ; while contrary ideas stand solitary, attenuated, and ineffective. By a similar process the Chinaman becomes what he is, acquires his intense reverence for parents and elders, for literature and law; his peaceableness and industry; his stoical attitude towards cruelty and death.

Mention has been made of the "presentative activity" of ideas, and the phrase is a reminder that Herbart has enriched educational thought with an entire system of helpful terms. "Presentative activity," "presented content," "mediate interest," " immediate interest," "volitional attention," "non-volitional attention," "educative instruction," "character-forming instruction"; the list is not exhausted, and not one term of it is without meaning and value. Herbart has mapped out, though he has far from l completed, an educational science. But the present 
concern is with Professor Adams's book. And as we are now approaching the crisis of that book-the paragraphs in which the utter falseness and folly of the academic views are implicitly shown-the author's words are better than any other.

"Since apperception means the acting upon a new idea by all the ideas at present in the soul, and since the number and arrangement of ideas in no two souls are exactly alike, it follows that no two persons can have precisely the same idea of anything." "As for the cry of 'things, not words,' things are not a whit better than words in ensuring that the same idea shall be called up in two minds," for there is no "faculty" of observation independent of apperception and ideas, any more than there is a "faculty" of memory in similar isolation. Important though this statement is, it sinks into insignificance before those that follow, fatal as they are to pedagogical orthodoxy. "It is true that the child who comes to school brings with him an enormous number of limitations of the teacher's power"; the limitations themselves are due partly or mainly to the power of ideas; "every idea in that little head is a force with which the teacher must reckon. The very inevitableness of the soul's reaction is the teacher's chief aid. Here he finds the fulcrum for his lever. The rest of his work is actual building-up, edification"- the process described by other educationists as impossible. But still worse heterodoxies remain. "The soul is in the teacher's hands, inasmuch as the apperception masses can be made and modified by the teacher." And at last our Herbartian discussion brings us to the region where good and evil wage their eternal conflict ; we are told the meaning of temptation. "If the mind must wait till the right idea comes along, what an enormous importance must be attached to the theory of apperception masses. If the idea that the soul ought to choose is not there to choose, what can the soul do but 
choose amiss ?...... What do we mean when we say that a man is under temptation? Is it not simply the name for the state of a man within whose soul passes a series of ideas, each seeking realisation, yet each regarded from a certain point of view as evil?" "The state of a soul that is ill supplied with good ideas calls for little comment. Such a soul can hardly be said to be tempted. The soul must be continually choosing among the ideas presented to it, and if the supply of good ideas is inadequate, it must of necessity choose the evil."

Of necessity! We read even here of the "soul" and its act of "choice"; but the stress on ideas takes half the mystery away from the process, and we begin to understand. Goodness and badness seem somehow connected with ideas. Probably they can even be "taught." And the mystery begins to vanish altogether when ideas are no longer regarded in isolation, but as forming powerful groups. "If powerful, compact, well-organised masses of moral ideas are present in the mind, the isolated though intrinsically powerful ideas of evil are rapidly dismissed. The momentary presentative activity of the evil idea sends it momentarily over the dynamical threshold up to the very summit, but equilibrium is soon restored by the contrary ideas of good arresting the evil idea, and allowing the idea of good to rise into the dome by immediate recall."

The philosophy expounded in these sentences is significant to the last degree. The technical form may be rejected if a better can be found ; some reformed "faculty doctrine" may conceivably take the place of this doctrine of ideas; nevertheless, in the present state of philosophy there is no better theory of temptation than the one here given. Taken in conjunction with Professor James's chapter on Habit, it must constitute the summary and substance of any future philosophy of moral education. The student who philosophises in terms of ideas and apperception masses_does actually come close up to the facts, while 
he who philosophises in terms of mystic "soul" or miraculous "will" or metaphorical "plant" can never get within hailing distance.

Herbartianism, by breaking down the barrier between will and the circle of thought, and rooting the former in the latter, ${ }^{x}$ can throw light not only on the psychology of temptation, but on the ethics of forgiveness. Does a man whose circle of thought is perfect sin? There is no such man. But if there were such a man, could he sin? We can scarcely believe it. Sin, in many cases, is demonstrably connected with mental deficiency, ignorance, prejudice, delusion, self-deception, miscalculation, limitation, lack of ideas, lack of imagination, lack of interests. If anywhere in the world a being could be perfectly enlightened and yet commit a sin, he would deserve no forgiveness; he would be devil, not man. It is because more or less unconsciously we recognise the connection of moral evil with mental defect that we think forgiveness is right and rational. Tout comprendre c'est tout pardonner.

"The Christian doctrine of the uselessness of [retributive ${ }^{2}$ ] punishment and the wickedness of revenge has not, in spite of its simple common sense, found a single convert among the nations." Why should it, if man's bad deeds like his good, spring from mere zill, if there is no element of ignorance in his bad deeds, or of enlightenment in his good? We are bound to stress the present doctrine if we are to see any justification in forgiveness. And does anyone allege that the doctrine is necessarily unchristian? Then let him explain two solemn utterances in the New Testament. Jerusalem had slain her prophets, and stoned or crucified those that were sent unto her. Was it through malice or through ignorance? Let the last of her prophets say. "If thou hadst known, even thou, at least in this

" "The will is rooted in the circle of thought."-Herbart.

$=$ The word in brackets is ours. The quotation is from Mr. Bernard Shaw, The Revolution ist's Handbook. 
thy day, the things which belong unto thy peace." "Father, forgive them, for they know not what they do."

Prophets have been stoned elsewhere than in Jerusalem. In the North of England a furious mob once smashed the windows of a public man who had differed from his fellowcitizens on a question of public policy. The fury passed, but he took no retributive action against those who had injured him. He forgave. He knew that the crowd had blundered rather than sinned; that, fed on pernicious ideas, they were unable to conceive of his conscientiousness and rectitude. A series of moral facts was beyond the reach of their apperception masses. Call their defect bigotry, ignorance, lack of imagination, lack of ideas-the action of the crazy mob and the forgiveness that followed only acquire meaning or justification in the light of Herbart's doctrine-the doctrine, indeed, of all wise men-that the human will is rooted in ideas. If we have not solved all moral mysteries by this assertion, we have at least done something towards their solution.

"But a boy or man may know an act to be wrong, and yet do it. 'I see and approve the better; I follow the worse." In common speech this is true. In the same sense, a slum denizen may be said to "know" the meaning of "wheat-field" or "valley." There may be verbal knowledge of moral laws, as there may be verbal knowledge of nature. We may "know" that we "ought" or "ought not" to do a certain deed, and yet the "knowledge" may only slightly modify our conduct. This is true, but shallow in the extreme.

It is well with opponents of moral instruction if they do but protest against the conferring of purely verbal knowledge-against a facile utterance of moral formulæ. Such too often has been the moral instruction employed in the past. But if they are arguing from the feebleness of verbal knowledge to the feebleness of genuine knowledge -knowledge of the "apperceptive" kind; if they are 
inferring that, because verbal knowledge is feeble, the teacher must stand aside and make no attempt to confer genuine knowledge of moral matters, they are engaged in a sorry task. Apperception is the key-word here, as almost everywhere in the educational realm. If we can make our pupils convincingly "apperceive" the real glory and goodness of one act, the real baseness and badness of another act, there is much doubt whether, "seeing and approving the better," they would yet "follow the worse." Plato doubted it; Spinoza doubted it; reflective men have always doubted it. "We needs must," they have said, "love the highest when we see it." Nay, the Bible itself bears testimony to the distinction between verbal knowledge and apperceptive knowledge: "Hear ye, indeed, but understand not ; and see ye, indeed, but perceive not." And as, in these days, the educationist who has once grasped the significance of the apperception doctrine sees it exemplified everywhere, even to tedium, in human relationships, so it would seem that all the compilers concerned in the first seven books of the New Testament felt vaguely or clearly that an element of moral blindness was somehow the explanation of moral perversity. Not one of the seven books but quotes those words of Isaiah. Beyond the task of preventing bad habits and creating good habits and interests, moral education has but one other: to make men not only "see," but "perceive"-in other words, to "apperceive."

In Chapter IV. is discussed the "theory of initial equality"-an academic and antiquated statement of the Herbartian postulate that we have no right to stress heredity until we have exhausted the possibilities of environment; to set sail on the ocean of the unknown before we have dropped our plummet into the depths of the known. Does not the Herbartian doctrine of soulmaking "imply a fundamental equality of the souls operated on"? "And, after all, is there anything so very 
heinous in the assumption that all men are born intellectually equal?"

If we allow for differences of bodily nutrition, general or local, pre-natal and post-natal; allow for efficiency and defects of the senses; finally allow for the enormous environmental differences that equip one child with rich apperception material, and another with poor-if we make these three allowances, there is much doubt whether the vast majority of mankind, with its highly "mixed" ancestry, would not be found to be "intellectually equal." The study of mentally defective children demonstrates the importance of the first two factors, while the study of the apperception doctrine demonstrates the importance of the third. Even if we admit, with Arnold and Quick, that boys differ in "energy," and, with Helvetius, that they differ in "varying desire for instruction," it may fairly be questioned whether even these qualities are not the results of the three factors here specified. At any rate, the belief that all men would judge alike of any presented facts, if only they could be shown the facts in the same way, has been held, our author shows, by men in all ages, and is at the basis of institutions like trial by jury. The difficulty is that men cannot so be shown the facts, no man having the same apperception resources as another. That there are true hereditary differences between man and man is granted; and yet again and again the alleged cases resolve themselves into cases of nutriment, physique, and environment. Thus, if Professor Adams's chapter on initial equality is inevitably the least convincing in his book, the reason is that he is grappling with a "will-o'-the-wisp"- - heredityand discovering its elusiveness. ${ }^{\mathrm{T}}$

x Towards the end he establishes the important distinction between the comparatively easy task of judging and the harder task of thinking. The distinction is hardly recognised in modern schools, and Adams indicates the true line of advance if we are to "make children think" - " not propositions, but problems ; not judgments to be made, but ends to be attained." Heuristic and occupational methods seem here suggested. 
Towards the end of Chapter V. (the rest of the chapter will be considered later) we learn that the "faculty" of memory cannot be in any true sense "cultivated," and the discerning reader will infer that "memory" is mainly a matter of interest and apperception. We remember one thing; we forget another that immediately preceded or followed it ; no "faculty" doctrine can explain this, but the doctrine of apperceptive interest can.

Chapter VI. deals with "observation," and we learn that observation is much the same as apperception; that, at any rate, it depends, not on the sharpness of a "faculty," but upon the presence of apperception masses in the mind. A man may observe one thing well, the next thing not at all ; and no "faculty" doctrine can explain the contrast. "True observation is the offspring of interest and knowledge. We observe easily what we are interested in, or what we already know something about." "Children can observe only what their apperception masses are prepared to act upon; to all else they are literally blind, deaf, and callous." "If we desire minute observation in a definite direction, we must cultivate special knowledge to correspond. If we wish to encourage general observation, we can only succeed by cultivating wide interests." The men, therefore, who urge in one breath that the faculty of "observation" should, above all other faculties, be cultivated, and in another breath discount knowledge, facts, information, and memory, are either preachers of a meaningless gospel, if by observation they mean observation; or of a pernicious one, if by "observation" they mean multifarious gaping at objects in general. All true observation involves non-observation-temporary limitation of attention, temporary employment of a definite apperception mass; and noexplanation in terms of "faculty" is adequate or helpful. Our only "faculties" are our apperception masses.

In Chapter VII. the "faculty" of "abstraction" is 
discussed. The child can only form "concepts" (abstract ideas) if he has gone through rich and varied experience; thus logical definitions and other forms of scientific exactness are not to be expected of children whose apperception masses are few and poor. "Dried specimens, lists of specific gravities, or genders, or constitutional changes"these are some of the devices by which children devoid of rich and living experience of nature and language and books are "taught" science and grammar and history. In reality, "the longest way round is the shortest way home." "Each child must work for his own generalisations." Rich and copious experience and knowledge, apperception material in abundance-this must precede all attempts at abstraction and definition, whether in moral or in other concerns.

In Chapter VIII. another "faculty" is resolved into its elements. This chapter is not, as might at first sight be thought, a half-serious sketch, to be enjoyed, and then dismissed and forgotten. It is one of the most significant in the book. The writer first realised its significance after organising in a difficult agricultural district " a Dickens entertainment." He learnt that most of even the obvious humour of Dickens was unintelligible to many youths and men in consequence of the narrowness of their education and environment-in other words, in consequence of a lack of apperception material derived from books and stimulating intercourse. They could not "see" the jokes, for the "faculty" of "humour," like every other "faculty," is " rooted in the circle of thought." "Jokes only tell where they meet with suitable apperception masses." "The power to understand a joke comes to be the criterion of educational progress." Whosoever can estimate the amount of refined happiness lost to the world through the inability of the ignorant to appreciate any humour beyond the crudest; whosoever can then estimate the similar loss that arises through inability to appreciate poetry; whosoever can 
then sum up these two, will grasp the educational significance of Chapter VIII., and with it once again the enormous significance of the apperception doctrine.

Chapter IX. serves to illustrate the triple process of scientific research ; collecting the facts, collating them, and forming an "explanatory hypothesis." The "faculty" of imagination is here resolved into its elements, and this, like every other "faculty," is found to be rooted in the " circle of thought."

Chapter X. deals with interest and attention, and with the importance of "involuntary attention," identical with "immediate interest." Interest is the formula that links will with knozvledge, bridging over the gap between the sacred and the secular. "The chief characteristics of a man," said Quick years ago, "are his interests, and he is strong in proportion to the strength of his interests, and wise according to their direction." Now, since the teacher who builds apperception masses into the child's soul, and thus renders possible the existence of manifold interests, is no mere dabbler in secular things, but a moulder of character, it follows that the mystery of the will is beginning to fade. "If interest inevitably rouses desires, and desires lead to determinations resulting in actions, there can be no room for transcendental will."

Two warnings are introduced into this last chapter. Interest must be genuine-interest in a subject for its ozwn sake, not an interest produced by an artificial and gratuitous sweetening and simplification. Secondly, there may still remain a large amount of necessary drudgery in school work. 
Chapter VI.

\section{ENTER THE DOCTRINE OF FORMAL TRAINING}

READERS may have observed that in the preceding paragraphs a certain chapter of Professor Adams's book has been almost wholly ignored. In that chapter, the fifth, a rival doctrine to that of interest-indeed, the only rival that has a large body of English followers-is discussed and rejected. The mention of drudgery suggests that it is now time to consider this other doctrine, variously and infelicitously described as that of "formal education," "formal culture," "formal training." Very roughly, it may be described as a doctrine which lays stress on habits rather than on ideas, apperception, and interest. We are told that if a boy at school is brought up in habits of observation, he will continue to be an observer; if in habits of neatness, he will continue to be neat; above all, if in habits of industry and thoughtfulness, he will continue to be industrious and thoughtful. Habits are more important than ideals. In short, we have a "faculty doctrine." Man is endowed with "faculties" of observation, reasoning, will, and the like; if, by means of various school subjects, we improve these several faculties, they will remain permanently improved, powerful weapons in the battle of life.

An example will serve. Hard subjects like mathematics are supposed to cultivate the two high faculties of reasoning and will ; they teach the pupil to think, and they teach him to apply himself. "The boy who shows up a set of algebra examples, honestly worked, has had not only to exert his mind : he has had to exert his will-power, too; he has had to set his face, like a flint, against his inborn vis inertice, 
against the temptation from within to fake his sums, and possibly also against the temptation to seek illegitimate help from without. The class probably goes through without a single word being said about honesty or temptation; the better the class and the better the master, the less will be said. But we have what is better than the word; we have the thing itself - truth in the inward parts with the practice of truth : and it is by practice, not by precept, that we become perfect." ' To this typical passage it will be necessary to return. Its refutation is the main business of this essay.

The reader will note the depreciation of moral instruction-" the better the master the less will be said." $\mathrm{He}$ will note the assumption that there is inborn vis inertia, or laziness, in a boy; that algebra is an uninteresting subject. He will note, in fact, that Mr. Paton's standpoint seems opposite to the Herbartian. He thinks that ideas are comparatively ineffective; that habits are allimportant, that drudgery has a greater educational value than interest. ${ }^{2}$

Let us examine the case. Does the boy believe that the algebra is a senseless thing 3 - the belief of many boys regarding the classics? If so, the boy is being morally injured by being compelled to perform this drudgery. He is not even gaining a useful habit. He is doing treadmill work under the spur of fear, or of some equally low motive. He is being demoralised, not moralised.

If, on the other hand, the boy sees some meaning and value in his task, or, failing to see a meaning, has nevertheless some confidence in the men who impose it, he may then indeed benefit from his hard work. He may learn the meaning of duty. But only then. The teacher must

- Mr. J. L. Paton, Educational Times, July, 1907. Italics ours.

2 It is only right to say that this is not always Mr. Paton's assumption. But the assumption underlies much that we hear in these days.

3 "Tommy-rot." 
somehow array the work of the school under the banner of interest, immediate or mediate ; there must be an idea of goodness or worth.

Professor Adams's words are here of great significance. "It has to be admitted that there are some things in life dull and dreary in themselves; that there is such a thing as drudgery. But drudgery can be overcome, not by a long course of drudgery drill at school, but by stirring up an interest in the process, ${ }^{x}$ or at any rate in the result, ${ }^{2}$ of the drudgery itself. So long as a boy's spirit remains, a course of drudgery leads only to a wild desire to get free from it." "This educational homeopathy stands self-condemned. On the other hand, give a boy sufficient interest in anything, and all the attendant drudgery is cheerfully faced."

Mr. Paton implies that the habit of performing a distasteful task is good in itself. No habit is good unless there is a good reason for the habit. Habits must be judged from the standpoint of ideals. Burglars and brigands may possess all the "habits" that advocates of formal training praise so highly. The deep significance of Professor Adams's “ orchard-robbing” paragraph seems to have escaped the attention of Mr. Paton and his friends.

"What could call into play more of a boy's faculties than orchard-robbing? Almost all the virtues are trained in the exercise of this vice. The necessary planning demands prudence, forethought, caution. The choosing of the right moment implies careful observation, judicious estimate of character, and intelligent calculation of probabilities. The actual expedition demands the greatest courage, firmness, self-control. Climbing the tree and seizing the fruit are only possible as the result of the most accurate adjustment of means to end. All the results aimed at in the most liberal intellectual education are 
here secured; no teacher is required, and the boy enjoys it. Why does not apple-stealing rank with Latin and mathematics as a mental gymnastic?"

Yes, why not? There is "exertion of will-power, the setting of the face like a flint against inborn laziness" in orchard-robbing as well as in algebra. "It demands the greatest courage, firmness, self-control." Where, then, comes in the difference of the two cases? In the very matter that Mr. Paton says should be kept out of sight. A boy is not moral ${ }^{\mathrm{x}}$ because he exerts will-power and sets his face like a flint against his inborn laziness; villains do this as frequently as saints. A boy is moral if he has true moral ideas and seeks to realise them in action; a boy is immoral if he has false or immoral ideas and seeks to realise them in action. It is the ideas, not the habits, that distinguish the two cases ; indeed, the habits may be quite identical.

Mr. Paton specifies "punctuality, accuracy, and neatness" as "school virtues which are in reality great life virtues exemplified and enforced in small matters." Punctuality is no virtue at all if it is the punctuality of the debauchee at his brothel, or of the brigand at his assignation. Accuracy is no virtue at all if it is the accuracy of the forger in imitating his victim's autograph, or of the gambler in keeping lists of racing records. Neatness is no virtue at all if it is the professional neatness of the demi-monde searching for prey.

Mr. Paton's mistake is the one that runs through the entire system of educational thought that has gathered around the fallacy of "formal training." "Cultivating

- Herbart was wonderfully far-seeing on this point. The "second moral idea" refers, among other things, to the quality of strenuousness praised by Mr. Paton. But this "moral idea " is only "moral" when combined with the other "moral ideas." Comte, similarly, regarded courage, prudence, and persistence as not true virtues. Or, as Mr. Wells says, "Your energetic person may be moral or immoral " (Mankind in the Making). 
porver" is not necessarily "cultivating virtue." Doubtless, every boy in Mr. Paton's school comes under splendid moral influence. But the secret of Mr. Paton's success lies just where he least imagines it to lie-in the realm of moral ideas. He may use no "syllabus of moral instruction "; there may be excellent reasons why such a syllabus should not be used, or at least paraded, in any school ; but unless, in some way or other, moral ideas are made to shine out clearly-unless, that is, he attends to the factor of moral insight - the habits acquired by his boys are of extremely little positive account beyond themselves. The value of a public school education-be it great or smallis almost entirely a matter of school ideals. The tradition of the school is the effective agent in moulding the character of the boy-habits are educative only so far as they are linked to that tradition, exemplify and emphasise it. If it is an imperfect tradition, the boy will grow up with an imperfect moral code, unless, of course, a second tradition crosses and neutralises the first. Now, a tradition is primarily a mass of ideals, not of habits. It is actually, though not in name, a "syllabus of moral instruction."

In this discussion of the dogma of "formal training" no mention has been made of the scientific evidence against it recently accumulated in America. Of that evidence $\mathrm{Mr}$. Paton says nothing, though it concerns two of the three virtues which he specifies. The immediate question is the power of ideas rather than the comparative moral impotence of habits, to which reference will presently be made. The affirmation is that a "school tradition" is a code of moral ideas transmitted mainly by word of mouth-by "precept" or its equivalent; and that it is powerful with a boy-far more powerful, indeed, than any Christian code, except, perhaps, the Romanist. ${ }^{x}$ The public school boy

"The "code of honour," whether among boys, duellists, or gamblers, is the most powerful in the world, and clearly proves that religious sanctions are not the only ones. 
derives from it many or most of his standards of moral judgment. Now, this being so, there is no basis whatever for the view that a master should never give moral instruction. He must either leave the school tradition alone, confessing that it is beyond improvement, or that he at least is too impotent with boys to improve it; or, abandoning this ignominious attitude of laissez faire, and realising that he does possess influence-that he is at least as influential as a number of common-place schoolboys-he will seek to improve the school tradition. If once he begins to improve it, he may wish to add to it, and for that purpose may find that even "syllabuses of moral instruction" are useful as providing a few hints and reminders. 


\section{Chapter Vil.}

\section{MORAL INSTRUCTION : METHODS AND DIFFICULTIES}

IN now approaching the controversial question of moral instruction, it seems necessary to admit that there are other educational agencies than this by which mankind may be morally elevated. Among those whose value has been most recently urged, mention may be made of a system of continuation schools organised in the light of the researches of Dr. Stanley Hall and others into adolescence. Motor and occupational work may likewise do much in ordinary and in continuation schools to bring education into contact with life. If such matters are almost ignored in the present essay, the reason is not a failure to recognise their importance, but that the only obstacles in their way are ignorance and apathy; while to the improvement of moral instruction there exist the far mightier obstacles of error, misunderstanding, and prejudice.

It may also be admitted that even the limited problem of moral instruction is at least a hundred years from the most tentative solution. At a time when such a thinker as Mr. A. R. Wallace feels justified in saying that, despite the enormous importance of a continuous improvement in the average character of the human race, "our widespread and costly religious and educational agencies have, so far, made not the slightest advance towards it," small is the probability that an essay like the present, polemical rather than constructive, will influence the details of school practice. Whole departments of the

I Fortnightly, February, 1908. 
present subject are educationally unexplored-nay, the thought of their exploration has dawned upon scarcely a single English mind. Let the reader dwell for a moment on the possibility of a noble school ritual that may every morning usher in the day's work; and on the use of biography, narrative, historical reading, or poem, in such a ritual. Let him reflect, when he hears of the teaching of civics, that Shakespeare's little-used play of Coriolanus deals in the richest and most imaginative manner with the relative dangers and advantages of democracy and autocracy. Above all, let him ask how much scholarly and pedagogical thought upon the problem of Bible-teaching has ever filtered down into the school. $\mathrm{He}$ will then realise something of the task that lies before the education of the future. The purpose of the present essay is to show that the task is worth attempting - that the cause of moral instruction is not a "lost cause"; but that, with regard to actual methods, "direct" or "indirect," we are very much in the dark.

That boys will not be morally guided seems contrary to experience. That they will not be guided by soulless pedants; that they will not render respect to rules that appear arbitrary; that they cannot respond to the full gamut of adult motives; that often, out of what seems sheer obstinacy, they will do the opposite of what is prescribed-all this may be true, but it warns us only against formal, dogmatic, unpractical, injudicious teaching. The author of Hugh Rendal tells us that his hero, after receiving a "lot of infernal pi-jaw," seemed "unmoved, defiant." Nevertheless, "the warning had sunk into his mind, as everything said to a boy will, hozvever deaf he may seem; and, if outwardly he appeared to neglect it altogether, inwardly he gave it a good deal of thought." 1

The apparent "deafness" of public schoolboys (the 
phenomenon seems less common in primary schools) has led Mr. Keatinge to the doctrine of "contrariance," already described.

He holds that the attempt of a master to advise or reason with a class upon a moral question, perhaps, even, to hold up an historical model for admiration, or expressly to elucidate the serious aspects of a poem or an episode, is liable to awaken revulsion, and produce the opposite effect to that intended. The language used to describe the master's procedure is here significant. $\mathrm{He}$ is making "assaults upon the boy's moral standards" and "attacks upon his code of morals."

Now, as already stated, "assaults" and "attacks" are exactly what moral instruction should not be; they are the methods of teachers who, too neglectful or too tactless to have educated the moral sense (which is now so corrupt as to need "assault" and "attack"), hector the victims of their own incompetence. Occasions there are when "attacks" are needed; but the subjectmatter of a genuine system of moral instruction would awaken, not "contrariant ideas," but a loving interest - the interest of a boy who reads the story of the Birkenhead, of the girl who hears the tale of Antigone. What a vision of dull pedantry, normal, installed, inveterate, incorrigible, these words "attack" and "assault" call up! Indeed, at the back of Mr. Keatinge's argument there seems to lurk a deep distrust of the competence of the schoolmaster.

In point of fact, there are hundreds of primary teachers who could perform with considerable skill and effect the task here regarded as dangerous or impossible in secondary schools. Is it indeed the case that secondary schools consist of boys who have been allowed to develop a "code of morals " that needs "attack," and of masters whose influence and skill are so small that their attempts at guidance or elucidation will produce the opposite effect to that 
intended? Is Mr. Keatinge's prescription so necessary as he imagines? Must the master stalk his prey with such an infinity of wariness? Must he be so "reticent," so "discreet," so capable of "diverting the boys' attention from the moral undercurrent" of their work, so fastidious to preserve the "covering of reserve"? Surely there is something wrong with any educational system that produces, normally and inevitably, ideas that are "contrariant" to reasonable morality.

Certainly, boys are often secretive when dealt with alone, and seem unheedful and recalcitrant when in company with their fellows. Certainly, too, let it be repeated, normal boys may revolt, inwardly or outwardly, against arbitrary and meaningless commands, or against exhortations that sound canting and unreal. But the very purpose of moral instruction is to show the reasonableness, the beauty, the meaning, of moral and social duty. Mr. Keatinge's fears are explained if moral and social duty has hitherto been identified in secondary schools with arbitrariness and unreality. ${ }^{I}$ But that boys are actually impervious to moral enlightenment and stimulus-whether they show it or not-is exactly what every student of pedagogy denies. Youth " is the golden period of adult influence, provided it is wise enough not to offend." ${ }_{2}$ Boys must needs love the highest-or, at any rate, the high-when they see it. The difficulty is to make them see; but that difficulty is far less than secondary teachers imagine, and in any case it is the justification of moral instruction, not a reason for its neglect.

- Mr. Keatinge adduces certain experiments of Dr. Boris Sidis to show that " normal suggestibility varies as indirect suggestion, and inversely as direct suggestion." But the experiments were concerned with an utterly trivial and meaningless subject-matter. If there is anything rational and beautiful in goodness, and if rationality and beauty exert an appeal on the normal mind, experiments conducted on the relative merits of the letters $\mathrm{B}, \mathrm{D}, \mathrm{K}$, and $\mathrm{F}$ seem to have as much bearing on moral instruction as on the man in the moon.

Dr. Stanley Hall. 
With a certain allowance for adolescent secretiveness and waywardness, it may be safely asserted that Mr. Keatinge's "contrariant ideas" are the results either of incompetence on the part of secondary masters or of a bad school tradition. "The public schools are generally successful in damping down......searchings of heart...... Happy the small boy who does not lose his sense of wonder and curiosity in intellectual matters as well." $I$ To be interested in books is to be a "swotter"; to be interested in serious problems is to be a "prig."

Rejecting the view, then, that there is any necessary moral recalcitrancy on the part of the boy (and still less of the girl), we are justified in asserting the truth of the Herbartian doctrine, that the circle of thought has influence upon conduct, and that apperceptive deficiency of any kind-ignorance, thoughtlessness, prejudice, delusion, or lack of imagination-must result in moral deficiency. If

Evil is wrought from want of thought

As well as want of heart,

the originality of Herbartianism will consist in the richer significance it sees in the phrase "want of thought."

And now to the concrete.

A groodly number of the poorest people in the East End believe that they will win money on horses, and every street contains a newsagency where, for a price, instalments of "expert" information concerning forthcoming races can be obtained. These agencies are not remiss in publishing the record of their own successes, or in waxing indignant at the failures or frauds of their rivals. Now it needs no profound psychologist versed in the mysteries of "character-building," no master of "child-study," but only a man who remembers his own childhood and observes the human life that circulates around him, to prove that a teacher who, in some way, made it clear to the elder boys in an East-End school how the agents spread their nets and

${ }^{\mathrm{I}} \mathrm{Mr}$. Brereton, Journal of Education, February, 1908. 
brought their prey to shore-how, indeed, it was folly to expect wealth from betting-that such a teacher would produce a certain effect. He would not save every boy from temptation, but he would do something to correct the delusion that betting was clever and manly and probably profitable. Some, at least, of the boys, grown to be men, would say to themselves: "My teacher told me years ago that a man was a fool to bet." "Delusion!" Yes, if any of the world's ills spring from "delusion," " they may be removed, in some measure at least, by instruction. Any scheme of pedagogical thought that denies or ignores such a fact as this is too academic for this modern world of sin and trouble; it needs to be brought down from the clouds to the market-place.

There is no need to assert that in every school there should be given a formal lesson on gambling ; still less that a class should expect such a lesson and know its subject in advance. It is possible to share the fear that, if "direct and systematic moral instruction" were to be hastily installed in every school, ${ }^{2}$ it might, in many cases, become perfunctory and irksome. Everyone remembers, from his own youthful experience, that most vivid impressions were often made by something that occurred unexpectedly, or by some hint that seemed to spring spontaneously from the circumstances of the moment. This is the element of truth in the contention of those who advocate "incidental" methods. If, then, there is any genuine possibility of giving a casual and spontaneous appearance to our moral instruction, and at the same time of ensuring its adequacy, this plan should be adopted. Mr. Keatinge makes some useful suggestions in this very connection.

Here, as in many other matters, Ars est celare artem. Any suggestion of perfunctoriness or professionalism is

'Mr. Paton's word, November 1 $4^{\text {th, } 1906 .}$

"Or, rather, in the "secular curriculum." 
undesirable. There is no doubt that the moral influence of clergymen is sometimes less than it would be if, so to speak, they were unprofessional; boys expect certain scruples, certain prohibitions, from them, and often pay less attention in consequence; while the spontaneous advice of a lay schoolmaster may go home at once. The moral influence of a teacher may thus be far greater than that of any other person in the community. The question arises whether this influence would persist if he were transformed at once into a professional exponent of morals.

Now, if a teacher, desirous of inculcating the lesson above mentioned, can somehow arrange that it seem to spring out of an historical episode then being studied (the subject of gambling is by no means unknown to history); or if in the arithmetic lesson the annual profits of various trades are under consideration, and those of the "bookmaker" can thus be referred to ; or if in any way whatever the teacher can link a few helpful hints to an ordinary lesson so that they may appear spontaneous and informal -this should most certainly be done. Some excellent suggestions of this kind have been made in a somewhat similar connection; arithmetical problems on saving, spending, the use of friendly societies, and so forth, are recommended by the Charity Organisation Society for the inculcating of "thrift." The possibilities of "indirect moral instruction" are indeed enormous, and one of the most valuable results of the agitation for "direct" methods will probably be an increased realisation of these possibilities.

But there is controversy even over the useful proposals of the Charity Organisation Society. It is so easy to criticise the old-fashioned school plans for "religious arithmetic" (i.e., for giving absurd problems on Biblical subjects) that some critics would doubtless object even to the giving of problems on economy of time and similar matters. "If a boy lies in bed ten minutes too long every 
morning, how much time will he lose in a year, in seventy years.....?" Unluckily the word "moral," and all discussions of morality, form standing jokes among the educated part of our nation. But if proposals such as the above are rejected summarily, the agitation for special and specific lessons on conduct will necessarily receive an accession of strength. To reject "direct" methods in favour of "indirect," and then to reject "indirect" methods in favour of none, will be a confession that the objectors do not desire moral instruction at all; that they are either moral sceptics, or believers in the dogma of "formal training."

"But our desire is for "unconscious' moral instruction. That is what we mean by the use of the word 'indirect." "

If so, there is ground for controversy. By " indirect moral instruction" is meant in this essay moral instruction as genuine, explicit, and precise as possible, but given in connection with the ordinary subjects of the curriculum. "Atmosphere" is not meant, and "moral training" is not meant. The ineffectiveness of the latter, apart from some form of instruction or suggestion, will presently be shown. The inadequacy of the former is also demonstrable. Valuable though the "unconscious" influence of a good school "atmosphere" may be, there is a place for consciousness in the education of the one creature in the world that seems to possess it pre-eminently; and a French educator has gone so far as to define education, in words that would shock our English orthodoxies, as "the art of causing the conscious to pass into the unconscious." It is highly questionable whether many normal boys will be warned against the dangers of betting by any studies or pursuits which avoid conscious reference to the vice.

We hear much of the "unconscious" influence of good pictures, good music, and the like. Yet, unless the subtle influences of the unconscious are at some time or other brought into the focus of attention, these influences appear singularly feeble. Herbart was no blunderer when he saw 
more significance in the ideas above than in those below the threshold of consciousness. Many a boy confesses to have been helped and guided by a "straight talk"; it is doubtful whether many boys have ever confessed the influence of a picture or the permanent influence of music -apart from some consciously-apprehended association or interpretation. Children misspell a word time upon time, unless analytic attention is devoted to it; they are ignorant of the pictures that have hung on the schoolroom walls; they cannot tell an author's name, though it has been on the title-page of their favourite book. There is a need for the employment of the focus of consciousness. Cosmologically and educationally, indeed, consciousness is nothing to be ashamed of. Its birth was the highest result of the evolutionary process. And, fortunately, it is ever being born anew.

For generations the human race was dead to the beauties of scenery; suddenly-almost yesterday-the revelation came, and now, with no change of heredity, scenery is valued aright. So with a hundred matters, and preeminently those of conduct. If, in the evolution of the race, the conscious recognition, formulation, and discussion of moral ideals had been avoided-in conformity with the latter-day maxim that "the less said the better"-all of us would be brutes at this moment. A child brought up on such a maxim, deprived of any definite contact whatever, through books, instruction, or the like, with the moral ideas systematised by the race, would be the equivalent of a pliocene troglodyte. For there is "a certain blindness" in human beings, as Professor James points out, and this blindness renders the "unconscious influence" of a cultured environment inadequate.

On the other hand, the inefficiency of mere "verbal knowledge" is notorious and has been admitted on a previous page. In times past we have taught "grammar" too directly. Instead of ensuring to our 
pupils a copious acquaintance, through books and through oral narrative, with language in the concrete, so that the latent laws of grammar, when lifted to consciousness, might stand against a background of meaning, we have insisted upon a premature acquaintance with those laws; and the acquaintance has been consequently fictitious. Something of the kind, though less glaring, may have occurred with our teaching of science. It might conceivably take place with the teaching of morals. But, on the whole, there is little probability of this. Every subject except morals, and, to a less extent, art, is alleged to be clarified and systematised by language ; in morals there is supposed to be need for fastidious and elaborate reticence. Consequently, though the time may come when moral verbosity will be positive danger to education, that time, for England, is not yet.

"The old superstition that children have innate faculties of such a finished sort that they flash up and grasp the principle of things by a rapid sort of first 'intellection' ......has been banished everywhere save from moral and religious training, where it still persists in full force. The higher intuitions," continues Dr. Stanley Hall, "first take the form of sentiments without much insight ;" and it is only by means of language, he claims, that they can be made definite. As another American writer expresses it: "Our best thoughts and feelings never get into currency for lack of the bullion of words out of which they must be minted." Mr. Meredith similarly tells us that "a simpleseeming word is the triumph of the spiritual, and where it passes for coin of value the society has reached a high refinement." 2 In short, though the value and importance of unconscious (or rather subconscious) influences is very considerable-for these afford a background of meaning and prevent our moral instruction from moving in a

' Chubb, The Teaching of English.

2 The Egoist, Chapter II. 
vacuum - there is a place for the employment of a moral terminology. "Any teacher who will question her younger scholars about abstract ideas such as 'duty'...... will find ample proof of vagueness or inexactitude...... The correspondence of word and thought is one of the first things to be learnt." I And yet some of our educationists would have us believe that it is one of the last things ; "the less said the better."

Now, what is true of unconscious influence is also true of unconscious inference. We are constantly bidden to let children "draw their own morals" from what they hear or read. Time was, indeed, when such "morals" could be "drawn" with ease from the stilted stories employed for children's edification, each flagrantly built up for warning and guidance around a didactic element. The story once told, the moral was obvious and obtrusive, and the children, in consequence, may have grown restless and inattentive when this last stage was reached. They may ; it is not certain that they did. The late Canon Ainger was convinced "that, as a child, he was not offended or disturbed by the admixture of the moral powder with the currant jelly," and that the moral stories of the Edgeworths remained " as pictures indelibly impressed on the imagination and as lessons which became part of one's stock of moral wisdom." ${ }^{2}$ With the artificial disrepute of the word "moral" it is legitimate to be sceptical as to the alleged uselessness of the oldfashioned books. With inferior stories, however, apperceptive interest may very probably have failed, for, with the conclusion of the story, no element of novelty remained. Thus, the advice " never to point out a moral," despite the pedagogical profundity it suggests, is pertinent only to the employment of stories of the kind just described. Applied more widely, it would be preposterous. It would mean,

- Suggestions for the Consideration of Teachers.

2 "Children's Books" in Lectures and Essays. 
"Never employ the dome, or summit, or focus of consciousness."

When, in years to come, we shall have discovered material-literary, historical, biographical-thoroughly suitabie for the moral instruction of children, any teacher who systematically abstained from dropping hints that would concentrate or deepen-still more that would widen - the moral effect of this material would be a pedant.

The truth is that upon the comparative values of the direct and the indirect methods, of language and of silence, of the focal and the marginal, there are few men in England thoroughly competent to speak. We are all groping feebly, though some of us, let us hope, are groping forwards. Dense, indeed, is the darkness, and nowhere is it denser than when we hear of the child's power of "drawing morals" for himself.

Certainly, if an unsophisticated man were asked the question, "Who, a child or an adult, ought to be treated by direct methods?" his first answer would be, "The child." The doctrine of indirection is valid and helpful if it is identical with that of apperception, and amounts to a demand that moral teaching be not sprung upon a child unprepared for it by general humanistic instruction or by experience. It is absurd if it means that the child, though largely incapable of "reason" or "inference" in other matters, is able to perceive at once the multifarious applications and significances of a story or an event. The opponents of moral instruction charge its supporters with encouraging "prematurity." The charge should be exactly reversed. It is the opponents who assume in the child a highly developed power of inference, "faculties that flash up and grasp the principle of things by a rapid sort of first "intellection" "; it is they who say that he can safely "draw his own morals." Doubtless he can, if no "moral" needs to be drawn at all. But that he can draw the "moral" from a poem like Excelsior will appear more 
than doubtful to any teacher who has made the experiment. If even the educated adult needs some hints for the interpretation of a noble picture, or sonata, or poem ; if David, who was no child in moral matters, was victim to a "certain blindness" when Nathan the prophet told him a story which, on a small scale, was a model to us of to-day; if these and similar things are true, the common allegation that children can "draw morals" intuitively is singularly stupid.

For we are English, and one of our national characteristics is that lack of moral lucidity to which is traceable the inconsistency and unconscious hypocrisy so often and so justly charged against us. A school manager may be eager for the teaching of courtesy, and yet daily inflict on his friends the most undecipherable of handwriting. Women may struggle for a "vote" in the modern State, and yet never wonder at their exclusion from the priesthood of the Church. A teetotal minister may urge from pulpit or platform the duty of self-control in matters of drink, and yet may himself be unable to endure existence for three hours without tobacco. A housewife may be full of the noblest Christian resolves, may even work like a slave to help the poor, and yet without a qualm pay her laundress the beggarly wage of a sweated industry, and resent as impertinent the appeal for more. Mrs. Jellyby is not yet extinct.

Though John Bull may ultimately ruin himself through hatred of theory and system, and through inveterate confidence in his own powers of "muddling through," he is the sincerest and worthiest of men. His conscience moves his will; he acts up to his lights; he detests the intentional hypocrite, and he is none himself. But the very last thing John can do is "draw a moral" where a moral is at all worth drawing. To allege that he can perceive a significance in unfamiliar circumstances, or recognise a principle in a new garb, or see hidden connections, is to admit one's 
ignorance of John. In his presence the imaginative psychologist can never stop wondering (with the Irishman in Bernard Shaw's play) at his "blessed old head with all its ideas in watertight compartments and all the compartments warranted impervious." $\mathrm{x}$

In Herbartian language, John's most distinctive characteristic is the sharp separation between his apperceptionmasses; in less technical language, a lack of mental agility ; in still other language, an inability to get behind words to thoughts and things, or to pass from thoughts and things to their appropriate words. ${ }^{2}$ Of him it is emphatically false that "a rose by any other name would smell as sweet."

Bring a fact within a category that John supposes himself to understand-the category of "justice," or the category of "liberty," for example-and he is to be relied upon. But the fact must obtrusively carry its category, and the label must be in English letters. Without his categories John is morally helpless ; and, with them, hethe most practical of men-is at the mercy of every user of phrases.

Thus the Radical may enjoy John Bull's Other Island without a qualm of conscience at the character of

IJohn Bull's Other Island, Act I.

2 Examples are provided by this very controversy over moral instruction. Opponents of it in its so-called "direct" form-those who oppose it not for administrative reasons, but because they regard it as impossible and absurd-seem to have no searchings of heart at the fact that for over thirty years direct moral instruction is supposed to have been given in every primary school between the morning hours of nine and ten. Nor does the religious world condemn these assailants of direct methods, though they are implicitly assailing the very thing that the Churches not only approve of, but struggle to maintain. On the contrary, they may look forward to be recognised as sane, sage, and practical educationists, worthy of professorships, principalships, etc. Even Irishmen occasionally manifest John Bull's characteristic incapacity. They will vigorously assert that there is only one possible basis or sanction for moral conduct, and then proceed to champion a second-namely, the "patriotic sanction" represented by the Gaelic League. 
Broadbent; the Jingo will feel no resentment at The Devil's Disciple. For a play is a play. Or Empire Day may be celebrated by the singing of "The Harp That Once Through Tara's Halls," and no one will detect any incongruity. For a song is a song.

John's forte lies in quite other directions than that of subtle morality. $\mathrm{He}$ is not to be blamed for this. If he is a babe in lucidity of thought and consequent consistency of conduct, the fault is with his instructors. What attempt has ever been made to increase his lucidity? If he ignores this little duty and that little decency, the reason is that such duties and decencies have never been convincingly pointed out to him, never brought under a formula whose validity he admits.

Now, what is true of John is also true of John's child. Despite the trailing clouds of glory alleged by poets to attend the growing boy, he, too, possesses, in the opinion of our greatest authority on the subject, "no innate faculties of such a finished sort that they flash up and grasp the principle of things by a rapid sort of first 'intellection." "It must be so, if conscience is a matter of apperception, apperception a matter of ideas, and ideas a matter of instruction. To say that a child can "draw a moral" from a crudely didactic story is true-and entirely insignificant. To say that he can "draw a moral" safely and sanely from a story of any other kind has been refuted time after time by the statistics of "child study." And to imagine that he can not only "draw a moral" without guidance, but extend its significance far beyond the original reference-and such an extension constitutes moral instruction-is preposterous. How the instruction can best be given is a separate and difficult question; that it must be given there can be no doubt whatever.

It was shown, a few pages back, that something could be incidentally attempted even in connection with a subject like arithmetic, and that there were certain advantages in 
such an incidental method. But do not let us deceive ourselves. Professionalism and formality may be the dangers of the "direct" method; but neglect is the equally pressing danger of the incidental and indirect. If the laws of health had been taught efficiently, though indirectly, there would never have been a subject called "hygiene" introduced into schools. If the simple laws of conduct had been taught efficiently, though indirectly, there would never have been an agitation in favour of "direct" instruction. Let us note the facts. The timetable, thanks chiefly to past pressure by the Board of Education, is regarded with such superstitious reverence that many teachers hesitate to digress from the specified lesson to deal with questions closely akin to it. Consequently, the excellent advice given to teachers to use history, literature, hygiene, and nature-study for purposes of indirect moral instruction is too often merely academic advice. If it is the last word in moral instruction, it means that little or no change is to be made for years to come. The time-table of a primary school has to be obeyed; a certain amount of work is specified for each term; and the teacher, in most cases, dare not wander far from his subject.

Let us suppose, however, that our teacher is one of unusual courage, and is willing and anxious to give copious indirect moral instruction in connection with other subjects. How much time is given to history in a primary school? One hour a week. How much to literature? So little that the very name is hardly used ; there is " reading," no doubt (one to three hours in an upper class), and there is "recitation" (thirty to sixty minutes-two or three poems a year are to be learnt by heart). How much to hygiene? Probably none in a boys' school. How much to naturestudy-an admirable vehicle for teaching "kindness to animals," "reverence," and other excellent qualities? None at all in most senior schools. Thus our curriculum, 
being based more on the dogma of "formal training" than on faith in "apperceptive interest" and moral insight, is far less adapted to the purpose of "indirect moral instruction" than it should be.

Some writers tell us that "children love directness, and it is a mistake to go beating about the bush. Next to insincere moralising they...... resent being tricked into listening to ethical instruction in the guise of something else." I But this reduces us to an impasse. If we are to reject both direct and indirect methods, we may as well close our schools and bring the educational farce to an end.

There is some probability that the demand for moral instruction may be more or less satisfied by the addition to the curriculum of a course of genuine literature, to be studied mainly for the sake of its content. Teacher and class may thus sit at the feet of great writers, and moral truth may seem to proceed from sources more impressive than the mere teacher. Or a series of books may be chosen with infinite skill, and problems be set or discussions arranged on their basis. For secondary schools some such plan may be far preferable to "instruction" in the narrow sense of the word. But the fact remains that few schools teach "literature" at all, and that the curriculum as a whole is at present deficient in what American educationists call, inelegantly though expressively, the quality of "meatiness."

The disrepute of such expressions as "moral lesson" or "moral instruction," owing to certain associations, presently to be considered, has led Dr. Stanley Hall to a proposal which may ultimately help the solution of the problem. He proposes "a system of carefully-arranged talks, with copious illustrations from history and literature, about such topics as fair play, slang, cronies, dress, teasing, getting mad, prompting in class, white lies, affectation, 
cleanliness, order, honour, taste, self-respect, treatment of animals, reading, vacation pursuits." Such matters, he tells us, "can be brought quite within the range of boyand-girl interests by a sympathetic and tactful teacher, and be made immediately and obviously practical. All this," he adds, "is nothing more or less than conscience-building." 1

There is a suggestion of informality about this proposal of "talks" that may possibly commend it to many who would object to "moral lessons" of a systematic kind. Indeed, the matters to be dealt with are not all of a "moral" nature, though they are intended to be in different ways practical and helpful.

Some may question whether even these "talks" should be universally prescribed. Here and there a teacher is not on good terms with his class, or possesses a temperament that would deprive the "talk" of any value. This happens all too frequently with "Scripture," "history," "literature," and "recitation" even at the present day. In nine cases out of ten the head teacher would appear to be the most suitable person for the task. Cut off, as he too often is, from the routine of teaching, these occasional talks will provide him with the very best opportunities for making his influence felt in each class. In many cases the lesson may nominally be one on literature or history; some short poem or passage, a biography, a reference to a book, a newspaper episode-these may be starting-points; and the "talk" may be over in ten or fifteen minutes.

There is evidence-despite the demurrer of the secondary master-that such talks as those suggested by Dr. Hall often react powerfully upon conduct. "When at my first school, at. I0 $1 / 2-12$, the head master gave very clear occasional lessons in moral and economical subjects. I can remember vividly to the present day the impression

Youth; Its Education, etc. 
those lessons made upon me." I A well-known opponent of moral instruction recently expressed his surprise at discovering, in the course of an historical research, that the only lessons which remained permanently engraved on the mind of his hero were lessons on moral topics. ${ }^{2}$ Whether the effect was not partly a result of the occasional nature of the lessons is a legitimate inquiry; but the fact remains that, given certain conditions, judicious talks on moral topics are intensely interesting to boys even before the age of adolescence, and are probably as effective as they are interesting.

No slight is intended on the fine work of the Moral Instruction League by the admission that some of the criticism lessons delivered under its ægis have given rise, by their too argumentative and analytic character, to the notion that the systematic teaching of "ethics" was being advocated. The objection would not so much apply to a proposal of "talks." What the distant future may bring forth no man can predict; but for some years to come little more seems possible in many schools than an improvement in the teaching of biography, history, and literature, together with the occasional "talks," not entirely on "moral" topics, suggested by Dr. Hall. Certainly there should be little or nothing of a subtle or controversial nature, no encouragement of casuistry, no consideration of remotely possible cases, no advocacy of socialism or laissez faire. Kirkpatrick, it is true, says that "formal statements and discussion of general principles of morality are often valuable as giving youths clearer and better standards of action," 3 but "youths" do not attend our primary schools.

I Testimony of an eminent scientist in Mr. Galton's English Men of Science.

2 See the forthcoming Report of the Inquiry into Moral Instruction and Training, from which several of the above points are taken.

3 Fundamentals of Child Study. 
They attend, however, our secondary schools; and there is significance in the fact that, though "child study" is ambiguous with regard to the value of direct moral instruction before the age of ten or twelve-in other words, before the accumulation by the child of adequate material for moral apperception-it speaks in no ambiguous language with regard to the adolescent years, when the storm-tossed soul, described in the pages of Dr. Hall's great work, craves-perhaps defiantly-for anchorage. Of all beings in the universe, the unspoiled youth of the age of seventeen or eighteen years is the most susceptible to the direct influence of ideals. He is passing through the period when conversions, dedications, and renunciations are not merely possible or occasional, but are normally almost inevitable. If our secondary schools find him or leave him a "barbarian" then-a creature swayed by persistently "contrariant" ideas-great is their failure, and great is their guilt. Even at an earlier period than this, though he may be "deaf," he is taking in everything. He may be dumb-he has "low power of expression"-but he is the most suggestible creature in existence unless recent studies in adolescence count for nothing. The fact is disquieting, therefore, that secondary masters are the bitterest opponents of direct moral instruction. If their schools are so artificially opaque to moral illumination, Mr. Keatinge's remedy would seem to be the only possible one-namely, a deliberate and systematic employment of such "indirect methods" as may disarm or defeat the "contrariance" which has been artificially engendered. So important, indeed, is the employment of such methods even in primary schools-though not for the reason just alleged-that a few further indications of what is possible may appropriately close this portion of our discussion.

Consider the possibilities of the "recitation" lesson. If every year some twenty or thirty suitable poems were 
rendered familiar to the pupils, who would learn some by heart and others less exactly-poems of patriotism, of courtesy, of unselfishness, and the like-proposals for "direct moral instruction" would lose much of their plausibility. Take hygiene. If this subject had ever been successfully taught in all our schools, a considerable number of items in the current "syllabuses of moral instruction" would be superfluous. Even geography, a subject generally regarded as non-humanistic, could be made a vehicle for moral instruction of the best kind if more stress were laid upon the characteristics and achievements of the various nations of the world, upon the heroism and friendship of travellers and explorers, and so forth, and less stress upon the purely physical side of the subject. ${ }^{x}$ Music, again. If the teaching of songs-generally very good teachingwere accompanied by more frequent references to questions of meaning and authorship, so that they would possess significance and not be mere refrains, music would, indeed, become a moral factor in our national life. There is here, in the correlation of music with history, literature, and the rest of the curriculum, a whole realm of indirect moral instruction awaiting the conquest of the teacher. And if some day a musical genius will arise from out the midst of our primary schools and compose a number of school songs equal in merit to Bowen's Forty Years $O n$, he will deserve and obtain an immortality of fame. But in all circumstances it seems necessary to bring into the child's consciousness the fact that songs, like deeds, may be good or bad, and that they have a meaning; otherwise we shall continue to find that all our excellent teaching of music fails to check the taste for the music-hall type of song. "Formal training" and

I In the great public schools which educate our future proconsuls this subject seems especially important. The history of aboriginal races, the inner meaning of Buddhism, and similar topics should be dealt with, perhaps in a course of reading. 
"unconscious influence" are as inadequate in the musical as in the other departments of school work.

And the same remark applies to the "motor training" of which the school of the future will make so much use. No subject could be better adapted for introducing the pupil to the realities of life-moral, social, industrial. But the element of meaning or significance must be present ; motor training must not be "formal training," or it, too, may fail.

One further remark before the philosophy of moral instruction is stated and summarised.

Some educationists appear to mean by moral instruction something different from anything hitherto discussed. They regard it as the process of sermonising a class on the occasion of some moral offence by one of its members. But there is much doubt as to the general value of the plan. If a boy has blundered through some form of ignorance or thoughtlessness, the blame is partly his parents' and masters' ; and the incident may or may not afford a suitable opportunity for the instruction of the class. "Why wasn't I told?" the boy may rightly ask. If the offence is merely one against discipline, it is comparatively useless for purposes of instruction, as school discipline is only an insignificant factor in life as a whole. Nevertheless, some excellent instruction could doubtless be given in this connection; for example, in elementary schools the need for keeping the playground free from rubbish may serve to teach the duty of caring for public property such as parks. But, as already said, the wider significance must in some way be definitely hinted; the habit, apart from its meaning, is of little value.

To allege, however, as some writers do, ${ }^{x}$ that no serious moral instruction should ever be given except "incidentally" or "as occasion serves"-in other words, that it should be left entirely "to chance," and consist of the

- Mr. Barnett, Common Sense in Education. Mr. Barnett speaks cautiously, however. 
"attacks upon a boy's moral standards" rightly reprobated by Mr. Keatinge-is to advocate the most perniciously "direct" method that could possibly be devised, because the instruction would be personal, and therefore often peculiarly offensive. There is a place for such instruction, but to rely wholly upon it would be to avow a very low educational ideal.

The philosophy of moral instruction may now be summed up in a few sentences.

The "will" is not a separate faculty, but is rooted in the circle of thought. There is an element of insight, of judgment, of apperception, in moral conduct. Virtue may not be knowledge, as urged by Plato; it may be possible for the stupid man to be virtuous, despite Herbart's doubt ; ${ }^{\mathrm{r}}$ but ignorance, thoughtlessness, prejudice, delusion, and other forms of intellectual deficiency are at the root of many moral evils, and they can be removed by judicious instruction.

In this connection the words of the late Professor Sidgwick deserve notice.

"The obstacles to right conduct," he said, "lie partly in the state of our intellect, partly in the state of our desires and will. Partly, we know our duty imperfectly; partly, our motives for acting up to what we know are not strong enough to prevail over our inclination to do something else....... Let us suppose that our notion of justice suddenly became so clear that in every conflict that is now going on......every instructed person could at once see what justice required...... Suppose this, and I think we see at once that, though all the injustice in the world would not come to an end-since there is a good deal of the wolf still left in man-yet undoubtedly there would be much less injustice." 2

I "The stupid man cannot be virtuous." Needless to say, the word "stupid" is controversial, and needs elucidation.

2 Practical Ethics. 
Professor Sidgwick's words assume that intellect, desire, and will are separate faculties. The Herbartian is inclined to reduce desire and will to forms of apperception, and thus to bring them nearer to intellect. But, whatever be thought of this reduction, the factor of insight or apperception is morally important-so important that eight distinct proposals have recently been made to increase the apperceptive power of the modern English child.

If there was no need for the teaching of manners, no National Guild of Courtesy would have been launched some years ago in connection with primary schools. If there was no need for teaching the dangers of betting, $\mathrm{Mr}$. Rowntree's book would not have advocated it; if there was no need for teaching the dangers of juvenile smoking, special addresses on the subject would not have been organised in many districts; if there was no need for teaching the dangers of alcoholism, "hygiene and temperance" would not be found in governmental regulations, home and colonial; if there was no need for the teaching of thrift, the Charity Organisation Society would not have recommended it; if there was no need for the teaching of patriotism, of kindness to animals, of civics, proposals of this kind would not severally have emanated from the League of the Empire and from the Society for the Prevention of Cruelty to Animals, or been adopted in Evening School codes.

"But," critics will reply, "proposals have been made by the Moral Instruction League for non-theological moral instruction." The phrase certainly seems somewhat gratuitous. Nevertheless, there is much doubt whether the advocates of the eight proposals above specified were asking for anything else all the time than non-theological instruction. John Bull's characteristic infirmity of being at the mercy of phrases and categories is here exemplified afresh.

No doubt, when a youth is face to face with the hottest 
temptation of his life, religious motives may be the only ones capable of holding him fast to his ideals; but in a million of the minor moralities and decencies of existence such motives would be grotesquely out of place. No modern historian, no sociologist, would venture to say that morality was entirely dependent on religion, or would deny the existence of at least three "sanctions" for the moral life-the prudential, the social, and the religious. "Reason," too, may be a sanction. On this matter there is really no need for controversy at all.

"But," the critics continue persistently, "the purpose of the proposal was to destroy religious instruction." The criticism suffers from the defect of being false. Doubtless, among the advocates of moral instruction were some who wished for the ultimate secularisation of the schools. The significant fact, nevertheless, is that years ago the negative policy - the "substitution" of moral instruction for religious-was definitely abandoned in favour of the purely positive policy-the "introduction" of moral instruction into the secular curriculum.

"It is monstrous," said one of the men prominent at the foundation of the Moral Instruction League in 1898 , "that children are to be left to grow up without moral ideas." And Mr. F. J. Gould, whose visitation of Leicester schools for the purpose of observing the Biblical lessons was almost the starting-point of the new movement, criticised these lessons, not because of their theological implications, but because lesson after lesson was almost entirely devoid of moral instruction. It was because children were being allowed to grow up "without moral ideas" that the attempt was made to construct some new educational machinery in order that, whatever might be the ultimate fate of religious instruction, the school should not neglect its most pressing duty. Again, if proposals of moral instruction are proposals for the exclusion of religion, it is hard to understand Dr. Hall's suggestion of "talks." 
There is little religious instruction in America; the suggestion can therefore be motived by no hostility.

It is scarcely necessary to discuss the objections commonly felt to the use of the words "graded" and "systematic" in connection with proposals for moral instruction. Possible dangers have been admitted ; and, indeed, all proposals must be regarded as ultimately destined to lose their justification in the transformed curriculum of the future. But unless, as seems the case with Mr. Bernard Shaw, we entirely reject the notion of moral or religious instruction, a rough kind of "grading" is urgently called for ; let the reader consider, for example, the present place of the Seventh Commandment in our schools. Again, Dr. Hall's proposals are for a "system" of carefullyarranged talks. The dangers of "grading" and "system" are formalisation and fossilisation; the opposite danger is revealed in the fact that our lack of system has given rise to no less than eight proposals for supplementary moral instruction. The probability is that in the end our instruction will be made thoroughly systematic in reality, while being informal and almost casual in appearance; that, though a definite scheme will lie behind our curriculum, its details will be embodied in the concrete materials of Scripture, history, literature, hygiene, and so forth.

We have now seen how the cause of moral instruction is hampered at every step. Serious objections there are : administrative difficulties; an overcrowded curriculum; the comparative lack of success in the present-day teaching of Scripture, history, and literature ; the possibility of perfunctoriness and fossilisation; in some schools-but certainly not those commonly contemplated in the present discussion-the danger of a premature treatment of moral topics. But these and other solid objections are sometimes scarcely visible through a thick mist of phantom prejudices. The disrepute-soon to be analysed-of the word "moral"; the disrepute, almost equally great, of 
the word "instruction"; academic depreciations of knowledge in general, and of moral knowledge in particular; related to this, the ignoring of the significance of apperception; the popularity of pseudo-scientific concepts like "drawing out"; the supremacy of the "faculty" doctrine and of the dogma of "formal training"; the wholly unnecessary distraction of the odium theologicum-these are some of the obstacles standing in the way of reasonable reform. Another-and an extraordinary one-is the alleged "dullness" of moral questions. This charge demands a momentary investigation.

That moral instruction has sometimes, even with oldfashioned teachers, formed the most interesting of all subjects has already been shown. That the charge of dullness is sometimes due to an identification of instruction with pedantic sermonising is also clear. That moral instruction-like any other instruction-will be dull in the hands of a dull teacher is equally certain. But the common charge of dullness is usually traceable to a misunderstanding so extraordinarily stupid and grotesque as to reflect gravely on the intelligence of educationists.

Certain Government inspectors of a bygone age are said to have found the songs taught at the training colleges which they visited reprehensibly uniform. The visitors were quite "bored" by the lack of variety. Many teachers, too, find excellent ballads like The Wreck of the Hesperus altogether too "hackneyed" for employment in school. Moral topics are naturally said to be "dull" also.

Now the fallacy in all this is obvious to anyone who remembers that apperceptive interest demands both the new and the old, an element of novelty and an element of familiarity. Hundreds of things are "dull" to adults which are intensely fresh and interesting to the young. Any moral topic suitable for school discussion must almost

Example taken from a lecture delivered by Professor Adams. 
necessarily be one from which all novelty has departed for the adult. He accordingly finds it dull, prosy, hackneyed, sententious. And thus, on the basis of his own feelings, which have nothing to do with the matter, he pronounces an educational verdict which, though altogether contrary to actual experience, carries, among the educated part of the English nation, the impress of sound common sense. ${ }^{x}$

It seems necessary, in drawing this argument to a close, to repeat the caution with which it commenced. No one claims that improved moral instruction, either direct or indirect, will be a panacea for all ills. It is only one agency out of many, and in France its effectiveness seems somewhat reduced by the neglect of these other agencies. But to urge the value of school discipline, of wholesome environment, of corporate life, is no answer to the clear demonstration that moral instruction-or moral "suggestion"-is needed. The time may come when the minds now devoted to the cause of moral instruction may urge the importance of other factors. Or a happier time may come when all factors will have been so adjusted to national needs that advocacy of any one of them would be gratuitous. That time is not yet. The immediate need is to stress the importance of moral instruction.

The case for it seems strong enough when we realise that much moral evil springs from ignorance, thoughtlessness, prejudice, delusion, and want of imagination. It seems stronger yet when we look at moral ideas in the Herbartian way-not as mere knowledge acting distantly upon the desires, the motives, and the will, but as the roots of these. "Acts issue from the idea of the act....... Ideas influence life, and can regenerate character; and instruction can influence ideas." 2 And the case becomes

- The point was well and frankly brought out before the Inquiry into Moral Instruction and Training, by one of the witnesses who had previously objected to moral instruction.

Dr. Sophie Bryant. 
overwhelming when we realise that there are bad ideas as well as good, and that the bad ideas may forestall the educator and reduce certain of the best results of child study and university pedagogics to academic and even dangerous fictions.

It is just here that Professor Findlay falls into error. Acquainted better than almost any man with modern educational thought; impressed especially by the truth that reason cannot work well in a vacuum, but needs a basis of rich experience and knowledge-of "apperception-material "-for its activity, he urges that there should be no "premature" introduction of morals. He sees the boy living in a utopia where few moral problems assail him, and where, therefore, their consideration can be postponed till the middle teens. He has forgotten the EastEnd boy, prematurely wise on scores of things, deluded by false ideas on scores of others. Picture this boy, focalise him, realise him; and then read Professor Findlay's warning words :-

"Let virtue grow in its own time; leave these quiet waters to their own channel; let reverence and hope have a chance; leave some part of revelation, of insight, to come after you have ceased to expound.......I distrust the hands that want to stir my child's inner nature. Experience, all about him, is stirring him every day, and he will respond in his own way if you will forget that you are a moralist, and remember that he is a child." I

There, in black and white, are the words. We should, indeed, remember and remember and remember that the " child" is a "child." Is it not Professor Findlay who is picturing him as a reflective man, able to resist suggestion and to analyse experience with infallible judgment? Experience, indeed, is "stirring" the child. He will, indeed, "respond in his own way." 
"I distrust the hands that want to stir my child's inner nature." Advocates of moral instruction have never felt themselves primarily concerned with a child brought up in the cultured home of a University professor. They have little fear for such a child. But Professor Findlay would himself hesitate to take the responsibility for a child brought up without instruction amid the moral delusions of the East End-the district which had something to do with the movement in favour of improved moral instruction.

As we scan, one after another, the active critics of moral instruction-those who oppose it not as administratively difficult or undesirable, but as inherently impossible-we recognise that they are thinking habitually in terms of a cultured environment ; and that one of them, at least, has done his thinking aloud. We know the images that rise before his mind. "There is no dispute among children," he tells us, "as to conscience and the moral standard." Mr. Paton is nearer the mark. He "trembles to inquire" of what kind is the beauty that passes into the soul of the modern urban child. To him, what "passes in " appears of importance.

How to meet the situation-what type of instruction or training is best fitted to counteract a pernicious environment-is a question which the pedagogy of future years can alone decide. But that the situation can be met by letting virtue (or vice) "grow in its own time"-by a policy of mere laisses faire, hailing, once again, from Manchester-is improbable in the extreme. 


\section{Chapter Vili.}

\section{EXIT THE DOCTRINE OF FORMAL TRAINING}

THE opposition of Professor Findlay is thus mainly based upon grounds entirely untenable; he visualises a middleclass child, and protests against prematurity of moral treatment. Mr. Paton's grounds are different; he relies upon the dogma of "formal training." It is now time to turn to the refutation of that dogma, thus picking up the thread that was dropped at an earlier page.

"There is a prevailing impression among teachers," says Professor Adams, "that it really does not matter very much what one learns.......It is not the what, it is the how." Classics and mathematics are supposed to train the mind in a general sense, to make it capable of grappling with the problems of life, even when these have nothing to do with classics and mathematics. And yet, on further investigation, one doubts whether this is so. "Each subject cultivates, not the mind in general, but in certain special directions. In other words, formal education (training) is not quite so formal as it is supposed to be." The man who can best find a lost will, for example, is not necessarily the mathematician, the scientist, or the classicist ; their training does not necessarily equip them with the particular skill needed; an experienced lawyer is, probably, the best man to employ, not because his mind is "best trained," but because he has accumulated information -apperception material-relative to wills. Thus the comparison of the mind to a knife (as when we speak of "sharpening the wits") is not felicitous; we cannot make the mind sharp in a general sense by using any 106 
particular "whetstone of wit," such as grammar or algebra -we can only make it sharp in particular directions.

Power and skill and the other qualities desired by the advocates of formal training depend on apperception masses, and are limited by them. "We can all judge, we can all reason, not so much according to our 'natural powers'....... as according to our familiarity with the subject under discussion.......Think of Laplace, the great Laplace......dismissed by Napoleon for incapacity, and say whether the greatest mind may be truly called great when tested apart from the apperception masses with which it is familiar. Had Laplace's mind been the highly-trained instrument formal educationists would have us believe, he ought to have been as good a minister as mathematician."

Similarly with certain other habits and qualities, including one of those especially mentioned by Mr. Paton. "A boy who is punctual, respectful, and obedient at school, it is said, will not lose those good qualities when he goes to an office. Yet," continues Professor Adams, "even habits bear the traces of their origin.......Is it so very unusual to find a boy obedient at school and unruly at home, respectful in the office and impertinent in the street?" Habits do not seem, to any important extent, to become generalised; the generalising factors in conduct-though our author does not expressly say this--are not habits, but ideas. With this significant conclusion, that formal training qua formal is a myth, and that the element of moral instruction is needed to supplement the training, we close, almost finally, the pages of Professor Adams's book.

Mathematics is commonly alleged to develop will-power through the process described by Mr. Paton as "setting the face like a flint." It is also supposed to develop " accuracy." Likewise " reasoning."

Now, will-power, as already pointed out in connection with orchard-robbing, is not, in itself, a moral thing. 
Villains possess it as well as heroes, and "instruction in crime " may be as efficacious in its production as instruction in science and classics. Thus the development of willpower through mathematics, is no part of moral education at all, unless an idea of rational duty is dominant all the time. No doubt, Mr. Paton intends that it should be dominant. Only he unfortunately implies that "the less said the better" about all such matters.

Accuracy, too, is supposed to be developed by mathematics. And yet there are uneasy doubts whether this is, indeed, the case. "I once heard a prominent teacher of mathematics give, as his excuse for keeping the company waiting for his paper for half-an-hour, that he had misread the time on the programme; then he presented his paper in defence of mathematics as affording superior training in accuracy. The worst of it was, nobody seemed to notice the incongruity." I Accuracy in mathematics is, doubtless, developed by means of mathematics ; but accuracy in general is not. The only way to develop that is to acquire a moral or semi-moral idea ; in other words, to regard "accuracy" as a duty, which it sometimes is, and sometimes is not. But no such idea will be acquired if, on matters of this kind, schools act on the principle that "the less said the better."

Reasoning is supposed to be developed by mathematics. But here, again, there are doubts. In Swift's caustic satire, the mathematicians of Laputa appear as "very bad reasoners," and Laplace, as we have seen, was incapable as a statesman. Reasoning about mathematics is developed by means of mathematics; but reasoning in general is not.

Much the same may be said with regard to the alleged training power of the classics in secondary schools, and of arithmetic or English grammar in primary schools. The

I Horne, Psychological Foundations of Education. 
first of these only need be considered here. "The majority of the boys turned out (from secondary or public schools) are intellectually in so negative a condition that any change would be an improvement....... It is impossible to have anything worse." These are the words of $\mathrm{Mr}$. A. C. Benson. ${ }^{x}$ And another recent writer tells us that the boy whose brilliant classical career he had studied with sympathetic attention possessed at the end of it an "atrophied intelligence." 2

To the Herbartian, not only the "atrophied intelligence" of the one boy, but the "low moral admirations" assigned to another by Mr. Skrine, are intelligible. Public schools have valued training, and have ignored instruction. They have thought that habits would generalise themselves into tendencies and virtues, and that "the less said" about these latter "the better." Boys have been starved of ideas. For ideas, and particularly moral ideas, are inevitably at a discount where the doctrine of "formal training" prevails, and where, therefore, the rival doctrine of apperceptive interest is rejected or unknown.

The dogma of formal training - faith in which constitutes the greatest educational superstition of to-dayneeds to be statistically refuted. But the difficulties are considerable. To prove that the mere "training" of a public school (training apart from instruction) is a failure in every respect would be impossible; for a complete divorce between training and instruction rarely or never exists. So long as there are noble ideas of duty, noble traditions of conduct, connected with any institution, instruction is being given; the institution is not one for mere training. But, curiously enough, two out of three of the school virtues mentioned by Mr. Paton have been the objects of experimental investigation in America, and, though they are not the most important virtues of the moral catalogue,

2 " Kappa," quoted from below. 
there is reason to think that their acquisition is typical of the acquisition of all.

Can "accuracy" be generalised? Does " accuracy" in one department of work lead to accuracy in another? The thing has already begun to appear doubtful. We remember Professor Horne's anecdote of the mathematician who misread the time ; we remember Professor Adams's words : "A man may be an accurate sorcerer, and yet a very inaccurate arithmetician"; we seem to remember cases of conflict in our own experience. The American evidence thus comes to us with scarcely a shock. ${ }^{x}$

Individuals were practised in estimating the areas of rectangles from ro to roo square centimetres in size until a marked improvement in accuracy was attained. Areas of the same size, but of different shapes, were then substituted, and the power of accurately estimating the areas at once fell off 56 per cent. If the rectangular shape was retained, but the size of the figures greatly increased, there was a fall amounting to 70 per cent.

Acquired accuracy, in other words, can only be transferred with very great loss, even when the new class of objects is somewhat akin to the old. If the new class were quite distinct from the old, there is no reason for thinking that even the least transfer of power would take place.

The next case is worse. Persons were trained to accuracy in estimating weights varying from 40 to 100 grammes. They were then tested on weights of a much greater amount- 120 to $\mathrm{I}, 800$ grammes. Accuracy of judgment fell off $6 r$ per cent.

Practice in estimating small lines varying from $\frac{1}{2}$ an inch to $1 \frac{1}{2}$ inches in length gave no improvement rohatever in the power of estimating much longer lines-6 to 12 inches. Again, as most teachers would have admitted if

' See Bagley's Educative Process. 
asked, "accuracy in spelling is independent of accuracy in multiplication."

From these simple but significant experiments we infer that "habits bear the trace of their origin." It is impossible to make a man generally accurate by insistence at school on specific accuracy in translating the classics or in solving problems. Unless these processes are regarded by the boy as explicit exemplifications of a principle, they are morally of small importance. Yet we are told that a class may benefit by a certain course of drill, without a word being said regarding the moral principle involved; indeed, "the better the class, and the better the master, the less will be said." "It is by practice, not by precept, that we become perfect." It is indeed, provided the precept be somehow recognised from the first.

Another of Mr. Paton's "school virtues" is " neatness," which, he tells us, "is in essence a form of respect for work, for duty, and the person to whom the duty is discharged. It is an expression of that virtue which is never acquired if not acquired in childhood-viz., reverence." Excellently stated; but whoever imagines that "the less said the better" about neatness and reverence, that the more completely neatness is reduced to a mechanical routine the more successfully will his pupils acquire true neatness and reverence, is anchoring his faith to an educational fallacy. Neatness depends on ideas and ideals, and, consequently, upon some form of instruction, direct or indirect. Insistence on merely habitual neatness of one kind will not give rise to neatness of all kinds. Many teachers imagine that it will, though every scrap of available evidence is against them.

"At the Montana State Normal College careful experiments were undertaken to determine whether the habit of producing neat papers in arithmetic will function with reference to neat-written work in other studies. The results are almost startling in their failure to show the 
slightest improvement in language and spelling papers." In short, unless ideas are given concerning the duty and importance of neatness-how neatness is, indeed, an exemplification of "reverence" or respect for others, a form of unselfishness or courtesy-all our insistence on mere school neatness is likely to be thrown away. The habit does not generalise itself. Moral instruction or "suggestion" has to be given.

We shall not make our girls into neat housewives by making them neat writers, we shall not make our boys into neat men by making them keep the school playground neat, unless, in each case, the significance, the reasonableness, of the duty are recognised. The summit of consciousness is not the negligible region that many of our educationists suppose.

Unwept, unhonoured, and unsung, the dogma of "formal training" thus vanishes from the scene. Alone, unsupported by the complementary and necessary dogma that ideas as well as habits, instruction as well as training, are essential to moral life and growth, the luckless dogma, brought forth in an evil hour to justify and excuse a ridiculous curriculum, is now known at its true value.

"The theoretical impossibility of a generalised habiteither marginal or sub-conscious-is thoroughly established." "Improvement in any single mental function need not improve the ability in functions commonly called by the same name; it may injure it." The study of grammar does not "train the mind to think"-except about grammar; it does not enable a person to think soundly about politics, or law, or geology-it does not develop a general "faculty of reasoning." Hard and concentrated work with one subject does not develop a "faculty of attention" (or "will") equally applicable to subjects quite remote. Habits remain specific, and can only be generalised and rendered morally significant under the influence of a principle or ideal. There must be a 
recognition of the significance of what we are doing. This is Mr. Keatinge's contention; and he is right.

To this statement two objections may be made. A public school education based on classics and mathematics is said to be notably efficient in the production of character. It works well in practice. This claim comes, however, mainly from the picked public men who have themselves received such an education, or from those who are engaged in giving it. Evidence from such sources is not altogether impartial; while negative evidence from the outside, or from public schoolmen like Mr. A. C. Benson and the anonymous writer "Kappa," is essentially more weighty. That clever men have survived the influence of any school, and have become eminent, is no proof whatever that the school curriculum has made them eminent; the school tradition-a mass of ideas, not a prescribed routine of habits and pursuits-may have been the potent factor, if, indeed, any educational factor has been potent. So far as the training of any school is an explicit application of fine and noble ideas, it serves to engrave these ideas on the minds of its scholars. There, and there only, is the element of truth in the dogma of formal training-exactly where many of its supporters least suspect it to be. He who would make bold to say that moral training is valuable only so far as it is a form of moral instruction would be actually nearer the truth than he who contends that a habit apart from a controlling idea can be generalised.

The other objection comes from the reader of Professor James's Principles of Psychology. "Has not the brilliant American," he asks, "shown the fundamental importance of habit in a chapter that, within fifteen years, has already become classical?" He has. Habit is undoubtedly fundamental; and the fact is an amazing one that this chapter of James's-the best scientific sermon in our languagehas not found a place in every school. But animals and 
plants have habits; and the man who imagines that human education consists only in habit formation, to the neglect of everything else (about which "the less said the better"), is a man who implicitly regards the human race as a race of brutes. Nevertheless, the establishment of good habits and the prevention of bad are among the teacher's chief concerns; and much of the best moral instruction may ultimately be given on a basis of school occupations, in the course of which habit and insight may develop side by side.

A habit of early rising, or a habit of taking a morning bath, may be excellent. But if their excellence is to extend beyond themselves, some general maxim or principle must be recognised as justifying the habit. "I believe in punctuality," "dirtiness is selfish and unhealthy"-something of this kind must be present; there must be the element of moral insight, judgment, or conviction. If civilisation consists largely in a body of such general maxims, judgments, or convictions, which are, indeed, no other than the moral conquests and discoveries of the countless years of man's ascent, are we to denounce, renounce, or even keep in the background, these the greatest achievements of the race, and fall back on a process that assimilates the education of the child to the education of a performing dog? Such an education is the one that lays stress on habits and forgets instruction. Habits-one cannot too often repeat-are specific, not, to any important extent, generic.

But the word "habit" is ambiguous-a fact which accounts for much confusion of thought upon this subject. "It is not those outward and overt performances such as we can most easily compel, that really form the habits we call virtues.......It is the repetition of psychical states that are the causes of the formation of moral habits....... If the psychical states......the strivings of desire, be not induced, the moral habit will not be formed, not even though we 
could compel the whole physical side of the performance" ${ }_{1}$ -a statement which means, again, that unless habits are accompanied by insight they are morally unimportant. Now it is very doubtful whether insight can be conferred without moral instruction of some sort-conferred without words passing from book or teacher to the pupil. If, then, training is necessary to give reality and stability to instruction, instruction (or its equivalent) is equally needed to give generality and significance to training. Broadly and epigrammatically it may be said that, if instruction without training is empty, training without instruction is blind.

' MacCunn, The Making of Character. 


\section{Chapter IX.}

\section{PREJUDICES AND PREDICTIONS}

THE last word has been significantly employed by $\mathrm{Mr}$. Skrine in one of his confessions concerning the publicschool boy. He is said to be "morally colour-blind." Other writers frankly describe him as a "barbarian." Now, it is frequently contended that there is a parallelism between the evolution of the race and the development of the individual. Sociologists like Dr. Archdall Reid tell us that the main difference between the barbarian and the civilised man is a difference, not of bone or blood or heredity, but mainly of social tradition; and that a barbarian child, brought up from the first amid a European environment, may easily leap over a hundred thousand years of progress, and become, possibly in all except temperament and the strength of certain emotions, a European. He will admire what Europeans admire, hate what they hate, believe what they believe. Conversely, a European child, brought up among barbarians, will lose those years of progress and grow up like the men around him.

Now, is it possible that the alleged "barbarism" of the public-school boy-his alleged "colour-blindness" to moral truths-is partly due to the same cause that keeps a genuine barbarian from civilisation? Is it that the ethical traditions and treasures of the race have been withheld from him? Or is it that he is a colour-blind barbarian by nature? Once again the perennial problem of heredity and environment faces us.

It has been admitted, in connection with Mr. Keatinge's doctrine of "contrariance," that many boys will show a 
certain degree of wildness, exuberance, and apparent recalcitrancy during their early teens. Yet there is doubt whether the adolescent crisis is enough to account for the "barbarism" alleged against them as normal and inevitable. It does not exist in Japan $;{ }^{x}$ the idea of boyish ragging, rowdiness, and insubordination seems not to cross the mind of the Japanese schoolmaster; boys come to school to learn; soldiers fight, but boys do not. There is, too, a certain difference between elementary and secondary boys in the same respect, though the age question introduces here an element of uncertainty. It is necessary to protest, therefore, against the too facile assumption that a period of "barbarism" is inevitable in boys. There is a more likely explanation.

If sociologists are right in their view that the fabric of civilisation and morals is maintained by the handing down, from one generation to another, of a social and ethical tradition, and that with the blotting out of this, civilisation would perish in a moment, the question arises whether our great public schools are helping to hand down this tradition. If they fail in this, they would seem to be doing their best to create a race of "barbarians," a barbarian being, by sociological definition, a man who has never received the social and ethical tradition which maintains the fabric of civilisation. Can it be that our public schools-and, to a greater or less extent, our other schools -are afraid to teach conduct?

The reply is that they are. They admit it. They parade it. Mr. Skrine assures us that the public-school boy has "low moral admirations." What deliberate attempt is made to give him "high moral admirations"? The answer comes at once : such an attempt would make a "prig" of him. In other words, public schools are so

- Mr. Brereton's article on French moral instruction is also significant in this connection. 
afraid of the semi-mythical quality known as "priggishness" that they almost entirely leave moral ideas alone, and fall back, to ease their consciences, upon the dogma of "formal training." Doubtless, the boy receives a moral tradition, but he receives it from his companions; and, though not without excellent features, it is so deficient in many of the higher and subtler things of the moral life that Mr. Keatinge has to speak of attempts at moral instruction as "attacks upon the boy's moral code." To deal with serious things would be to "preach," to "moralise," and to manufacture "prigs."

This horror of "priggishness" is exactly as traditional as the rest of the moral code. It is itself a witness to human plasticity; a proof that artificial maxims and artificial horrors can be implanted in boys, and can persist even into maturity and age. While commandments of the form "Thou shalt not"-_ "Don't swear," "Don't lie"are alleged to be ineffective with boys, the commandment "Don't be a prig" ("Don't ever talk about serious matters") claims absolute authority among the masters and boys of our secondary schools. Descending into our primary schools, it brings an aroma of philosophic profundity, and even, at times, distant suggestions of the repose that marks the caste of Vere de Vere. "The commandment 'Don't be a prig' has almost taken its place in the decalogue." $x$

In fact, after rejecting without trial the notion of character-building through apperception-after avoiding like the plague any attempt at direct or indirect moral instruction or suggestion-we then assert that boys are necessarily colour-blind barbarians! The effects we have produced we attribute to every cause except our own neglect. Any psychologist, armed with the apperception doctrine, could have predicted that if moral instruction, 
direct or indirect, were almost wholly absent from a school, if all attempts to present materials for the formation of the moral judgment were ostentatiously avoided, the pupils would grow up morally barbaric. The evil is a double one. The hatred of "priggishness" not only tends to deprive the curriculum of material for the formation of the moral judgment; it throws a positive stigma upon moral topics. The former evil is one of neglect; its effect is to make moral truths seem meaningless and alien. The second evil is active; it tends to render serious topics ridiculous. In short, we have not only refused to create an apperception organ for moral truth; we have done something towards creating an apperception organ for moral error. We have created "contrariant ideas" by every means in our power, and now they worry us.

But how is the original avoidance of moral instruction in secondary schools to be explained?

The Church believes in it; modern science believes in it; and, though there exist theological fears and pedagogical fears of a more or less reasonable kind, they would soon be overcome by the steady pressure of modern needs. The real obstacle is an "idol of the marketplace." Such idols trace their origin from "the associations of words and ideas." "Bacon ranks them as the most troublesome of all. 'For,' says he, 'men imagine that their reason governs words, while, in fact, words react upon the understanding." " The word "moral," in short, has been spoilt by its "associations."

Macbeth cried, on seeing the ghost of Banquo :-

"Approach thou like the rugged Russian bear, The arm'd rhinoceros, or the Hyrcan tiger; Take any shape but that, and my firm nerves Shall never tremble."

The modern educationist sees a ghost-the ghost of 
Pecksniff. When Pecksniff was born, in the second chapter of Martin Chuzzlewit, the word "moral" was doomed eternally.

"Even the worldly goods of which we have just disposed," said Mr. Pecksniff, "even cream, sugar, tea, toast, ham and eggs, even they have their moral. See how they come and go. Every pleasure is transitory. We can't even eat, long. If we indulge in harmless fluids, we get the dropsy; if in exciting fluids, we get drunk."

"Don't say we get drunk, pa," urged the eldest Miss Pecksniff.

"When I say zue, my dear," returned her father, "I mean mankind in general; the human race, considered as a body, and not as individuals. There is nothing personal in morality, my love."

When we pass from "morals" to "moral instruction" another ghost begins to vex the modern mind.

"Don't you think you must be a very wicked little child," said Miss Montflathers, who lost no opportunity of impressing moral truths upon the tender minds of the young ladies, " to be a waxwork child at all? Don't you know that it's very naughty and unfeminine, and a perversion of the properties wisely and benignantly transmitted to us, with expansive powers to be roused from their dormant state through the medium of cultivation?

In work, work, work. In work alway

Let my first years be past,

That I may give for every day

Some good account at last."

Thus any advocacy of "moral instruction," unless some other word than "moral" is employed, suggests at once that the advocate is the ill-starred offspring of Pecksniff and Montflathers. A plea for "humanistic instruction"nay, even a plea for specific instruction in "courtesy" or "patriotism"-passes muster as sound and sensible. But the word "moral" is fatal ; and the phrase "moral instruction," though standing for what in other connections is 
praised to the skies by almost every educationist, is interpreted as meaning abstract disquisition and perfunctory exhortation. "There is nothing personal in morality"; moral teaching must, therefore, be abstract, prosy, technical, Pecksniffian. The governess of a century ago "lost no opportunity of impressing moral truths upon the tender minds of her young ladies"; later moralists must necessarily follow the Montflathers' method.

And yet, by one of the most curious collocations of imaginable circumstances, the word "moral" has other and opposite, but equally fatal, associations. It is supposed to be a rival to the word "religious." Thus, while "moral instruction" is condemned by dangerous people as being dull, it is being condemned at the same time by dull people as being dangerous.

Shakespeare makes Goneril hurl this word against her conscience-stricken spouse; Sheridan trails it in the dust in order to make Joseph Surface amusing. Against this word, Puritan and anti-Puritan came to be arrayed in the strangest of alliances. Bunyan and the Puritans despised it as depreciatory of faith "-morality was but "filthy rags." Anti-Puritans despised it because, despite Calvin and Bunyan, "morality" and Puritanism seemed linked together. But the ruin of the word was complete when Dickens invented Pecksniff; so that now scarcely a play appears on the stage without the presence of some hypocrite or prig who brags of "morality," and is finally exposedPecksniff fashion - to the supreme contumely possible to melodrama. ${ }^{2}$ Time was when hypocrisy took the garb of virtue; in these days every man must pretend to be worse than he is. Unless the user of the word

- See an early part of the Pilgrim's Progress.

- When the stage wishes to typify a good clergyman he dispenses beer and tobacco, and shares in their consumption. The hypocrite never does these things. Compare the clergymen in Mr. Fenn's Convict on the Hearth and Mr. Jones's Hypocrites with the Rev. Robert Spalding (a blue-ribbonite) in The Private Secretary. 
"moral" can indubitably demonstrate his lack of atrabilious bigotry, he must be content to be linked with the sleek hypocrite and the prudish governess of Dickens; yet to parade his saving heresy or peccadillo will be but to court peril from another side. For the word "moral" is dangerous as well as dull.

The descent of this word through three hundred years is as marked as the ascent of another word now high in favour. Had an Oxford writer in Shakespeare's time pleaded the cause of "Suggestion in Education," I he would have been regarded as a pernicious Machiavellian.

Such are the obstacles which education has to encounter in England; such is the murkiness of an atmosphere amid which not only every English man, but every English child, is alleged to be capable of penetrating, unaided, to moral inferences !

Education will have to adapt itself to the situation thus established. The word "moral" being doomed as eternally as the word "pious," any proposals for increasing the influence of the school had better avoid its use." "Any shape but that!" Call a lesson a story lesson, a literature lesson, or a lesson on general knowledge, and the firm nerves of the educationist will never tremble.

In the paragraphs immediately preceding, the public and secondary school has been mainly under consideration. The reason is that the dogma of formal training constitutes the complete and distinctive creed of that school, while it constitutes only a portion of the motley creed of the primary.

x "Suggestion" generally means "temptation" in Shakespeare's plays.

"Another difficulty is that the phrase "moral instruction" is sometimes applied to a particularly acute problem, in which the conflict between passion and "mere instruction" is most pronounced. That, in the vast majority of matters to be dealt with by "moral" instruction, no conflict whatever would take place (the cases coming under the heads of ignorance, thoughtlessness, etc.) seems commonly forgotten. 
The latter has no one aim ; it is a product of diverse forces - religious, medical, utilitarian, literary. Only so far as the dogma of formal training operates in the justification of the grammar and arithmetic lessons as cultivating reason in general, in the insistence on neat writing as cultivating neatness in general, and so forth, do the above arguments apply to the primary school.

The reader may by this time have forgotten the gloomy vaticinations of Mr. Galton and Professor Pearson. The lower classes, in the belief of these writers, are swamping, by sheer weight of numbers, the class that constitutes the "backbone of the nation." Thus the "stock" of the English race is steadily deteriorating; prudence, intelligence, and other desirable qualities are being weeded out; the alleged "barbarism" of the upper and middle classes being kept in countenance by the increasing barbarism or incompetence of the lower.

If, indeed, Professor Pearson's interpretation of our social phenomena were the true one-if heredity and stock were the only factors that told in the end-the spectacle of the falling birth-rate of the middle class would be enough to fill any observer with despair. But, from the standpoint of the present essay, though the observer may have a right to lament the condition of the modern world, his lamentation should be not on account of the deteriorating stock, but of the appalling environment of large portions of the race. A child is born with a plastic, vacuous, and hungry mind; the easiest thing in the world is to give it false ideals of conduct. Yet our educational writers stand by and innocently urge that the giving of true ideals of conduct is impossible except by subtle, cautious, roundabout methods. They would hound out of a school a teacher who advised his boys to steal whiskey and drink it ; immoral instruction, immoral ideas, they admit to be dangerous ; but deliberately to array the same machinery on the side of virtue 
they allege to be bad pedagogics. That the chief function of education is the handing down to the child of the riches of the past-ethical riches among them-and that this is absolutely the only way in which modern democracy can protect itself against the swamping-out of intelligence and moral restraint-facts like these are implicitly denied by nine out of ten men who lecture or write on education.

The peril is enormous, for improvidence seems indeed to be winning a victory over providence. Yet if, as Professor Pearson alleges, the middle class is the "backbone of the nation," the reason is not the superior "stock," but the superior ideals, the more refined family life, which mark that class. The observer, comparing the lot of the boys born into the middle class with that of boys born into the lower-perhaps the slum-class, will envy the first and regret that the second start life handicapped. Sights, sounds, ideals - all are different. The observer will, nevertheless, turn with hope to educational agencies; these may do much to redress the balance against the slum-child. Great is his disappointment when he is told that the task of education is not this redressing process, but one of "drawing out" the child's powers. It was his impression that something was lacking to the child, that something had to be super-imposed-given--suppliedprovided-imparted: notably an ethical tradition, a mass of ideas and ideals; conformable to the child's nature, doubtless, and not imposed brutally, stupidly, unintelligently, but still super-imposed-given-supplied-provided-imparted.

And biological and sociological science in the main supports this view. The fabric of civilisation rests, not on heredity, but on tradition. Heredity is, indeed, omnipotent, but not the heredity in which Mr. Galton and Professor Pearson are interested. The well-nigh omnipotent thing is "social heredity"; and the main task of education is to provide it. If this is impossible-if the heredity of 
the poor is so intractably bad that no educational process can amend it-then, indeed, every man of decent stock must look with ever-growing alarm and malevolence at the increasing numbers of the poor. The middle-class family of one or two will have a right to regard as its natural enemies the lower-class family of six or eight. Mercy and charity will be crimes against the human race. On the other hand, if social heredity is the thing that counts, the situation, though grave, is not hopeless, for through our schools we can do much to ensure that the six or the eight may grow up almost as worthy and efficient as the one or the two, not eating the bread earned by their "betters," but contributing with them to the national resources.

And science assures us that, bad though the environment of the poor may be, it is almost powerless to touch an unborn generation. Except by depriving the fœtus of adequate nutriment, and in some cases by attacking its tissues with hostile fluids, the environment seems not to affect it. The foulest sights seen by the mother stamp themselves not at all upon the mind of the unborn, for "maternal impressions are not transmitted."

And, further back yet, the germ-cells of either parent, if not wholly impervious to influence, are relatively so. It would seem as if in the great scheme of things, germ-plasm and embryo were alike designedly saved from the attacks of the environment. Only the brain is plastic; and the task of education is to ensure that the trust of Nature will not be betrayed.

That there are valuable and even promising elements in English education, primary and secondary, is obvious to all. We have some fine traditions; we have materials and machinery; nay, we have men and women in proportions far more favourable to sane progress than America, with its excess of women, and Germany, with its 
excess of men. But somehow our touch, our formulæ, are wrong. There is a lack of lucidity, of adjustment, of confidence. Yet at times it would almost seem that we need, for future triumph, little more than a turn of the kaleidoscope, a rearrangement of the elements already existent in our educational system, a new orientation. In other words, though we do not need any very fundamental alterations of curriculum, we need to look at the curriculum from a new standpoint.

We shall still teach arithmetic and mathematics, but they will be kept a little nearer to human life-to modern life by the practical type of problem solved, to the past life of the race by the recognition of biographical and historical elements in arithmetic and mathematics. We shall still teach science ; but here, again, we may look upon it more largely as a record of human achievement and a presage of future achievement. Certainly we shall still teach language-even grammar: teach them far more, because far better, than in the past; but we shall no longer expect the perception of grammatical distinctions from children who cannot speak ten consecutive words, nor will there be schools where children can parse and analyse and yet know nothing of the literature of their own land. We shall still have our singing, and probably we shall have far more drawing and manual work than now. But scarcely one of the subjects will be taught for quite the same purpose as at present. A different series of categories from those handed down by the "faculty" psychologists will dominate our school work.

Shall we cultivate the "faculty" of "will" - shall we train a boy to "set his face (when need be) like a flint"? We shall ; but we shall look a little behind the "will" faculty and recognise, with Mr. A. C. Benson, that "we cannot get strenuous and zealous work unless we have also interest and belief in work." Shall we cultivate the "faculties" of reasoning, of observation, of accuracy, of 
invention, of memory, of imagination? We shall ; but here, again, we shall recognise that we can cultivate none of them successfully unless we also cultivate "interest and belief in work." Now, "interest "was Herbart's central category; and as "interest" is linked with "apperception," and "apperception" is impossible without "apperception masses"; and as "apperception masses" are no other than groups of ideas, and ideas are the constituents of knowledge; we shall entirely reject the dogma that the giving of knowledge is " not the teacher's business." We shall regard it as his chief business. School methods will be such that the pupil will acquire real knowledge in abundance-sometimes directly from the teacher, sometimes through organised private study partaking of the nature of research. The value of good habits and the perils of bad will not be forgotten; but the falsity of the view that by habit-forming, apart from any conscious realisation of the significance of habits, a nation can be rendered moral, will be recognised by all.

Our motto will be, "Let youth but know." An anonymous and eloquent writer has recently pleaded in those words for a curriculum conceived on Herbartian lines. He nowhere refers to Herbart, and yet "Kappa's" plea is that character is linked with interest, and interest with knowledge, and that the first task of education should, therefore, be to give to the pupils of our schools an "æsthetic revelation of the universe."

Let Youth But Know is a plea for an education that will open the mind of the modern boy to the two worlds of Nature and Human Nature. It was written because "Kappa" had come into contact with a youth who, despite a distinguished career in an English public school, remained devoid of "apperceptive interest," owing to the predominance in that school of the dogma of formal training. "His irrecoverable years were being spent in moody discontent" at a great English University. 
"His days should have been as a rosary of priceless pearls, and he let them run through his fingers like beads of common glass. Why? Clearly in ignorance.......Fate had given him a treasure-casket, but no key to unlock it ; and education, failing in its primary duty, had not helped him to forge a key....... Why should not youth know? Why should its best years be portioned out between dead task-work and idle child's play, both seeming deliberately calculated to conceal from it the splendour and the mystery of this strange adventure of life, on which, for a little while, it is embarked? We are given some two or threescore years to enjoy the pageant of the universe and contemplate the miracle of existence; and we let our ingenuous youth waste their intelligence on dismal pedantries and their admiration on despicable trifles. Is it so surprising, after all, that my young friend should move as a blind man among the 'glories of his blood and state'?"

All which, in Herbartian terms, means that the hapless youth possessed no "interest" in the things of nature or the things of man; owing to his lack of knowledge-of apperceptive resources-he had no "key to unlock his treasure-casket." $\mathrm{He}$ had been "trained," it is true, in the approved methods of the English public school; but the "training" had failed for exactly the reason given by Herbartians : it had been "formal" training.

"He moved every day among noble buildings, pregnant with historical and personal associations; and he did not care to inform himself of them. Knowing practically nothing of the political or spiritual history of his country, he was naturally indifferent to the part which Oxbridge had played in it....... His school life had left him with an unawakened imagination, an atrophied intelligence, a patriotism undistinguishable from the most primitive tribal instinct, and not the remotest realisation of his heritage." While "absorbed in childish things" he was 
"obtuse to the glories, privileges, and potentialities of life," "blind to the splendours of his environment." Such obtuseness, such blindness, was no exceptional state; it was "absolutely normal" among English youths; "a cataract which education scarcely attempts and, in most cases, wholly fails to remove."

Which, again interpreted, means that the English youth described by "Kappa" had been deprived of apperceptive interest by being deprived of ideas. And the reader may well note that though this youth had been trained on classics-a study supposed to "fortify the mind"-and had become the head boy of his form, he possessed an "atrophied intelligence."

And the writer of Let Youth But Knowv, looking about him for symbols of the finally important things in education, bethought him of the Palace of Aladdin and the Adventures of Sinbad; the wonders of the physical world and the records of humanity. It was the task of education to make these known. "We move in the midst of a stupendous fairy tale, compared with which the most fantastic Arabian Night is humdrum and pedestrian. What was Aladdin's Palace to the dome of the million jewels which is nightly builded over our heads, marvellous to the eye, but incomparably more marvellous to the mind? What were the Adventures of Sinbad compared with the toils and vicissitudes, the triumphs and defeats, of our fathers and our brothers, the race of man on earth? We are compassed about with glories and mysteries, and we feed our children's souls on Greek accents and bowling averages!"

Which, again translated into Herbartian language, means that modern education fails to give, because it never seeks to give (having other ideals and categories), an æsthetic presentation of the universe; fails to awaken an interest in nature and in human nature, in the physical universe and the records of humanity. Education may babble of cultivating "observation," of cultivating 
" reason," of cultivating "will" or "effort." But the false "faculty" theory that underlies these attempts foredooms them to failure. Our pupils do not "observe," do not "reason," and are not trained to "effort." The three mills produce nothing, for they are treadmills. ${ }^{\text {I }}$

Now it is from schools that produced the youth of "Kappa's" narrative that the strongest protests against moral instruction come. Masters who pin their faith to a false dogma - that of "formal training"-and scarcely recognise, even casually or indirectly, the importance of a true one-that of apperceptive interest-are the men who, with a unanimity that is proof in itself of the power of education, declare that character-forming through the agency of ideas is impossible. Their competence to deal with any new or important educational proposal is therefore the reverse of obvious. They are good men-they are probably good schoolmasters-but as pedagogical authorities they have no recognisable status at all. There are difficulties in the way of moral instruction; there are experiments to be tried and methods to be learnt; but from critics who insist that instruction is the least important part of the work of a school, light upon the special problem of moral instruction is scarcely likely to come.

There is one final and whispered protest. "You have ignored individuality" will be said by the reader who, with increasing annoyance, has come to these closing paragraphs. There is reason to believe, on the other hand, that the cause of individuality, so far as it is the cause of a fact, and not of a fiction, can best be served by the means already suggested. The fierce protests against the past failures of education have no bearing now that

"It may be advisable to say that a "classical" education, conceived on truly humanistic lines, would be open to none of the objections above suggested. The trouble has been that the classics have been used as a purely formal gymnastic. 
we know, almost beyond dispute, that a false dogma was dominating educational method. "Formal training" may have crushed individuality, or failed to nourish it ; a living and many-sided curriculum will give it a chance.

It is doubtful, however, whether the notion of individuality is so important as commonly supposed, or at any rate so fundamental. Of all individualities, the writer knows only one with any intimacy; it consists of certain ideas once received. Most of these ideas can be traced-some to a puritan source, some to Matthew Arnold, the rest to Herbart. And when the pages of James's Psychology are opened, the reader will find that the "self" consists of a circle of thought, and that any other meaning is too elusive to be useful. "Self" and "individuality" mean much the same, and, like " heredity," mean so little of a helpful kind that a wise educational philosophy will, for the present, leave them alone.

Readers of Dewey, Stanley Hall, and others of the American school, will nevertheless urge that the curriculum should be adapted year by year to the changing needs of the child, so that the vague and fleeting instincts appearing at each period may receive nutriment appropriate to themselves. On reading such a work as Adolescence, one begins to realise that our essays and treatises on education are little more than the empty chatterings of ignorant men. The problem demands a colossal intellect, and we are pigmies. Nevertheless, a system of education adequate to modern needs seems possible even if most of the subtler factors emphasised by Dr. Stanley Hall were ignored.

He sees in the child's unfolding soul traces of the longvanished epochs when the animal ancestors of man were aquatic, or amphibian, or arboreal ; and he bids us think of these traces when we choose our school studies, so that child and curriculum may be joined by links of sympathy.

It is fai from certain that Dr. Hall's interpretation is true, or that the past has engraven itself so deeply-or 
could engrave itself-on the race. But, admitting his interpretation, we admit only that there are specific plasticities; we do not deny the general plasticity of the soul. This may triumph over every factor urged by Dr. Hall. "Children are so imitative and impressionable, so open to suggestion and personal influence, that a clever teacher can direct her children's interests into almost any channel." $\quad$ The wise and economical teacher, indeed, will use the specific plasticities for educational purposes; but he will never lose sight of the great truth-the saving truth revealed to Herbart-that ideas are forces, the forces which he is called upon to employ. A finally scientific system of education will take account of every shade and type and moment of soul-plasticity ; a progressively scientific system will take account of the more obvious and important. But if it took no account of them, and, forgetting the more or less dubious details revealed by modern child-study, remembered only the broad truth that the soul is hungry, plastic, and responsive, all might be well. No great error would be possible. Inevitably and especially, the curriculum would be made rich in humanistic materials. How best to employ those materials for moral purposes the teachers of the future will ultimately learn, and then the memory of the present controversy will be consigned, along with the names of its participants, to oblivion.

I Chubb, The Teaching of English. 


\section{APPENDIX I.}

\section{SOME NOTES ON HEREDITY.}

\section{(1) Terminology.}

THE distinction between "heredity" and "variation" is not always preserved in popular discussions. We commonly say that the congenital differences between two children of the same family are due to "heredity": in point of fact, their " heredity" is the same, in the sense that their ancestors were the same back to the very beginning of time. But the children "vary." Mendel's work was to discover certain laws that underlie "variation."

Three terms are commonly used to describe it. They are distinguished, as follows, by Professor Pearson :-

Regression stands for the tendency of offspring of exceptional parents to " regress" towards the racial average. Exceptionally" tall parents are likely to have tall children, but the tallness will probably be less than that of the parents.

Reversion stands for the appearance in a child of traits not apparent in the parents, but possessed by some other members of the stock-a grandparent, for example. Mendel's researches dealt with reversion of a sort.

Atavism stands for the appearance in a child of some trait supposed to be remotely ancestral-e.g., excessive hairiness.

\section{(2) Nature v. Nurture.}

Mr. Galton (Inquiries into Human Faculty) urges that "Nature" (i.e., heredity) is demonstrably predominant over "Nurture" (i.e., education and environment), and he particularly specifies the case of twins. But is there not a fallacy in this?

Let us suppose that two children are born of the same parents, and that certain of their natural endowments are in the ratio of $1: 2$; i.e., one child is twice as capable as the other.

They go to the same school, have the same environment, etc. 
When middle-aged, they are still found to differ considerably. "The power of 'nature'!" says someone.

Or the inferior child may receive the better education, and yet remain inferior to his brother. "The power of "nature'!" is again the comment.

But this is to ignore the great mass of common acquirement which has civilised both of the children to much the same extent. If we wish to learn the real power of "nurture," we must consider two children brought up in widely different environments-e.g., one among Red Indians, the other among Europeans.

Supposing that the ratio of inherited quality is $I: 2$, children brought up in an English environment may, by middle age, be represented by the ratio $19: 20$; i.e., the difference of innate ability is as great as ever, and is noticeable at once, but the great mass of acquired motives and ideals, common to the two, is not noticed at all.

\section{(3) Mendelism.}

The question of heredity has entered on a new phase during the past ten years, owing to the unearthing of Mendel's researches on green peas. The plant again! We are to discover the laws of human nature by the study of heredity in non-conscious, nonmoral plants !'

The irony of the situation lies in the fact that the man from whom has come this new impetus to the study of heredity, and these new insights into its working, was an abbot of the Roman Church. Character, we shall be told, depends, not on baptism, not on education, but on the nature of the ancestral "chromosomes" that go to form each new being.

These chromosomes! There is no reason to doubt that they carry great secrets of heredity in their keeping. But that (apart, perhaps, from cases of imbecility, in which the features distinctive of man are absent ${ }^{2}$ ) they carry great secrets of moral heredity, that they determine men's "conscientiousness, probity," and the rest of Professor Pearson's catalogue, is highly improbable; these moral qualities seem highly complex, dependent on experience and reflection ; they are not "unit characters" in the sense of the characters considered by Mendel in his

x Some of Mr. Galton's researches were also on peas.

2 Though imbecility may not be due to chromosomatic differences. 
researches on peas. There is no question that two children of identical "heredity" - of similar "chromosomes"-might be educated into widely different moral beings by the impress of opposite ethical standards. In other words, the plasticity of the human mind is so great that no helpful comparison can be established between the "inheritance" of moral and mental qualities and Mendelian inheritance in plants, even though (as is sometimes claimed) eye colour and other human characteristics follow Mendelian laws.

It would be useless to attempt the extremely difficult task of expounding the Mendelian laws in a few words. Perhaps their (apparently) utter inapplicability to moral matters may best be shown by taking one or two of the qualities mentioned by Professor Pearson, and assuming that they follow those laws. Take "conscientiousness."

Now, Mendel has shown that his "character units" (allelomorphs) go in pairs, and that one member of each pair is "dominant" and the other "recessive" in the offspring. Let us suppose that "conscientiousness" is a dominant, and "unconscientiousness" a recessive, character. Then the offspring of two parents, one conscientious and the other not, would be divisible (if human births followed Mendelian laws) into three groups, with the numerical ratio of $\mathbf{1}: \mathbf{1}: 2$. The first group would be conscientious, the second unconscientious; the third would be apparently conscientious (owing to conscientiousness being "dominant" over unconscientiousness), but would really be of a hybrid nature-a fact which would show itself in the offspring of the next generation. If, however, conscientiousness were " recessive," the third group, though really moral hybrids, would be apparently unconscientious.

Another Mendelian law is that the various pairs of unit characters are inherited independently of each other. Let us assume that "assertiveness" (taken from Professor Pearson's list) is an allelomorph, with "diffidence" for its colleague. Then these qualities will be inherited in the same ratio as above; but they will be inherited independently of the other allelomorphs. Thus, "assertiveness" might in one case go along with conscientiousness, in another case along with unconscientiousness, and in a third with pseudo-conscientiousness.

No attempt is here being made to ridicule Mendel's 
achievement, which is probably one of the greatest in the long history of science, but to show that "virtues" can scarcely be regarded as "unit characters" (allelomorphs). Yet the essence of Mendelism is the assumption of these unit characters. By giving a name like "conscientiousness" to a series of subtle and complex phenomena, we do not establish the existence of a "unit character" amenable to statistics. Mr. Wells raises the same objection to the Galtonian categories, "ability," "capacity," "beauty," etc. ${ }^{\text {" }}$

The probability is that parents and school-teachers, by observations of their own on children, can get far nearer to a solution of the heredity tangle, so far as it bears on human nature, than the Mendelians by their researches on plants and animals.

To those who object to Herbart's way of stressing ideas as if they were atoms or units, it may be pointed out that Mendelian (and also Galtonian) views, applied to human character, are open to a very similar objection. "We seem to inherit, bit by bit, this element from one progenitor, that from another." 2

\section{(4) What is truly hereditary in man?}

(1) Something which, for want of a better word, may roughly be called by Mr. Galton's name of "energy" is probably transmitted. Whether energy is a "moral" quality we need not decide. Again, it may not be strictly hereditary after all, but connected with nutrition. Mr. Wells is " inclined to doubt the simplicity and homogeneity even of this quality of 'energy' or ' go.' "3

(2) Something corresponding to our notions of temperament and temper is probably hereditary. It is so in animals, and Mr. Galton claims that it is so in men. ${ }^{4}$

(3) Different degrees of general "plasticity" are probably hereditary, or, at any rate, congenital. Some human beings are more educable than others. If educability is almost or completely absent, the creature is not human at all, and should be ignored in all discussions of human heredity. The significant feature of plasticity or educability is that, though hereditary, it opens up the possibility of the conquest of "heredity," in the sense of fixed instincts and tendencies.

(4) Again, there may be hereditary plasticities of a specific

${ }^{1}$ Mankind in the Making.

${ }^{2}$ Natural Inheritance.
3 Mankind in the Making.

4 Natural Inheritance. 
nature ; Mr. Galton claims that artistic inheritance follows the same laws as stature and eye-colour.' Questions like this are, however, shrouded in obscurity, owing to the influence of national tradition, environment, suggestion, etc.

(5) Certain instincts are hereditary, and it should be the purpose of education to make such use of them as is desirable ; for economy of effort, if for no other reason. But human instincts are highly plastic and dirigible.

(6) Our physical qualities are inherited from our parents (with a large margin for sundry phenomena, sometimes of a Mendelian nature, such as "skipping a generation") ; our mental and moral qualities, however, owing to our impressionability and educability, are mostly superimposed upon heredity.

It should be noted, too, that, though sundry laws of heredity may be discovered operating among "pure-bred" animals and plants (the usual objects of experiment), a highly mixed race like mankind is a very different object of study. Indeed, if everything were inherited from our ancestors, we should inherit almost all the diseases, the vices, the virtues, the religions...... that have ever taken footing on the earth.

\section{(5) Myths and Misunderstandings.}

The word "heredity" is constantly being used in a loose and misleading fashion.

If a pregnant mother "catches" a disease, and gives this to her child, this is clearly not a case of genuine heredity. The fact that the child is not yet born makes no difference. The child's disease, though congenital, is certainly not hereditary, but acquired.

Again, if defective nourishment of the mother, her indulgence in alcohol, and the like, give rise to certain defects in the child, these are not truly hereditary. Whether starvation or poisoning takes place before birth or after makes no difference to the essential nature of the process. It is a mistake, then, to regard these as cases of heredity; they are more superficial and more amenable to prevention or control.

Let the reader note that things have been attributed to heredity that may have absolutely no existence at all."

Op. cit.

'Dr. Archdall Reid's Principles of Heredity, Mr. Galton's Natural Inheritance, Mr. Wells's Mankind in the Making, and similar books, are the basis of the following remarks. 
Is there, as commonly alleged, such a thing as hereditary gout? Evidence goes to show that gout is a personal acquirement in every case, though a gouty "diathesis" or predisposition may be inherited. Yet even this predisposition is not the result of parental excesses or high living; it is not a case of the sins of the fathers being visited upon the children.

Is there hereditary phthisis or tuberculosis? "In Great Britain or Germany," says Dr. Archdall Reid, "you may observe the non-infected offspring of a thousand tuberculous patients and get no evidence of transmission." Yet a narrow chest may be hereditary, and there may be a consumptive "diathesis." If, as in "severely tainted fraternities," the mother seems to transmit the disease, this transmission may be viâ the breath, not vid heredity.

But does not phthisis (and possibly other diseases) give rise to mental instability in the offspring? There is no proof of this, though possibly a "defective constitution might expose one generation to phthisis, and result in the next in mental instability. But in that case the filial instability would not be due to the parental phthisis."

Again, the supposed cases of "maternal impressions" transmitted to the child before birth are fictitious, and better explained by coincidence than in any other way. Yet the belief in them is deeply rooted.

Is there "hereditary criminality"? Mr. H. G. Wells's protest against the assumption that the criminal is necessarily a "degenerate," a member of a fixed "criminal class," with "criminal ears," "criminal thumbs," etc., is merely one protest among many against the omnipresent worship of heredity.

Lombroso, it is true, has made out the existence of such a class, and has shown that many criminals are mattoids-not wholly sane, not wholly human. Egoism preponderates with them over altruism, as it does with animals; the criminal, indeed, is "a reversion" towards the animal.

But, on the whole, criminality is not a specific quality at all. In many cases it may be a form of courage, pride, or energyhighly dirigible by the environment. Every man might have been a criminal but for some lucky chance or some lack of courage.

"Hereditary alcoholism." Dr. Archdall Reid, whose stress is 
generally on environmental influences, believes in an inherited "drink craving." But here again there is doubt whether such a specific craving exists. Men, as Mr. Wells points out, differ in the power of their habits-some men can form none, others are slaves to them. A man of the latter type can become a hopeless dipsomaniac, and yet possess no inherited "drink craving." "Many causes and many temperaments go to the making of drunkards." As Dr. Robertson says, "alcoholism is a mere specific habit."

The following subject, however, is the most fruitful of fictions about "heredity."

(6) The alleged transmission of parental acquirements, of the effects of use and disuse, etc.

"The bubble of heredity," says Mr. Bernard Shaw, "has been pricked." But he is here clearly using the term "heredity" in a limited and unusual sense. What he means by it is the transmission of "acquirements" from parents to offspring. "The certainty that acquirements are negligible as elements in practical heredity has demolished the hopes of the educationists as well as the terrors of the degeneracy-mongers; and we know now that there is no hereditary 'governing class' any more than a hereditary hooliganisın." In other words, it is not possible, by deliberately educating one man to be a "governor," and tacitly educating another to be a "hooligan," to cause a transmission of governing power or of hooliganism to the offspring.

This is neither the usual nor the most convenient meaning of the word "heredity"; nevertheless, Mr. Shaw's statement that "the bubble of heredity has been pricked" may serve to impress the fact that there is a good deal of the mythical in our common notions.

Parental acquirements (good or ball) are almost certainly not transmitted to the offspring. A parent acquires knowledge of several sciences and languages; his offspring does not on that account acquire any additional facility for the learning of those languages; there is, at least, no proof whatever that they do. A child of English parents would pick up French as quickly as he picks up English if he is given an equal opportunity. [Bastian and others contend, however, that a general speech mechanism 
has been acquired by the race, and is transmitted by heredity; likewise that memory for words has been enormously improved among the Chinese and other Eastern races by the practice of memorisation.]

The parent comes to an immoral resolution; this does not affect, so far as we know, his germ cells, nor, consequently, the "hereditary" characteristics of his offspring. The parent "eats sour grapes," but the children's teeth are not "set on edge" in any such way. If intemperance and other vices or maladies are actually transmitted from parent to child, the mechanism must be of a different nature from this. Similarly, the "moral" resolutions of the parent do not, so far as we know, affect his offspring through a germinal medium. We constantly hear of "hereditary cricket," and so on ; but such things are probably myths.

Strength of muscle, so far as such strength is the result of exercise, is not transmitted ; nor weakness of muscle, so far as such wealkness is the result of lack of exercise. In short, the effects of "use and disuse" are not hereditary, and the various examples ${ }^{\mathrm{I}}$ supposed to prove that they are may be better explained along other lines-namely, natural selection and sexual selection.

Scars and mutilations do not seem to be transmitted, as shown by examples such as the docking of horses' tails, the compression of girls' feet in China, the practice of circumcision, etc. When mutilations are accompanied by a morbid condition there may possibly be a transmission, ${ }^{2}$ though this is far from certain. [There are, nevertheless, a few apparently authenticated cases of the transmission of mutilations; moreover, as mutilations are usually confined to a single parent, and are not repeated time upon time, they do not afford perfect evidence that mutilations of both parents through many generations would not be transmitted.]

Changed conditions of life-especially conditions of food and climate-may, however, have some influence on the germ plasm, and may therefore be transmitted. Bees, violets, etc., transferred from one region to another, show changes of colour, which changes seem to become hereditary. Changing the food of

E.g., the supposed diminution of human jaws.

2 Brown-Séquard's guinea-pigs are a case in point. 
certain caterpillars changes the colour of the sequent butterflies through several generations.

In the text of the present essay it has been assumed that "acquired characters are not transmitted," the majority of biologists inclining, though with many reservations, to that view. Supposing, however, that Lamarck, Spencer, and other biologists, were right in their belief that such transmission is possible, the significance of education would be still further increased. Indeed, some upholders of non-transmission regard the cause of education as linked with that of transmission, and see in the alleged downfall of the latter doctrine a check to the claims of education. "The certainty that acquirements are negligible as elements in practical heredity has demolished the hopes of the educationists." "The substitute (for natural selection) on which moralists and legislators rely......is the cumulative inheritance of the beneficial effects of education, training, habits, institutions, and so forth-the inheritance, in short, of acquired characters, or of the effects of use and disuse. This substitute.......is a broken reed." " Yet, needless to say, the significance of education is not destroyed by the rejection of the doctrine of use-inheritance ; for the human slate is left as plastic as ever-cleaner, indeed, than if the parent's good deeds or bad deeds impressed themselves germinally on his offspring.

If, however, the doctrine of use-inheritance were true-some biologists still believe in it - then, indeed, education, though less directly influential with the child, would indirectly be more influential and momentous than ever. By acting on the parent it would be predisposing his unborn children to a similar process; while, conversely, the degraded surroundings of the parent, predisposing his offspring to similar degradation, would call to the educationist for amendment.

- Mr. Bernard Shaw.

2W. Platt Ball, Effects of Use and Disuse. 


\section{APPENDIX II.}

\section{MR. KEATINGE'S HERBARTIANISM}

Certain remarks in the preface and in the text of this essay need amplification.

What, essentially, is Herbartianism? It is a system of thought which regards the "idea" or "presentation" as the best starting-point for educational exposition; which believes that much mental life can be interpreted in terms of ideas-their emergence, coalescence, rivalry, and so forth ; that factors like feeling and will, soul and heredity, though as primitive and fundamental as any others, are best dealt with educationally in relation to ideas or presentations ; that certain categoriesnotably "apperception" and "interest," or these in union, "apperceptive interest"-are more helpful than the categories of the faculty-psychology; that education must have a definite and ideal aim ; that this aim is "character"; that character is linked with insight and interest; that insight and interest are linked with apperception; that these things are under educational control; and so forth. On countless matters of detail the Herbartian knows as little as other educationists; he awaits the results of physiological psychology, of psychiatry, of child-study, with the same keenness as they; and he knows that his presentational mechanism is but a working hypothesis. But, pending the arrival of that more perfect system of educational doctrine at present germinating in the minds of pedagogical thinkers, but not yet revealed to the world from the chair of any British university, he sticks to his own system, interpreting it as broadly, helpfully, and practically as possible.

Now, to assert that Mr. Keatinge is essentially an Herbartian is to assert that the above standpoint is his. Let us make an anthology from the phraseology of his book.

"An idea tends to persist and to overflow into action.......after 
a considerable period of inertness;" "the energy of ordinary ideas;" "the intrinsic virility of certain ideas;" "though they may not constitute the whole mechanism, they set it in motion ;" "class-work consists, to a great extent, in placing ideas before the young ;" "impulses.......are partly conditioned by ideas ;" "introduce ideas in such a manner that they stimulate...... impulses and bring them into action ;" "impulses.......are silent and ineffective until the right idea is introduced and pulls the trigger;" "an idea by its suggestive force can determine......;" "furnishing the mind with living ideas for suggestion to work upon."

"The tendency of the idea to develop is blocked by other more powerful ideas and impulses ;" "the energy of any idea is determined less by its intrinsic nature than by its relative strength as compared with the ideas which impinge upon it;" "an idea is obstructed by......a number of prudential ideas;" "ideas on both sides of the blocked point;" "ideas with which it is competing."

"A great mass of precepts and ideas...... sink rapidly below the margin of consciousness ;" "subconscious ideas colour the ideas in consciousness ;" "set the mechanism in motion ;" "there is some mechanism ;" "an idea may be introduced marginally ;" the "energy" of the ordinary idea "depends on its filling the centre of consciousness"; " a new idea......after a period of existence as a latent idea (may) become suggestive and dominating;" "the ideas that occupy the field of consciousness form but a small part of our mental life;" "ideas may suddenly be shot up into my consciousness."

"Education to a large extent consists in organising in the mind large tracts that can function independently;" "the more efficient the mind, the more complete is the dissociation of its parts, while at the same time the firmer are the bonds by which relations of unity knit it together;" a lively and energetic idea "must be massive"; "ideas initiate trains of association ;" "a system of ideas that is easily affected by a suggestive idea ;" "centre-points for idea-systems ;" "groups of ideas ;" "a system of ideas, the greater or less complexity of which will determine the fixity of purpose ;" "a sinall idea-system is left to float......;" "a suggestive idea......must find as material to work upon groups of ideas;" "the mind possesses a large stock of meaning which is imposed upon the new ideas that are presented to it ;" 
"ideas that will produce interests ;" "certain ideas will, from their intrinsic value, tend to concentration."

"Building an ideal construction in boys' minds," which construction "exercises a control on conduct;" "ideas ultimately tend to form a character;" "ideas affect the springs of conduct;" "the teacher, in manipulating and reorganising the mental elements,.......is a creator ;" "if the teacher makes it his aim to see that the subconsciousness of his pupils is a mind of meanings,.......ready at any moment to develop into auto-suggestions,......he will be a creator of mind, a true producer of mental energy."

If the first of the above paragraphs of selections does not teach that ideas may be regarded as possessing energy, that they rise and fall, and that instruction is essentially the giving of ideas; if the second does not teach the doctrine of blocking, checking, or competing of ideas; if the third does not teach the doctrine of the threshold, the subconscious, and the mechanism of ideas; if the fourth does not teach the doctrine of apperception and interest; if the fifth (the culmination of the other four) does not teach the most undiluted Herbartianism-then there is no meaning in Herbartianism at all.

Yet, in another sense, the Herbartian terminology-unless the constant use of the word "idea" is an exception-is not very prominent in Mr. Keatinge's book. "Apperception" and "interest" sometimes occur, but not frequently. The truth is that the word "suggestion" is such a good one (its employment constituting the most valuable feature of Mr. Keatinge's book), that it renders the Herbartian terminology largely unnecessary, for suggestion always implies apperception. Still, we come across "fusion" of ideas, "massiveness" of ideas, a "mechanism" of ideas, "margin" (= Herbart's threshold), "blocking" or "checking" of ideas (= Herbart's Hemmung), and, of course, "contrariance" of ideas.

More important than its terminology is the spirit of $\mathrm{Mr}$. Keatinge's book. He believes in the creative function of education; that the law of conservation of energy is not applicable to mental processes; that "meaning may be added to meaning" (p. 153). Herbartians have said exactly the same. ${ }^{x}$ 
He holds that mere emotion has little educative value (76). Herbartians have said exactly the same." He finds a convenient starting-point for educational discussion in the facts of hypnotism. Herbartians have found the same. ${ }^{2}$ He objects to snippets (56), apparently to the dogma of formal training (67), to the faculty doctrine (107), to the practical ignoring of subjectmatter ( 176$)$; and he regards the humanistic subjects as fundamental for moral education, as by means of then " moral ideas can be introduced" (160-61).

Only in one or two points does he appear to contest the Herbartian view, and in those points his treatment is singularly lacking in power.

(1) "Apperceived ideas are not necessarily suggestive."

"The theologian may have a very clear conception of the advantages to be gained by making a successful coup on the Stock Exchange ; but he prefers to act otherwise."

Surely the "theologian" apperceives the superiority of his spiritual work over the despicable coup; while the shady City man apperceizes the superiority of the coup, or, rather, is incapable of apperceiving anything else. Mr. Keatinge's example, when analysed, is really a tribute to the significance of the apperception doctrine. That a man can fully and perfectly apperceive what is good, and yet follow the bad, is a hopeless and paralysing view, and implies that there is a permanent dualism in human nature and in the universe. As Mr. Keatinge says in another place, "the right idea is not there to pull the trigger, or......there is something that renders it ineffective"; in fact, genuine apperception is absent. Because a lower type of apperception may fail to issue in action, Mr. Keatinge advocates "suggestion"; but this is merely apperception under another name.

(2) If advertisements (of Jenkins's specifics-soap or hair restorer) are too persistent, "a feeling of reaction rises and developes within me."

$\Lambda o$, it does not, unless we have had experience of the fact that advertisements are often fraudulent, and that their fraudulence is often directly proportional to their insistence. A person new 
to modern arts of advertisement would be taken in by them at once. "Reaction" and "contrariance" are here the results of other ideas-ideas of fraud. Such ideas do not spring out of nothing, but out of experience or testimony.

No doubt, mere persistence sometimes produces tedium (not contrariance); but that has been allowed for by the Herbartians in their doctrine that apperceptive interest involves the new as well as the old-novelty as well as familiarity. Genuine "contrariance "- the presence of hostile ideas-was not awakened in the Roman mob by the mere repetition of the word "honourable" in Antony's speech ("Brutus is an honourable man "), but by the fact that such persistent iteration was unusual and suggested sarcasm. In a ritual or a song no "contrariance" would be occasioned by repetition, which might, indeed, actually increase the pleasure.

The "contrariant" ideas specified in Mr. Keatinge's first chapter ("Hypnotic Suggestion") have a definite origin; a man dislikes whiskey (p. 6), a Catholic rejects anti-Catholic suggestions (p. I3). If "contrariant ideas" arise in connection zvith moral instruction, they, too, must have an origin; the weakness of Mr. Keatinge's book is that, apart from hints of " boredom," etc., no origin is suggested. The present essay suggests one.

"An idea calls up other ideas which may be (I) contrariant, critical, and inhibitory; (2) sympathetic and furthering ;......it calls up ideas that are friendly to it, and also ideas that are hostile." This last, apparently, is "association by contrast." But the whole argument is highly doubtful. Would critical ideas ever be called up unless at some time they had been suggested by the environment? Would not a perfectly sheltered Catholic education $(e . g$.$) altogether prevent the rise of heretical$ ideas? Did the mediæval rustic doubt? Probably not, except so far as (I) the evidence of his senses seemed to contradict the Church's doctrines; $(2)$ heretics and scoffers suggested contrariant ideas.

In one place Mr. Keatinge expressly admits that all ideas must have an origin. "Ideas, like meteors, though they come out of the unknown, must have started from some given spot and under definite conditions" (p. 136). In another place he hints that the "countless sermons and addresses in school chapels" have produced "contrariance" in boys' minds. Surely 
this merely means that such sermons and addresses have been dull and unpedagogical; and the same latent assumplion runs through all Mr. Keatinge's references to school work. Teachers, he implies, are dull dogs ; so dull, indeed, that one of their best chances of exerting direct moral influence is by keeping boys at a disagreeable task long enough to make them turn with positive relief to dull moral teaching! [This is no exaggeration; $\mathrm{Mr}$. Keatinge expressly says that "even sententious disquisitions are hailed as a godsend by a boy whose one dread is that his turn (at paradigms, etc.) may come and his ignorance be exposed" (p. 171).]

Mr. Keatinge's book has been dealt with at some length because it seems to mark a change in the attitude of educationists; a more aggressive and hopeful treatment of the subject; the employment of categories that will help and not hinder education. Of course, it is a direct attack upon methods that the Church holds educationally dear; but English people will not "draw" that "moral" from it-it will be regarded as a perfectly "safe" book. It is not only "safe," but, on the whole, illuminating. Mr. Keatinge only needs to give further study to the natural history of "contrariance," and to emphasise the fact that even "auto-suggestions" were once in the focus of consciousness. 



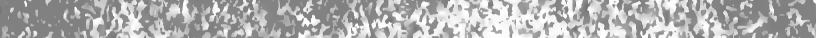

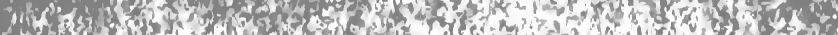

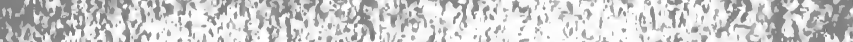

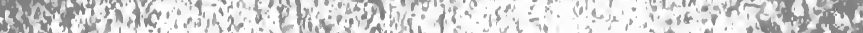

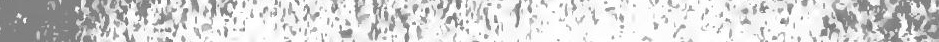

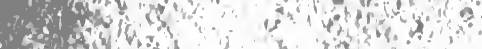
ald

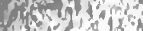

$i, 3$

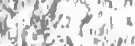
of

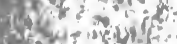

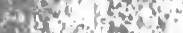

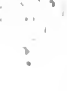





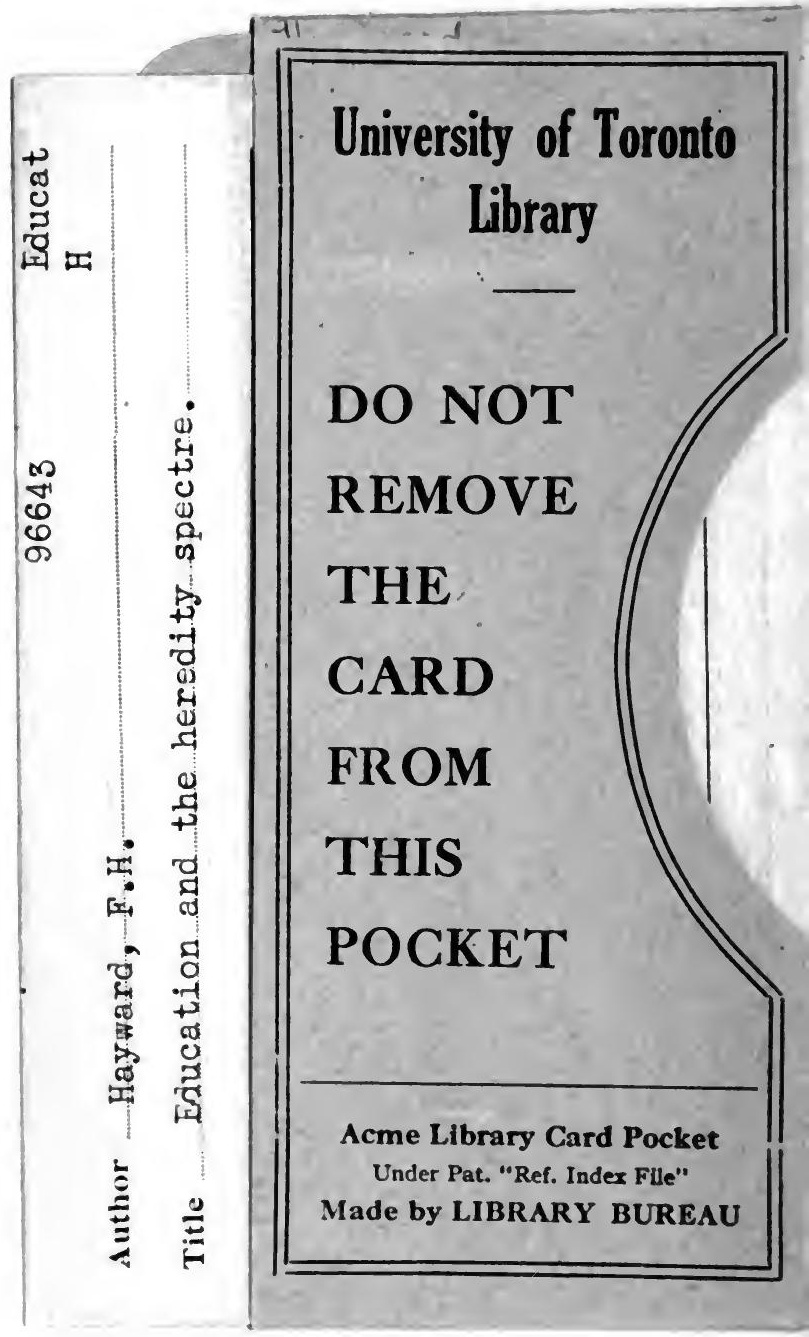


